JUDITH ZUQUIM

INFÂNCIA E CRIME NA HISTÓRIA DA PSICOLOGIA NO BRASIL:

UM ESTUDO DE CATEGORIAS PSICOLÓGICAS NA CONSTRUÇÃO HISTÓRICA DA INFÂNCIA CRIMINALIZADA NA PRIMEIRA REPÚBLICA

Tese apresentada ao Instituto de Psicologia da Universidade de São Paulo como parte dos requisitos para obtenção do grau de Doutor em Psicologia.

Área de concentração: Psicologia Escolar e do Desenvolvimento Humano

Orientadora: Profa. Dra. Iray Carone

São Paulo

2001 
Ficha catalográfica preparada pelo Serviço de Biblioteca e Documentação do Instituto de Psicologia da USP

Zuquim, J.

Infância e crime na história da psicologia no Brasil: um estudo de categorias psicológicas na construção histórica da infância criminalizada na primeira república. - São Paulo, s.n., 2001. - 216p.

Tese (doutorado) - Instituto de Psicologia da Universidade de São Paulo. Departamento de Psicologia da Aprendizagem, do Desenvolvimento e da Personalidade.

Orientadora: Iray Carone.

1. História da psicologia - Brasil 2. Infância 3. Crime 4.História - Brasil I. Título. 


\title{
INFÂNCIA E CRIME NA HISTÓRIA DA PSICOLOGIA NO BRASIL: UM ESTUDO DE CATEGORIAS PSICOLÓGICAS NA CONSTRUÇÃO HISTÓRICA DA INFÂNCIA CRIMINALIZADA NA PRIMEIRA REPÚBLICA
}

\author{
JUDITH ZUQUIM
}

BANCA EXAMINADORA

(Nome e Assinatura)

(Nome e Assinatura)

(Nome e Assinatura)

(Nome e Assinatura)

(Nome e Assinatura) 
"Por que você não fez uma tese sobre sexo?" Hannah, 11 anos

"Por que você não fez uma tese sobre coelhos?" Haline, 8 anos "Só não gostei que o título não é 'tubarões"' Nick, 6 anos 
"A imputabilidade é uma relação psicológica e ética. (...) Como elevar-se a psicologia à altura de ciência, banindo toda e qualquer lei reguladora da vontade? Quem já viu ciência sem leis? (...) Não existindo delito fora da causalidade psicológica, ninguém seria completamente imputável".

Tito dos Passos Rosas Filho, Recife 1895 In: Da responsabilidade dos menores. Dissertações e Theses apresentadas á Faculdade de Direito

"A psicologia não é a ciência fácil que todo o mundo pensa conhecer profundamente, dizendo os pretensiosos que nasceram com a boca de psicólogos tão fácil se Ihes afigura conhecer os meandros mais obscuros da alma de seus seme-lhantes. A psicologia é uma ciência dessas que qualquer charlatão se diz conhece-dor".

Noé Azevedo, São Paulo 1920 In: Dos tribunaes especiaes para menores delinquentes e como podem ser creados entre nós Teses para obter o grau de doutor em ciências sociais e jurídicas. 


\section{SUMÁRIO}

Lista de figuras $\quad$ vi

Resumo vii

Abstract viii

Introdução 1

Parte I-Objeto e método

1 A construção do objeto da pesquisa 08

2 Por uma história crítica da psicologia 19

3 Historiografia da psicologia na periferia do capitalismo 25

4 Da demência à infância anormal: emergência histórica da infância patologizada 36

Parte II - Categorias psicológicas na construção histórica da infância criminalizada

1 Crianças que trabalham e crianças histéricas $\quad 50$

2 Discernimento e recapitulação: a psicologia criminal contra a 'psicolástica' $\quad 72$

3 Impulsividade e precocidade: a psicologia mórbida das raças 81

4 Inteligência e perversidade no estrago da alma infantil:

$\begin{array}{ll}\text { a psicologia classificatória na ortopedia moral } & 101\end{array}$

5 Caráter e imoralidade: a psicologia nos tribunais de almas vacilantes 119

6 Psicomoral e ineducabilidade: os pequenos psicopatas 139

7 Hospital e prisão, escola e trabalho 165

$\begin{array}{ll}\text { Fontes e Referências Bibliográficas } & 185\end{array}$ 


\section{LISTA DE FIGURAS}

\section{Observação: somente no original.}

Capa: crianças em uniforme do Instituto Disciplinar. Fotografia publicada em MOTTA, Candido Nogueira da. Os menores delinquentes e o seu tratamento no Estado de São Paulo. São Paulo, Diário Oficial, 1909.

Figuras 1, 2 e 3: p.

Grupos de crianças diagnosticadas com debilidade mental, imbecilidade e idiotia. Fotografias publicadas em ROUBINOVITCH, Jacques. Alienénés et anormaux. Paris, Feliz Alcan, 1910.

Figuras 4, 5, 6 e 7: $p$.

Atividades no Instituto Disciplinar: trabalhos no campo, ginástica, escola e exercícios militares. Fotografias publicadas em MOTTA, Candido Nogueira da. Os menores delinquentes e o seu tratamento no Estado de São Paulo. São Paulo, Diário Oficial, 1909.

Figuras 8 e 9: páginas

Escola Pacheco e Silva, secção de menores anormaes do Hospital de Juquery. Fotografia da fachada e planta publicadas em BAPTISTA, Vicente. Escola Pacheco e Silva. Relatório apresentado ao Dr. Diretor do Hospital de Juquery. In: Pediatria Pratica. v.IV.

janeiro/fevereiro, 1932. 


\section{RESUMO}

ZUQUIM, Judith. Infância e crime na história da psicologia no Brasil: Uma análise de categorias psicológicas na construção histórica da infância criminalizada na Primeira República. São Paulo, 2001. 216p. Tese (Doutorado). Instituto de Psicologia, Universidade de São Paulo.

Esta pesquisa busca traçar as rotas pelas quais deu-se a incorporação de categorias psicológicas na construção histórica da infância criminalizada no caso brasileiro. Ao reconstruir este percurso, defende-se a tese de que a emergência de determinados saberes psicológicos no Brasil foi estruturante nessa construção no período analisado, que compreende a Primeira República. Sob essa premissa, é analisado o lugar de categorias psicológicas na constelação que demarcou o discurso sobre a infância criminalizada, pretendendo-se assim apontar marcas da sedimentação de tais categorias. Para tanto, foi necessário investigar como o controle social de numerosas crianças gerou uma norma própria ao grupo classificado como objeto de ciência. A pesquisa indicou que o objeto "infância criminalizada" não é unívoco ao ser delineado nas sentenças jurídicas, nas medidas policiais, no diagnóstico psiquiátrico ou nos projetos pedagógicos. Procurou-se descrever a dispersão desses objetos durante a Primeira República, apreender os interstícios que os distinguem e apontar o jogo múltiplo de categorias psicológicas nessa dispersão. Nesse rumo, procurou-se também enfatizar em que medida o discurso psicológico foi permeável a opções filosóficas ou morais, e atravessado radicalmente pela prática política. 


\begin{abstract}
ZUQUIM, Judith. Childhood and crime in the History of Psychology in Brazil: An analysis of psychological categories in the historical construction of criminalized childhood in the First Republic. São Paulo, 2001, 216p. Doctoral Dissertation. Instituto de Psicologia, Universidade de São Paulo.
\end{abstract}

This research traces the routes through which psychological categories were incorporated into the historical construction of criminalized childhood, in Brazil. In this reconstruction, it is supported that the emergence of certain psychological knowledge in Brazil has served as a frame for the mentioned building in the First Republic. It is analyzed the role of psychological categories in the constellation that has circumscribed the discourse on criminalized childhood. We intended, in this way, to delineate the marks of sedimentation of such categories. In order to achieve that goal, it was necessary to investigate how the social control of numerous children, covering the same age ranges, originated a proper rule to the group classified as a scientific object. The research indicated that the meaning of the "criminalized childhood" object is not the same when outlined in legal sentences, police measures, psychiatric diagnosis or pedagogical projects. It was necessary to describe the scattering of such objects during the First Republic, to grasp with the interstices that distinguish them and to point out the multiple game of psychological categories in that scattering. Following this thread, we also try to stress in which way psychological discourse was exposed to philosophical or moral options and radically crossed by political practice. 
Nota preliminar: No trabalho aqui apresentado optou-se por referências bibliográficas que indicam autor, obra e ano em notas de rodapé, para facilitar a identificação das fontes. As demais informações bibliográficas para cada referência podem ser encontradas ao final do texto. A grafia das citações foi atualizada, a não ser em casos em que a atualização operaria uma mudança de sentido, como por exemplo nevrose e neurose. 
A pesquisa aqui apresentada contou com bolsa do CNPq (julho de 1996 a junho de 2000) 


\section{Introdução}

Desde a segunda metade do século 19 os homens de ciência tentaram delimitar as fronteiras do grupo disperso constituído por crianças que cometem crimes. Digo disperso porque as "explicações científicas" para o crime cometido na infância não foram privilégio de uma disciplina em particular, mas efeito de uma sobreposição de formações discursivas com diferentes árvores de derivação, como a medicina e a criminologia. Este grupo de crianças, que chamarei aqui de infância criminalizada, foi o alvo de um pretensioso programa de reformas que passou a incluí-la em políticas públicas, ao mesmo tempo em que operou sua exclusão da família e da escola. Na base deste programa, houve uma reconceitualização da relação entre criança, família e Estado, demarcando-se assim novas fronteiras para o território da "ineducabilidade social". Enquanto nos Estados Unidos a implantação de um sistema de justiça específico para crianças esteve associada às reformas da 
Progressive Era, ${ }^{1}$ no Brasil o primeiro momento dessa construção histórica coincidiu com as expectativas de uma recém-criada república e sua diversidade de previsões para o país - em sua maioria fatalistas, racistas ou racialistas - após gerações na escravidão. O núcleo central constituidor do discurso sobre a infância criminalizada estava no que poderíamos chamar de "infância moralmente abandonada", termo disparador de uma rede de tipos infantis. Esquadrinhava-se assim o segmento social apontado pelas elites filantrópicas como a "infância em perigo", que deveria ser isolada e salva da então chamada "infância perigosa". Diante de seu novo objeto de ciência - crianças criminosas, ou infância criminalizada, entendida como um subtipo da infância "anormal" - homens de ciência, principalmente juristas e médicos, recorreram a inventivas classificações para nomear aquilo que acreditavam ser o resultado de uma falha fatal no processo evolutivo, entendido sob o paradigma da recente ciência biológica, que pouco a pouco revelava ter como objeto não mais os vegetais e os animais como classes entre os corpos da natureza, mas o ser vivo. ${ }^{2}$ Em poucas décadas, "degeneração" substituiu "evolução" na metáfora da hora.

Sob o nome genérico de "infância anormal" eram incluídas as assim chamadas crianças cegas, surdo-mudas, idiotas, cretinas, imbecis, epiléticas, histéricas, paralíticas, hemiplégicas, imbecis morais, portadoras de perversões dos instintos, retardadas, débeis, instáveis, desequilibradas, indiciplinadas, ingovernáveis. Crianças que cometiam crimes poderiam ser incluídas em qualquer classificação a partir da segunda metade desta escala.

\footnotetext{
${ }^{1}$ Sobre a implantação do sistema de juvenile justice nos Estados Unidos, ver PLATT, Anthony M. The child savers. The invention of delinquency, 1977.

${ }^{2}$ Conforme JACOB, F. La Logique du vivant, une histoire de l'hérédité, 1970.
} 
Segundo levantamentos produzidos pelo governo francês na primeira década do século XX, cerca de $75 \%$ dessas crianças poderiam ser consideradas “imperfectíveis e inutilizáveis": “chama-se criança anormal [enfant anormal] aquela que é 'totalmente diferente' [tout autre], que não se parece, do ponto de vista de suas faculdades intelectuais e morais a uma criança de seu meio, de sua educação e de sua raça. Ora, uma criança anormal que é 'totalmente diferente' é como um pequeno alienado, no sentido estrito da palavra latina alienus, que quer dizer 'diferente'. E de fato, muitas crianças anormais tem nelas os germes da loucura que se desenvolve mais tarde, se as circunstâncias são favoráveis", ${ }^{3}$ esclarece o médicochefe de Bicètre.

Desde a primeira metade do século XIX, teóricos sustentavam que a atitude criminosa durante a infância e a juventude era hereditária, e portanto uma patologia incurável à qual as "classes baixas" da sociedade eram particularmente suscetíveis. Este argumento da predisposição ao comportamento anti-social seguiu-se a uma virada nas concepções sobre a "mente" da criança. Não entendida mais como a tábula rasa imaginada no século anterior, a criança passou a ser considerada como "deficiente na vida simbólica". ${ }^{4}$ A partir do final do século, são associadas à hereditariedade outras determinantes prévias ao nascimento. Aqueles que se ocupavam das crianças criminosas pareciam constatar que a condição social à qual pertenciam tinha um papel decisivo na produção de anomalias, podendo levar ao ato criminoso. Estatísticas realizadas pelas polícias só poderiam demonstrar que um número muito maior de crianças criminosas estava entre os pobres. Reafirmáva-se

\footnotetext{
${ }^{3}$ Conforme ROUBINOVITCH, J. Alienés e anormaux, 1912, capítulo 1.

${ }^{4} \mathrm{Na}$ França, esse processo foi pesquisado por TOTH, Stephen. "Desire and the delinquent: juvenile crime and deviance in fin-de-siècle French crimilogy”, 1997.
} 
que entre ricos, sobretudo entre aqueles cuja fortuna datasse de várias gerações, as crianças anormais seriam infinitamente mais raras.

Esta pesquisa busca traçar as rotas pelas quais deu-se a incorporação de categorias psicológicas na construção histórica da infância criminalizada no caso brasileiro. Ao reconstruir este percurso, defende-se a tese de que a emergência de determinados saberes psicológicos no Brasil foi estruturante nessa construção no período analisado, que compreende a Primeira República. Sob essa premissa, analisaremos o lugar de categorias psicológicas na constelação que demarcou o discurso sobre a infância criminalizada, pretendendo-se assim localizar marcas da sedimentação de tais categorias. Para tanto, investigaremos como o controle social de numerosas crianças cobrindo as mesmas faixas etárias gerou uma norma própria ao grupo classificado como objeto de ciência.

A pesquisa aqui apresentada tem como pressuposto que o objeto "infância criminalizada" não é unívoco ao ser delineado nas sentenças jurídicas, nas medidas policiais, no diagnóstico psiquiátrico ou nos projetos pedagógicos. Procurou-se descrever a dispersão desses objetos durante a Primeira República, apreender os interstícios que os distinguem e apontar o jogo múltiplo de categorias psicológicas nessa dispersão. Nesse rumo, buscou-se também enfatizar em que medida o discurso psicológico foi permeável a opções filosóficas ou morais, e atravessado radicalmente pela prática política.

A criança que emerge desse discurso criminológico é resultado de uma reavaliação do que se poderia chamar de "instintos" infantis. Trata-se de uma época marcada por uma efervescência de modelos observacionais de estudo da criança 
com foco científico no papel do ambiente (aqui no sentido de environment) em seu desenvolvimento. A marca cada vez mais incisiva de categorias psicológicas na construção histórica da infância criminalizada relaciona-se à formação de um sistema de pensamento sobre a infância já distante das explicações apenas informadas pela moral, descolada das categorias biológicas que marcaram a primeira metade do século XIX. A esse processo corresponde uma guinada de explicações sobre o crime para o estudo da psicologia do criminoso; o alvo do discurso científico passa do crime ao indivíduo criminoso. No caso das crianças, a necessidade de teorias que explicassem o criminoso "precoce" surgem paralelamente e como efeito avesso das diversas teorias de desenvolvimento, como veremos, inspiradas em

grande parte por leituras de teses evolucionistas realizadas no Brasil preocupadas com as consequências impostas pela vida nos centros urbanos emergentes como São Paulo.

São esses balizamentos que conferem às categorias psicológicas um papel estruturante na construção histórica desse discurso, o que parecerá paradoxal para os que entendem a história da psicologia como uma caminhada marcada por descobertas sucessivas. A própria montagem da pesquisa aqui empreendida procura construir uma resposta a esse aparente paradoxo, tendo como chave a análise de categorias psicológicas compartilhadas com outros campos, principalmente o discurso jurídico. Justamente pelo fato da psicologia no Brasil ter seu processo de constituição como campo autônomo marcado pela descontinuidade, é possível supor que este compartilhamento com outros campos tenha sido uma de suas primeiras 
marcas de especificidade, oferecendo assim ao trabalho historiográfico um sítio promissor para investigações.

Paralelamente às teorias que tratam de questões ligadas à criança no processo de escolarização, que marcam o primeiro reduto "profissionalizante" para a psicologia, surgem também teorias que se referem ao que poderíamos chamar de "aprendizagem do social", em que categorias como impulsividade, perversidade e imoralidade são apresentadas como chaves para a explicação da psicologia do pequeno criminoso. À criança excluída da escolarização, que não aprende o que se ensina na escola por "falha psicofisiológica", corresponde a criança que não aprende as regras do social. Para esta, foi estruturado um discurso psicológico próprio, como pretendemos mostrar na construção da pesquisa.

No caso da infância criminalizada, é decisiva para o âmbito da pesquisa a indefinição de fronteiras que cercam tal objeto para o discurso científico. O discurso sobre a infância criminalizada constitui-se mais em torno desse temível objeto do que como construção de uma ciência em particular, fosse ela legitimada ou não. A criança que cometia crimes era apontada simultaneamente como um problema médico e jurídico, mas fundamentalmente era re-conhecida como questão social, configurando um problema a ser enfrentado pelo Estado. Particularmente revelador desse aspecto de intervenção é a discussão em torno das "crianças difíceis" [enfants difficiles], portadoras de anomalias de caráter, passageiras ou duráveis, no Brasil sinônimo de "crianças viciosas", como veremos mais adiante.

A circulação do discurso sobre a infância criminalizada ganhou proeminência no tecido social como um todo. A partir da virada do século, não só 
publicações especializadas como também a grande imprensa passou a enfocar cada vez mais a questão como um problema a ser enfrentado pelo Estado. Como será apontado, a construção histórica em torno desse novo objeto de ciência não foi constituída de um progressivo refinamento da pesquisa ou de teorias científicas. Sua emergência e seu desenvolvimento exigiram o arranjo de espaços institucionais e a legitimação do mandato de uma série de formas de fazer-ciência emergentes.

Propõe-se, portanto, a inserção desta pesquisa em um campo de trabalho que desenvolva estudos que situem a psicologia no Brasil, buscando a especificidade da construção histórica desse corpo de conhecimentos e práticas. Esta pesquisa parte do pressuposto de que a história da psicologia no Brasil deve ser focalizada não a partir de modelos importados, pois corre o risco de ser filtrada por um instrumento construído com uma escala que não lhe é própria, mas sim conectada a uma história social da infância no país - uma história da infância que contemple diferenças de classe, grupo étnico e gênero, ${ }^{5}$ que não pressuponha abstrações ou unificações em torno desse estado temporário ao qual todos somos submetidos, no cotidiano ou na memória.

\footnotetext{
${ }^{5}$ A pesquisa aqui empreendida não trata da questão específica da prostituição, colocada pelos juristas como sendo "a face feminina da criminalidade". Sob o enfoque da "condição feminina" na Primeira República, ver RAGO, M. Os prazeres da noite. Prostituição e códigos de sexualidade em São Paulo (1890-1930), 1991. Como mostra a autora, a prostituição suscitou entre médicos, juristas e criminologistas um grande interesse a partir de meados do século XIX, mais especificamente com a definição dos códigos de conduta da mulher num momento de intenso crescimento urbano-industrial.
} 


\section{Parte I}

\section{Objeto e método}

\section{A construção do objeto da pesquisa}

A partir de um levantamento e análise de fontes primárias documentais e bibliográficas, pretende-se discutir a presença de categorias psicológicas na construção histórica do discurso sobre a infância criminalizada no Brasil. O recorte temporal escolhido aponta o final do século XIX como um momento decisivo na formação de um sistema de pensamento sobre a infância, estruturado a partir da delimitação cada vez mais rígida entre infância normal e infância anormal, ampliando-se assim a nomeação de patologias próprias à infância. Via de regra, o período 1890-1927 é apontado pela historiografia brasileira como representativo das grandes modificações na legislação no que se refere à faixa etária estabelecida para a responsabilidade penal. A periodização é assim marcada a partir da promulgação 
do Código Penal da República em 1890, que instituiu a idade de nove anos como limite mínimo para a responsabilidade penal, e tem seu fecho no ano de 1927, com a promulgação do primeiro Código de Menores brasileiro, que estabelece tratamento jurídico específico. ${ }^{6}$ No caso dessa pesquisa, procuramos construir uma periodização que revele categorias psicológicas estruturantes nas descontinuidades jurídicas, e não se paute apenas pelas mudanças na legislação que opera sobre a infância. Para tanto, retornamos às discussões prévias às transformações implantadas pelo Código Penal de 1890, bem como avançamos nas consequências trazidas pela promulgação do Código de Menores no que diz respeito à nova configuração em torno da infância criminalizada como infância anormal.

No movediço campo nomeado como infância anormal, os homens de ciência do início da República no Brasil entendem a criança criminalizada como um subtipo perigoso e ameaçador. A construção de um discurso demarcando as fronteiras entre normalidade e anormalidade na infância foi acompanhada pela instauração de um sistema de pensamento específico que gerou instituições e políticas públicas próprias. A expressão acabada dos limites para essa demarcação pode ser apontada na formulação jurídica do Código de Menores, instituído em 1927, cujo objeto de intervenção é uma legislação específica para a "criança menor".

Esta pesquisa parte da hipótese de que, no Brasil, a construção histórica de categorias psicológicas que tinham como alvo a infância apresenta como elemento balizador um grupo específico: as crianças "menores", entendidas não só como objeto de um discurso científico, mas fundamentalmente apontadas como um

\footnotetext{
${ }^{6}$ Ver por exemplo BULCÃO, Ana Lucia E. Meninos maiores. O conflito da menoridade e maioridade no Rio de Janeiro entre 1890 e 1927, 1992.
} 
problema social a ser atacado por políticas públicas consideradas então urgentes. Até que ponto a fronteira entre normalidade e anormalidade na constituição da psicologia no Brasil esteve pautada e balizada por esse grupo de crianças considerado "perigoso" é uma questão que percorre toda a pesquisa. Pretende-se investigar como a observação de numerosas crianças cobrindo as mesmas faixas etárias poderia ter gerado uma norma própria ao grupo classificado como objeto de ciência, ou seja, em que medida determinados dados "psicológicos" estiveram ligadas às instituições criadas para esse grupo de crianças criminalizadas.

O surgimento da classificação que traz implícita uma dimensão contínua de desenvolvimento da criança, baseada em índices de crescimento e temporalidade, instaura um campo da anormalidade com padrões próprios, em que a infância criminalizada constitui um subtipo. Desenvolvimento é uma categoria psicológica chave que delimita e define a infância normal nesse momento de constituição do discurso psicológico. Para a infância criminalizada, outros termos surgem para dizer deste "desenvolvimento avesso" ou "involução". Surgem assim categorias como perversidade, principalmente a partir da dispersão do termo degeneração iniciada com a apropriação do conceito de $\mathrm{Morel}^{7}$ para além da psiquiatria, como pode ser bem observado principalmente pelo discurso dos juristas brasileiros aqui analisados.

Se a construção histórica da categoria desenvolvimento teve como eixo o discurso sobre a infância normal, para o qual foi erguida toda uma técnica própria a partir do centro agora eleito como o reino da aprendizagem - a escola -, por sua vez a infância criminalizada exigiu um aparato jurídico e instituições 'especiais' para crianças. Também aqui hierarquias etárias definem níveis classificatórios, porém a

\footnotetext{
${ }^{7}$ Sobre Morel e a psiquiatria, ver capítulo 4 da Parte I deste trabalho.
} 
escala é invertida. Vejamos o exemplo da categoria discernimento, que será trabalhada mais adiante: quanto maior o discernimento, maior a gravidade do crime cometido pela criança, maior a punição, maior a degeneração, maior a inviabilidade, menor a modificabilidade via escolarização regular.

\section{Categorias psicológicas}

A proposta desta pesquisa é, portanto, localizar e discutir categorias psicológicas na construção histórica da infância criminalizada. Entendemos aqui por categorias psicológicas as marcas de um discurso que ainda não se legitima como psicológico, mas que já traz a matriz de uma nova linguagem que se anuncia. ${ }^{8}$ A crítica do documento, portanto, não tem aqui como tarefa fundamental "decifrar" ou "interpretar", muito menos determinar seu valor expressivo. Procuramos aqui ordenar, recortar, distinguir séries e descrever relações. Quando se trata de um livro impresso, documento bastante presente nesta pesquisa, as margens jamais são nítidas: “além do título, das primeiras linhas e do ponto final, além de sua configuração interna e da forma que lhe dá autonomia, ele está preso em um sistema de remissões a outros livros, outros textos outras frases: nó em uma rede", 9 muitas vezes sem que os autores se conheçam, sem que grupos se remetam aos domínios vizinhos, e portanto relações entre enunciados ou grupos de enunciados e

\footnotetext{
${ }^{8}$ Sobre a construção histórica da linguagem psicológica, ver DANZIGER, Kurt. Naming the mind. How psychology found its language, 1997. As hipóteses aqui levantadas sobre a construção da linguagem psicológica são inspiradas nesta pesquisa.

${ }^{9}$ Em FOUCAULT, M. Arqueologia do saber, 1987, p.26.
} 
acontecimentos de uma ordem inteiramente diversa, seja técnica, econômica, social ou política.

O discurso de ciência que operou na nomeação da infância criminalizada exigiu a presença de categorias psicológicas que atuaram de forma significativa, conforme pode ser observado pela análise empreendida. Portanto, não há como deixar de ressaltar que as instituições de ciência criadas para dar conta da infância criminalizada - como as escolas correcionais, que serão analisadas neste trabalho foram campos de ação privilegiados por um corpo de saberes e práticas psicológicos em busca de legitimidade no pódio das ciências.

Esta pesquisa entende assim que as categorias psicológicas apontadas para a análise não devem necessariamente corresponder a conceitos da chamada ciência psicológica atual. Ao contrário, pretende-se apontar os deslocamentos de sentido que ocorrem ao analisarmos diferentes formações discursivas, entendidas aqui como construções históricas. Portanto, não deve causar estranheza que determinadas categorias sejam apontadas como psicológicas. O "psicológico" aqui corresponde a uma tentativa de reconstrução de sentido em uma determinada formação discursiva, e portanto não pode ser dado "a priori”. O que pretendemos mostrar é justamente a diversidade de sentidos dados ao termo "psicológico" - e também quais formas de enunciação exclui como não-psicológico - , em cada construção apontada, e como a essa diversidade correspondem diferentes construções históricas para a infância criminalizada.

Segundo o estudo realizado por Danziger, a rede moderna de categorias psicológicas data do século XVIII, pois foi apenas nesse momento que surgiu uma 
evidência de reflexão sistemática sobre termos que podem ser considerados de ordem psicológica. Entretanto, muitas categorias não existiram como categorias para a reflexão psicológica antes do século XX, e são portanto construções cuja história está amarrada com aquela da disciplina. Entretanto, uma série de outras categorias, como "emoção", são mais antigas e datam de até mesmo antes do século XVIII. Seriam, para Danziger, produto do processo histórico de reconstrução da subjetividade humana em termos psicológicos, um processo que esteve em evidência particularmente em certas partes da Europa pós-medieval, e formaram uma rede de categorias que foi empregada para conceitualizar a experiência humana.

As categorias psicológicas não podem ser entendidas, portanto, como consequência lógica de investigação empírica. $\mathrm{O}$ que dá sentido particular a um termo é o discurso do qual ele é parte. Como afirma Danziger, cada categoria está imersa em relações de distinção, oposição e subordinação em relação a outras categorias: "A psicologia desenvolveu certas teorias sobre motivação, sobre personalidade, sobre atitudes, mas a rede de categorias que marca uma realidade distinta para motivação, personalidade e atitudes foi retirada de uma comunidade de linguagem muito mais ampla da qual os psicólogos são apenas uma parte". ${ }^{10}$ Para escavar esse outro nível, para torná-lo visível, é preciso realizar uma análise dos discursos dentro dos quais as categorias psicológicas foram se constituindo, ao mesmo tempo em que se aponta essas categorias como estruturantes desses discursos. As categorias, portanto, devem ser entendidas como elementos em formações discursivas específicas, e não podem ser subordinadas à linguagem

\footnotetext{
${ }^{10}$ DANZIGER, Kurt. Naming the mind. How psychology found its language, 1997, p.8.
} 
psicológica atual. Em sua análise, o uso que Danziger faz do termo categoria aproxima-se ao que Canguilhem chamou de conceito, ${ }^{11}$ evitando-se assim os termos fenômeno ou teoria. Ao escolher o termo categoria, Danziger procurou transpor a multiplicidade indesejável de conotações e ambiguidades que o termo conceito apresenta na língua inglesa.

As categorias psicológicas em análise

As continuidades entre o discurso psicológico e formas anteriores de discurso se tornam mais remotas e duvidosas quanto mais tempo voltamos. Pesquisas indicam que, antes do século XVII, o universo de categorias disponíveis para analisar a experiência humana era rigorosamente outro em relação ao das categorias da psicologia moderna. Tendo em vista essa dimensão temporal, a investigação aqui empreendida tem início na última década do século XIX. No recorte temporal focalizado, a pesquisa demarcou cinco formações discursivas em que categorias psicológicas reordenam o campo da infância criminalizada. A cada uma corresponde uma formulação expressa em instituições 'especiais' para crianças. Podem ser assim descritas e indicam a abertura de cada novo capítulo deste trabalho:

1. À transição para a República (1889) corresponde a discussão em torno de um novo código penal, em que uma legislação de “menores” ganha força nas teorias que defendem o isolamento das crianças criminosas em

\footnotetext{
${ }^{11}$ Danziger faz referência ao trabalho realizado por Canguilhem e publicado em 1955, sobre a formação do conceito de reflexo nos séculos 17 e 18 .
} 
prisões especiais. Discernimento é uma categoria chave que aproxima crianças de loucos. Tobias Barreto defende uma "psicologia criminal" contra a 'psicolástica'.

2. A nova legislação instituída pela jovem República em 1890, que reduziu para 9 anos o limite de imputabilidade penal, formaliza a "psicologia mórbida "das raças"” para a qual impulsividade e precocidade são categorias-chave.

3. Os primeiros anos do século 20 trazem a discussão de modelos para as escolas correcionais, incluindo a apresentação em 1902 de um projeto que cria esse tipo de estabelecimento em São Paulo. Inteligência e perversidade são categorias-chave para a psicologia classificatória da "ortopedia moral" exigida pelo modelo correcional idealizado.

4. Os tribunais especiais, implantados no início dos anos 20 após anos de discussão, constituem-se como órgãos capazes de apontar as anomalias. Caráter e imoralidade são categorias-chave para explicar a criança criminosa, para quem a pena passa a ser tratamento.

5. O primeiro pavilhão para crianças construído em 1922 no Hospital de Juquery (São Paulo) passou a receber meninos vindos do Instituto Disciplinar. Psicomoral e ineducabilidade constituem assim categoriaschave para a "psycho-pediatria" aplicada aos 'pequenos psicopatas' ali internos. 
Cabe ainda uma palavra sobre a seleção das fontes. Optou-se por privilegiar textos cujo enfoque e preocupação dos autores estivesse centrado na infância criminalizada como problema social a ser solucionado por homens de ciência, como médicos, juristas e pedagogos. Cabe ressaltar que o recorte temporal escolhido pela pesquisa não aponta para os psicólogos como especialistas, principalmente quanto ao objeto em questão: crianças criminosas. Via de regra, a discussão da infância criminalizada como problema social exigia dos autores uma classificação que buscava precisar o que seria a infância anormal. Uma vez realizada a classificação, eram propostos projetos de intervenção do Estado, o que levou à análise de documentação oficial em diversos setores, como Relatórios de Presidentes de Província e Justiça, em especial relatórios de Polícia, encontrados no Arquivo Público do Estado de São Paulo. Após uma reforma realizada pela Prefeitura de Santos, foi possível localizar na Fundação Arquivo e Memória processos de menores no Fundo Fórum, apesar de pouco organizados por varas ou mesmo cronologicamente.

A busca pelas fontes exigiu levantamentos em arquivos públicos em capitais além de São Paulo, como Salvador e Recife, por serem respectivamente as mais antigas faculdade de Medicina e de Direito do país. Apesar da situação precária desses acervos, lá foi possível localizar textos que foram fundadores para a pesquisa, como os juristas Campello e Tito dos Passos Rosas em Recife e algumas teses baianas relacionadas ao tema das "crianças histéricas". Nina Rodrigues e Tobias Barreto estão entre os autores com algumas edições encontráveis em São Paulo, o que não nos tira o prazer e curiosidade de folhear suas obras no "clima" 
em que foram produzidas. Os Relatórios sobre o Hospital de Juquery assinados por Vicente Baptista foram encontrados na Faculdade de Medicina da USP, que tem uma impressionante coleção de revistas na área de Pediatria, e no próprio acervo do Hospital, onde é possível pesquisar as Estatísticas de Franco da Rocha. Relatórios de Pacheco e Silva também foram publicados na forma de livro, e estão disponíveis na Biblioteca Municipal Mario de Andrade, onde também consultei a coleção de jornais. Entre os acervos visitados em São Paulo, pode-se destacar a Biblioteca da Faculdade de Saúde Pública, onde encontrei - na seção das publicações "antigas" Relatórios do Serviço de Estatística Sanitária do Estado de São Paulo elaborados por Paula Souza e também os Arquivos da Sociedade de Medicina Legal e Criminologia de São Paulo, fundada por Franco da Rocha em 1922. A biblioteca da Faculdade de Direito da USP, no largo São Francisco só não foi mais surpreendente porque a entrada ao acervo é proibida, o que inviabiliza a localização de várias obras. Lá encontrei várias publicações francesas do início do século, além de clássicos como Evaristo de Moraes. Na Biblioteca da Faculdade de Ciências Biológicas da USP encontrei obras indisponíveis de Haeckel, algumas consultadas na Biblioteca da Faculdade de Filosofia, Letras e Ciências Humanas da Universidade. E por fim, a Biblioteca do Instituto de Psicologia da USP traz coleções quase completas de revistas, americanas, francesas e alemães que traçam um impressionante painel da história institucional da psicologia. Como herdeira de vários acervos, a Biblioteca conta ainda a história das publicações que interessaram à intelectualidade por várias décadas. 
Deve-se acrescentar ainda que a pesquisa, a partir de um levantamento e análise bibliográfica que incluiu a história social da infância, a história da psiquiatria, a história da pediatria e outros cruzamentos, busca situar o recorte escolhido em uma longa trajetória definidora da criança como objeto do discurso científico. Para tanto, será apresentada inicialmente uma versão das condições de emergência histórica das transformações da infância até a produção histórica da infância criminalizada. 


\section{Por uma história crítica da psicologia: as camadas de discurso}

Danziger propõe a investigação histórica das categorias psicológicas a partir de três camadas de discurso. ${ }^{12}$ Em cada uma dessas camadas, um conjunto específico de distinções emerge para formar uma rede específica e interconectada de categorias. Num primeiro nível, localizado no discurso moral articulado na Inglaterra do século 18 , surge uma nova constelação que envolveu mudanças no entendimento de antigas categorias como razão e paixão, sem as quais as modernas concepções de inteligência e emoção teriam permanecido literalmente impensáveis. Segundo o autor, a psicologia teria permanecido como parte de um discurso moral se não fossem suas pretensões científicas, que dependiam de uma metodologia e do uso de categorias que carregassem uma aura científica especial. A psicologia do século XX, no entanto, constitui uma nova camada de discurso, ao articular categorias originárias da biologia e não da filosofia moral. O uso psicológico se deveu à emergência da distinção entre um domínio fisiológico e psicológico, ao qual se segue a conturbada história dessa própria distinção.

\footnotetext{
${ }^{12}$ Danziger, Kurt. Naming the mind. How psychology found its language. Ver capítulo "The nature of psychological kinds, pp. 181-194.
} 
Uma terceira camada de discurso emerge com a profissionalização da psicologia e sua institucionalização como uma disciplina. Esses desenvolvimentos marcaram a criação de uma classe de especialistas cuja existência impôs novas funções à linguagem psicológica. Antes, distinções e termos psicológicos eram propriedade da linguagem comum, e seu uso foi largamente difundido em textos médicos, jurídicos ou educacionais, como podemos observar nas análises aqui realizadas. As atividades de uma classe profissional legitimada levaram à formação de uma nova camada de linguagem psicológica, parte para uso interno entre eles mesmos e parte para uso em contato com o público ou com outros grupos de especialistas. Essa nova camada foi constituída por um conjunto de termos técnicos, cada um relevante para um domínio relativamente limitado. Nessa pesquisa, contudo, o foco não será centrado nesse aspecto da nova linguagem psicológica, mas na sutil adaptação de termos para descrever domínios reformatados posteriormente pela atividade dos futuros novos profissionais. Estaremos, portanto, um passo atrás.

É somente em circunstâncias excepcionais, como quando uma nova disciplina é criada ou redefinida, que o trabalho de construção de uma categoria surge com maior possibilidade de análise crítica. A primeira parte do século XX é um período em que a psicologia se refez a si mesma, e a construção de novas categorias assim como a reformulação de antigas foi parte fundamental desse processo. Esta pesquisa tem como objeto discutir a natureza do processo pelo qual novos fenômenos deram entrada no discurso da nova disciplina. Entende-se que novos fenômenos emergem como resultado de uma maneira diferente de 
classificação e conceitualização. É mais apropriado, portanto, falar em novas construções e não descobertas.

\section{Interdiscursividade}

A análise de descrições em torno do mesmo objeto - a infância criminalizada - realizadas em discursos contemporâneos diferentes - nesse caso, do direito, da medicina e da pedagogia - exige uma análise interdiscursiva. Analisar a construção histórica da infância criminalizada leva à exigência de desvelar os modos de produção e disseminação de verdades hegemônicas no discurso social, e traçar as exclusões instauradas, já que a análise de qualquer prática discursiva opera como uma espécie de tradução dos conflitos sociais. As formações discursivas significam muito mais do que aparentam dizer, e essa potência deriva não só da riqueza semântica da linguagem mas também das regras que governam o discurso e a organização social.

Procura-se empreender aqui uma análise crítica conforme Fairclough propõe ao definir discurso a partir de uma concepção tridimensional ${ }^{13}$, a qual corresponde um método também tridimensional de análise de discurso: Discurso, e qualquer instância específica de prática discursiva, passa a ser visto então simultaneamente como 1. Um texto de linguagem, falado ou escrito; 2. Uma prática discursiva, e 3. Uma prática sócio-cultural. O método para análise do discurso inclui, portanto, descrição, interpretação e explicação da relação entre processos discursivos e

\footnotetext{
${ }^{13}$ Ver FAIRCLOUGH, N. Critical discourse analysis. The critical study of language, 1998.
} 
processos sociais, com ênfase na mediação entre prática socio-cultural e texto provocada pela prática discursiva.

Discurso passa a ser visto assim como uma esfera da hegemonia cultural, e portanto a hegemonia de uma classe ou grupo sobre a sociedade ou sobre uma parte específica dela depende de como se constitui sua capacidade de formatar práticas discursivas. A importância da hegemonia cultural na esfera do discurso está relacionada à potência ideológica de práticas discursivas. "Hegemonia, nesta esfera, também inclui, como o próprio Gramsci salientou, as relações estabelecidas entre diferentes variedades de linguagens e a emergência de um padrão dominante de variedade. A hegemonia de uma classe ou grupo sobre outro se constitui por um equilíbrio mais ou menos instável entre suas práticas discursivas constitutivas, que podem se tornar desbalanceadas e abertas para serem reestruturadas no curso da luta hegemônica". ${ }^{14}$

Tendo como premissa essa concepção tridimensional do discurso, esta pesquisa entende formação discursiva - de forma geral - como aquilo que designa os sistemas de regras que fundam a unidade de um conjunto de enunciados sóciohistoricamente circunscritos. Noção utilizada essencialmente pela escola francesa, a formação discursiva foi introduzida por Foucault ${ }^{15}$ para designar conjuntos de enunciados relacionados a um mesmo sistema de regras historicamente determinadas. Conforme Maingueneau ${ }^{16}$, Foucault procurava contornar as unidades tradicionais tais como "teoria", "ideologia" e "ciência". Foi com Pêcheux ${ }^{17}$ que essa

\footnotetext{
${ }^{14}$ Conforme FAIRCLOUGH, N. Critical discourse analysis. The critical study of language, p.95.

${ }^{15}$ FOUCAULT, M. A arqueologia do saber, 1987, ver capítulo "As regularidades discursivas".

${ }^{16}$ Ver MAINGUENEAU, D. Novas tendências em análsie do discurso, 1997.

${ }^{17}$ Sobre a concepção de discurso em Pêcheux, ver PÊCHEUX, M. O discurso: estrutura ou acontecimento, 1990.
} 
noção entrou na análise do discurso, e segundo essa vertente, toda formação social caracterizada por uma certa relação entre classes sociais implica na existência de posições políticas e ideológicas e se organizam em formações que mantêm entre si relações de antagonismo, aliança ou dominação. Essas formações ideológicas incluem uma ou várias formações discursivas interligadas que determinam o que pode e deve ser dito.

No caso desta pesquisa o que deve ser ressaltado é que, para cada formação discursiva destacada há um sentido próprio dado à infância criminalizada, e que este sentido é construido a partir de categorias psicológicas especificas em cada caso. Supõe-se assim a presença de um texto em outro, o que poderia ser caracterizado por uma análise intertextual de discurso, em que procura-se destacar relações explícitas ou implícitas que um texto mantêm com outros textos. As categorias psicológicas podem ser entendidas aqui como sendo o texto a ser buscado no discurso sobre a infância criminalizada.

Segundo essa concepção de análise crítica de discurso, é preciso definir uma formação discursiva a partir de seu interdiscurso, e não o contrário. O interdiscurso é entendido assim como "um processo de reconfiguração incessante no qual uma formação discursiva é levada a incorporar elementos pré-construídos, produzidos fora dela, com eles provocando uma redefinição e redirecionamento, suscitando, igualmente, o chamamento de seus próprios elementos para organizar sua repetição, mas também provocando, eventualmente, o apagamento, o esquecimento ou mesmo a denegação de determinados elementos". ${ }^{18}$ Portanto, a formação discursiva passa a ser entendida como o lugar de um trabalho no interdiscurso: "ela é um domínio

\footnotetext{
${ }^{18}$ MAINGUENEAU, D. Novas tendências em análise do discurso, p. 113.
} 
inconsistente, aberto e instável, e não a projeção, a expressão estabilizada da 'visão de mundo' de um grupo social". ${ }^{19}$

O objetivo de uma análise crítica de discurso nesta pesquisa é, portanto, desnaturalizar o próprio discurso sobre a infância criminalizada, o que significa mostrar as determinações múltiplas entre estruturas sociais e propriedades do discurso. Esta seria a diferença fundamental entre uma análise descritiva de discurso e uma análise crítica de discurso, conforme exposta por Fairclough. Não mais tratar o discurso como conjunto de signos, elementos significantes que remetem a conteúdos ou representações, mas como práticas que formam sistematicamente os objetos de que falam: "Certamente os discursos são feitos de signos; mas o que fazem é mais que utilizar esses signos para designar coisas. É esse mais que os torna irredutíveis à língua e ao ato de fala. É esse 'mais' que é preciso fazer aparecer e que é preciso descrever". ${ }^{20}$

\footnotetext{
${ }^{19}$ MAINGUENEAU, D. Novas tendências em análise do discurso, p. 115.

${ }^{20}$ FOUCAULT, M. A arqueologia do saber, p.56.
} 


\section{Historiografia da psicologia na periferia do capitalismo}

Por mais que surjam pesquisas, publicações e seminários, a história da psicologia no Brasil ainda é um campo periférico, desconectado do aprendizado das práticas profissionais em destaque no curso superior. Ora cercada por um imaginário de erudição filosófica sem "aplicação" ao cotidiano do psicólogo, ora como suporte para um discurso legitimador de certas práticas profissionais em detrimento de outras, a história da psicologia aparece como um campo de grandeza duvidosa, em alguns casos sem lugar na árvore de saberes das agências financiadoras do país.

Não há como negar que a posição historicamente construída das psicologias na divisão formal entre as ciências torna a questão da história uma espécie de idéia 
sem lugar próprio, que uns e outros tentam encaixar pelas brechas dos currículos, apesar de raros casos em que a disciplina tornou-se "obrigatória". Esse "encaixe" aparece na forma de um saber acessório, muitas vezes com um pé na história das ciências e outro na divisão atual do campo da psicologia.

Como campo periférico, a história da psicologia no Brasil deve em parte sua existência ao trabalho de pesquisadores relativamente isolados, e não a linhas de pesquisa estruturadas com o objetivo de criar condições ou mesmo 'escolas' de investigação construídas em torno de conjuntos documentais minimamente preservados com recursos de arquivística. Pode-se anunciar que a relativa legitimidade acadêmica da história da psicologia no Brasil está garantida paradoxalmente - pelo baixo status científico que este campo adquire diante da complexidade científica que a psicologia hoje aparenta ter.

Tendo como perspectiva a produção recente no campo da história da psicologia no Brasil, gostaria de apontar três óticas de construção que a meu ver colocam a história da psicologia nesse incômodo lugar. Na primeira ótica é apagada a questão do poder no campo científico; na segunda é negado o papel de "alta teoria" para a historiografia da psicologia; na terceira é ignorado o debate na historiografia brasileira. Cada uma das óticas apontadas não representa necessariamente o resultado da adoção de um determinado modelo historiográfico, mas sua discussão aponta para pressuposições que devem ser explicitadas diante do pluralismo metodológico no campo da história da psicologia no Brasil. 


\section{A brecha inevitável do presentismo}

Em primeiro lugar, o baixo capital científico da história da psicologia no Brasil insinua que a pesquisa nessa área tem pouca relevância para a comunidade de especialistas. Essa formulação pode estar encravada em uma crença implícita no progresso da ciência. Afinal, sob este ponto de vista, se a trajetória histórica de uma ciência representa um inegável avanço cumulativo de conhecimento, então seu passado simplesmente consiste em um desfile de uma série de modelos ultrapassados de práticas pouco evoluídas. Em decorrência desse posicionamento, a história tem sua importância na celebração do rumo a uma verdade científica que nem o mais esperto de nossos antepassados poderia imaginar.

É difícil partir desse enfoque e não realizar uma história celebrativa, já que toda a trajetória anterior só interessa no sentido de conduzir ao que se sabe hoje. Ao propor um novo paradigma, determinada comunidade científica supõe que seu passado é uma sequência de descaminhos que podem agora ser superados. Pela brecha inevitável do presentismo, toda história passa a ser história contemporânea disfarçada, conforme nos ensina Hobsbawm. ${ }^{21}$

Essa concepção de história como uma marcha vitoriosa rumo a certezas científicas criou uma forte tradição naturalizadora na historiografia da psicologia, que manteve uma confortável coexistência com outra tendência, derivada da assim chamada história das idéias. Nessa abordagem, o desenvolvimento dos especialismos na psicologia é visto a partir de parâmetros permanentes que

\footnotetext{
${ }^{21}$ HOBSBAWM, E. Sobre história, 1998.
} 
direcionaram a reflexão para um número limitado de canais definidos por pares de oposição: funcionalismo vs. estruturalismo, fisicalismo vs. mentalismo, monismo vs. dualismo. Nas análises, essas polaridades se mantêm como referenciais estruturantes, e não importa se o recorte temporal é o século 15 ou o século 19 , o Brasil ou a Bélgica. Para Danziger ${ }^{22}$, em ambos os casos, a história é essencialista, pois parte-se da premissa de que os objetos ou processos aos quais se referem os conceitos tem uma existência natural anterior ao ato do "descobrimento" que os leva a sua rotulação. Nesse caso, o naturalismo é uma variante do que algumas vezes é apontado como objetivismo. ${ }^{23}$

Categorias psicológicas em voga hoje são definidas como elementos ahistóricos. É o formato atual que molda e define uma categoria a partir de posições de poder no campo científico. No caso da história da psicologia, esse ponto torna-se crucial, já que mesmo após um século de uso especializado grande parte dos termos permanecem fortemente dependentes do ou compartilhados com o discurso nãopsicológico. Como já dissemos, a psicologia desenvolveu teorias sobre personalidade mas a rede de categorias em torno dessa construção foi produzida por uma comunidade de linguagem ampliada da qual os psicólogos são apenas uma parte.

As categorias constitutivas do discurso psicológico sempre estiveram ligadas a práticas sociais específicas. E portanto o significado dessas categorias sempre dependeu de seu uso em contextos sociais específicos. Por outro lado, os textos passam a constituir domínio público, e o interesse na contribuição pessoal de certos

\footnotetext{
${ }^{22}$ DANZIGER, K. Naming the mind. How psychology found its language, 1997.

${ }^{23}$ DANZIGER, K. 'Generative metaphor and the history of psychology.' In: Leary, D. (Ed.). Metaphors in the history of Psychology, 1990.
} 
autores (nas abordagens biográficas, por exemplo) não é fundamental para a análise do desenvolvimento histórico de um discurso público, que muitas vezes é definido e sustentado a partir de instituições criadas e monitoradas pelo Estado, conforme pretende mostrar esta pesquisa.

A linguagem psicológica deve ser estudada como parte da vida social e isso significa levar em conta seu papel político e suas consequências em cada recorte temporal a ser analisado. Categorias psicológicas têm sua dimensão política porque não são puramente descritivas, mas também normativas. Adotar uma classificação específica, e implicitamente rejeitar um conjunto de outras possíveis classificações, significa estabelecer uma dada forma de legitimar certas práticas em detrimento de outras. Invariavelmente as categorias funcionam como conduites para a transmissão de formas classificatórias e são fossilizadas em práticas institucionais.

Como afirma Bourdieu ao analisar o campo científico, "o universo puro da mais 'pura' ciência é um campo social como outro qualquer, com suas relações de força e monopólios, suas lutas e estratégias, seus interesses e lucros, mas onde todas essas invariantes revestem formas específicas". ${ }^{24}$ Ciência e política não se excluem; poder e saber constituem um enquadre incontornável na história das práticas intelectuais. E como diz Hobsbawm, os homens produzem tanto com as mãos quanto com a cabeça. ${ }^{25}$

A economia política da produção de conhecimento indica que qualquer prática investigativa é parte de um processo produtivo. Sua aplicação resulta,

${ }^{24}$ BOURDIEU, P. 'O campo científico'. In: Ortiz, R. (org.). Pierre Bourdieu, 1994 (Coleção Grandes Cientistas Sociais).

${ }^{25}$ Hobsbawm, Sobre história, p.175. Segundo o historiador, o processo real de produção não é simplesmente 'produção material da vida em si mesma' mas algo mais amplo: "Para empregar a correta formulação de Eric Wolf, é o 'conjunto complexo de relações mutuamente dependentes entre natureza, trabalho, trabalho social e organização social". 
portanto, na geração de produtos com valor. No caso da psicologia estamos falando de produtos simbólicos. ${ }^{26}$

\section{Legitimação e historiografia}

O segundo ponto que destaquei trata do papel de uma alta teoria - no sentido de Agnes Heller, ou metateoria no sentido de Jürgen Habermas - no campo da história da psicologia. Uma análise de certa historiografia da psicologia sugere que a crença no progresso não é um sentimento vago de cientistas aplicados. Ela resulta em uma concepção de história que legitima algumas práticas em detrimento de outras menos vitoriosas, uma concepção de história que darwiniza as idéias, elegendo as mais aptas a sobreviverem no mundo globalizado.

Contra essa posição legitimadora Adorno já escrevia no início de sua vida intelectual, quando explicitou seu conceito de história em uma conferência proferida em 1932 para a regional frankfurtiana da Kant Gesellschaft, intitulada "A idéia de história natural". ${ }^{27}$ Para Adorno, história deve ser entendida como conceito duplo,

\footnotetext{
${ }^{26}$ Sobre essa economia política no caso da psicologia, ver DANZIGER, K. Constructing the subject. Historical origins of psychological research, 1990. Em especial capítulo intitulado "The social construction of psychological knowledge".

${ }^{27}$ Para Adorno, os conceitos de história e natureza não são excludentes, mas mutuamente determinados. Um oferece a chave para a desmistificação do outro, e cada um deles tem duplo caráter. Natureza tem um pólo positivo, materialista, que se refere à existência concreta, mortal e transitória. Ao mesmo tempo, natureza também tem um sentido negativo, pois ela se refere ao mundo ainda não incorporado à história, ainda não penetrado pela razão, ainda fora do controle humano. Nesse sentido, a natureza é a instância mítica que está eternamente lá. Esse é o lado estático da natureza, perpetuado pelos rituais imutáveis das pessoas que se submetem à dominação. A história também tem um lado positivo e outro negativo. Adorno define o lado positivo como a práxis social dialética. É o lado em que algo novo emerge, que não é apenas pura identidade e reprodução do que já está aí. O polo negativo da história é determinado pelo fato de que a atual práxis humana
} 
mas seus pólos negativo e positivo perdem seu poder de crítica quando as condições sociais são afirmadas como naturais, sem que se aponte para seu desenvolvimento histórico, ou seja, quando o processo é essencializado, ou quando o material irracional do qual a história também é feita é colocado como mera contingência, ou ontologizado - como em Heidegger. Nos dois casos, o que opera é uma justificativa ideológica da ordem social dada. ${ }^{28}$

Terry Eagleton explicita que, para Adorno, “a ideologia é uma forma de ‘pensamento identificatório' - um estilo veladamente paranóico de racionalidade, que inexoravelmente transmuda a singularidade e a pluralidade das coisas num mero simulacro dela mesma, ou as expulsa para fora de suas fronteiras, num ato de exclusão tomado de pânico". ${ }^{29}$ A ideologia homogeneiza o mundo, igualando de forma espúria fenômenos distintos. A palavra progresso não deve ser aplicada, pois para Adorno o presente não recebe seu sentido da história; ao contrário, a história recebe seu sentido do presente, como um maestro ao dar som a uma partitura.

Como herdeira da tradição marxista, a concepção de história em Adorno tem em Marx a base da explicação histórica mas não a explicação histórica em si. $^{30}$ Hoje, a história marxista toma Marx como ponto de partida, e não ponto de chegada, no sentido que Agnes Heller dá à 'alta teoria'. Os princípios organizativos, explicativos e orientativos da historiografia tem sua origem em uma determinada

não é histórica, mas sim mera reprodução de condições e relações de classe, sem estabelecer nenhuma ordem qualitativamente nova.

${ }^{28}$ Sobre o conceito de história em Adorno ver BUCK-MORSS, Susan. The origin of negative dialectics, 1977. Em especial o capítulo 3: "Dialectics without identity: the idea of natural history".

${ }^{29}$ EAGLETON, T. 'A ideologia e suas vicissitudes no marxismo ocidental'. In: ZIZEK, S. (org.) Um mapa da ideologia, 1996, p.201.

${ }^{30}$ HOBSBAWM, E. Sobre História, em especial o capítulo "Marx e a história". 
concepção de mundo, ou seja, em uma 'alta teoria' ${ }^{31}$ Segundo Heller, historiadores que aceitam altas teorias diferentes, podem às vezes aplicar princípios similares, por exemplo a mesma periodização, mas sua organização será diversa. Se a organização dos princípios é fundamentalmente a mesma, as altas teorias são fundamentalmente as mesmas. As altas teorias nunca são teorias historiográficas, senão teorias sobre a história.

\section{Atenção oblíqua na história da psicologia}

O terceiro ponto que gostaria de enfocar surge do reconhecimento da necessidade de um diálogo permanente entre a historiografia da psicologia no Brasil e a historiografia especificamente brasileira. Não ignorar a produção historiográfica brasileira significa algo mais do que apropriar-se de estudos realizados pelas novas escolas historiográficas nos últimos anos. É fundamental reconhecer a historiografia da psicologia como uma produção historiográfica no sentido forte do termo, ou seja, entender a história da psicologia como um campo que contribui de forma singular para a história das práticas culturais no Brasil. Nesse sentido, a historiografia da psicologia deve participar dos debates historiográficos colocados pelos historiadores brasileiros (e brasilianistas), enfrentando as questões com seu olhar próprio.

O diálogo permanente com a historiografia brasileira fará com que a história da psicologia não ignore a problematização das periodizações impostas a uma historiografia de um país como o Brasil, desde as questões colocadas pela fragmentação iniciada pela assim chamada "nova história" até a substituição da

\footnotetext{
${ }^{31}$ HELLER, Agnes. Teoría de la historia, 1982.
} 
narrativa tradicional por uma história-problema, passando pelo debate "revisionista" colocado pelo estruturalismo. Após o fracasso de uma periodização por ciclos econômicos e a segmentação do político, econômico e cultural, o historiador José Murilo de Carvalho chama a atenção para os deslizamentos de ênfase das “circunstâncias do homem" para o "homem em circunstância".32

Essa explosão da história, ou sua fragmentação em migalhas, como diz Dosse $^{33}$, está relacionada ao descentramento da historiografia causado pela crise das grandes teorias de explicação da história. Para enfrentar estas questões é necessário sair do caminho seguro oferecido pela historiografia das ciências, cuja face está voltada para uma tradição não especificamente brasileira, buscando-se a psicologia onde aparentemente ela não está ou não esteve. Este percurso exige uma abertura no conceito de fonte para a história da psicologia, buscando-a não apenas em textos tradicionalmente legitimados. É necessário que o esforço de construção do objeto histórico quebre a soberania do documento como texto de ciência. Muda-se assim a ótica analítica, localizando fontes que podem estar na grande imprensa ou mesmo nas transmissões de rádio, por exemplo, e não apenas originadas - ou mesmo geradas - em instituições de ciência.

Abrem-se assim brechas para uma história da psicologia redefinida como uma história da construção da significação, enfatizando a tensão que atravessa as comunidades de interpretação. Nesse caso, a história da psicologia poderia conectar-se com a história das práticas de recepção, como produções de sentido operadas a partir de determinações múltiplas (sociais, culturais, religiosas). Essa

\footnotetext{
${ }^{32}$ CARVALHO, José Murilo de. Pontos e bordados. Escritos de história e politica, 1998.

${ }^{33}$ DOSSE, F. A história em migalhas: dos Annalles à Nova História, 1992.
} 
história da psicologia deve colocar em lugar central a questão das práticas a partir das divisões do mundo social. Por fim, ela aponta não para a autonomização do político, mas sim para a compreensão de que toda transformação nas formas de organização e de exercício de poder supõe um equilíbrio de tensões específicas entre grupos sociais.

Não se trata apenas de enfatizar de forma redutora o uso que é feito de determinadas idéias e sua circulação, ou seja, suas condições de produção e recepção. Nesse sentido, algumas oposições são repensadas, como aquela entre criação e consumo, entre produção e recepção, entre alta cultura e cultura popular, entre ciência e não-ciência. Conforme Chartier $^{34}$, esta perspectiva oferece um contrapeso frente aquela que põe acento sobre os dispositivos discursivos ou institucionais que em uma sociedade tendem a disciplinar os corpos e as práticas. Longe de possuir a absoluta eficácia, estes dispositivos deixam necessariamente um lugar para o distanciamento, para o desvio, para a reinterpretação: a chamada atenção oblíqua. Cabe ao historiador buscar a gramática oculta ou imersa das práticas visíveis ou discursos. Entendendo cultura como um conjunto de significações que se enunciam em discursos ou práticas, a psicologia ganha um lugar privilegiado na história.

Essa perspectiva não pode perder de vista o laço que une a infra e a superestrutura, como parte da história do imaginário, considerada segundo fôlego da história das mentalidades. A história preserva assim sua ambição de globalidade, ao recusar a explosão de seu campo de análise. Se operamos no eixo da história da ciência, o tema fundamental passa a ser a autonomização da psicologia como

\footnotetext{
${ }^{34}$ CHARTIER, R. História cultural: entre práctica e representación, 1995.
} 
disciplina. Se, por outro lado, operamos no eixo da história da cultura, é possível traçar as rotas das metáforas na história da psicologia.

Apesar de aparecer como um campo acessório, a história da psicologia constitui-se como campo autônomo de investigação, e deve definir suas fronteiras em relação a outros campos. Contudo, essa definição deve-se dar a partir de pressupostos que, no caso da história da psicologia no Brasil, envolvem a explicitação tanto de uma concepção de história quanto de psicologia. A exploração da historicidade envolve a procura pelo formato radical de temas e questões. Negar a radicalidade da crítica histórica é ignorar a existência simultânea de elementos estabilizadores e perturbadores, unificar aquilo que é distinto, reduzir e homogeneizar a constelação de possibilidades em uma história da psicologia com rumo certo. A historiografia da psicologia no Brasil não é só um caso da historiografia da psicologia moderna, e não apenas por não termos atravessado a Idade Média. Por exemplo, o pensamento social latino-americano levantará a questão da nacionalidade em termos de raça, mas é claro que as sucessivas significações estão longe de ser homogêneas, e implicam todos os tons do darwinismo social e do recebimento local do spencerismo e do haeckelianismo, conforme ressaltamos nesta pesquisa.

No caso brasileiro, Roberto Schwarz ressalta o incômodo clima de pseudooriginalidade, este sim uma originalidade substancial ${ }^{35}$ instituída em um país onde grassava o "progressismo alvar". Esse incômodo clima de pseudo-originalidade não pode ser ignorado pelos historiadores da psicologia na periferia do capitalismo.

\footnotetext{
${ }^{35}$ SCHWARZ, Roberto. Um mestre na periferia do capitalismo. Machado de Assis, 1991, p.149.
} 


\title{
4 Da demência à infância anormal: emergência histórica da infância patologizada
}

\author{
A menos perigosa das loucuras
}

Ao apresentar as quatro classes de doenças do espírito - frenesi, mania, melancolia e imbecilidade - segundo Doublet (1721), Foucault faz uma rara referência às crianças: "A imbecilidade, aparentemente o grau menos asssustador e menos perigoso da loucura é, quando melhor considerado, o mais deplorável dos estados de espírito, pois é o mais difícil de curar. Os imbecis não são nem agitados nem furiosos; raramente sombrios, mostram um rosto estupidamente alegre e que permanece mais ou menos o mesmo, quer sintam prazer ou dor. A imbecilidade é consequência do frenesi, da mania ou da melancolia prolongada por muito tempo. $\mathrm{O}$ ressecamento do cérebro produz a imbecilidade nos velhos; o amolecimento ou a infiltração dessa víscera faz com que surja nas crianças". ${ }^{36}$ Esta concepção da criança como organismo deficiente está também presente nos primeiros trabalhos teóricos da medicina, em que o modelo de entendimento da criança é a patologia do adulto. Para o médico escocês Brown (1735-1877), a criança é naturalmente fraca

\footnotetext{
${ }^{36}$ FOUCAULT, M. História da loucura na Idade Clássica, 1978, p.538.
} 
ou debilitada, e todas as doenças infantis daí decorrem. A marca da instabilidade na infância é assim descrita por Cabanis (1757-1808) em seu Rapports du Psysique et du Moral d l'homme et lettre sur les causes premières: "Assim, a predominância relativa do sistema nervoso, a quantidade mais considerável de vasos, a elaboração ainda imperfeita de muco animal, acrescentada à superabundância de humidade que ele contem, a irritabilidade mais viva dos músculos; enfim, as alterações que possam acontecer, seja gradualmente seja por efeito de certas revoluções súbitas no sistema absorvente e linfático: essas são as considerações gerais que apresentam o estado dos órgãos nas crianças". 37

Até Rousseau, a ausência de fala era interpretada como um signo inequívoco da natureza corrompida na infância, pois é nesse não-falar que reside a proximidade com o animal. Mas o pequeno ser aprende a falar e aí reside a possibilidade de escolha entre o bem e o mal, que em Agostinho indicava uma disponibilidade infinita e latente para o mal. ${ }^{38} \mathrm{~A}$ infância é uma espécie de mal necessário, uma condição próxima do estado animalesco e primitivo. Como seres privados de razão, as crianças devem ser monitoradas nas suas tendências selvagens, o que pressupõe o controle das paixões. Já que existe esse período infeliz que é a infância, é preciso que nos livremos rapidamente dele, criando condições propícias ao crescimento da luz natural da razão cartesiana. Desprovida de logos -

${ }^{37}$ CABANIS, P.J.G. Rapports du Psysique et du Moral d l'homme et lettre sur les causes premières. $18^{\mathrm{a}}$ ed., 1844. Capítulo intitulado "De l'influence des âges sur les idées e les affections morales". p. 195. No original: "Ainsi, la prédominance relative du systeme nerveux; la quantité plus considerable de vaisseaux; l'éboration encore imparfait du mucus animal, jointe à la surabondance d'humidité qu'il contient; l'irritabilité plus vive des muscles; enfin, les changements qui surviennent, soit graduellement, soit par l'effect de certaines révolutions soudaines, dans le système absorbant et lymphathique: telles sont les considérations générales que présent l'état des organes chez les enfants".

38 A noção de infância para Agostinho segue o modelo de sua concepção de história. Em Agostinho, a redenção é o telos da história, mas não desemboca diretamente na história sem mediações. A redenção se insere na história através do plano divino universal, mas se contrapõe a ela depois do pecado original. Cf. ADORNO, T.W. Consignas. Ver artigo intitulado "Progresso". 
linguagem e razão - a infância o detém, porém em potência. Cabe à educação/formação realizar estas potencialidades e transformar esses pequenos seres em humanos dotados de linguagem, capazes de pensar e agir racionalmente. A infância é, ao mesmo tempo, o outro ameaçador da razão, mas também o terreno exclusivo de sua eclosão. Marca-se assim um estatuto paradoxal para a infância: território perigoso das paixões, zona escura do pecado e do erro, sem os caminhos que iluminam a razão, ela abriga, no entanto, a única chance de fazer surgir a razão que lhe é virtual. ${ }^{39}$

Os políticos e moralistas do século 17 orientaram a direção das almas no sentido de distinguir o homem do animal: “O que é um bebê? (...) senão uma besta rude na forma de homem? E o que é um jovem senão (por assim dizer) um burrico selvagem sem modos e sem freios?". A linguagem da infância "não era nem um pouco melhor que os sons produzidos pelos bichos mais sagazes quando se comunicam uns com os outros", 40 concluiu um autor do período de Jaime I, que governou no início do século. Crianças e loucos faziam parte de um mesmo gênero que negava a razão reta ou natural, não fazendo uso da linguagem. Em Hobbes, que publicou o Leviatã em 1651, o meio por excelência de fixação da razão é a linguagem, o suporte sensível da operação racional. É fatal para as crianças que, apesar de natural, não se nasce com a razão hobbesiana: “As crianças portanto não

\footnotetext{
${ }^{39}$ GAGNEBIN, Jeanne Marie. Sete aulas sobre linguagem, memória e história, 1997. Em especial o capítulo intitulado "Infância e pensamento".

${ }^{40} \mathrm{KEITH}$, Thomas. O homem e o mundo natural. Mudanças de atitude em relação às plantas e aos animais 1500-1800, 1988, p.46. Na escala de bestialidade havia uma hierarquia: "os loucos, que pareciam possuídos por bichos selvagens; os vagabundos, que não seguiam nenhuma vocação [em inglês calling, termo essencial do protestantismo inglês], mas viviam, no dizer do puritano William Perkins, 'uma vida de bichos'. Imagem semelhante perpassa as acusações da época contra os vadios, que não se 'associavam em famílias, mas se juntavam como animais'. Os mendigos também eram como os brutos, pois gastavam todo o tempo procurando comida" (p.53).
} 
são dotadas de nenhuma razão até que atinjam o uso da linguagem, mas são denominadas seres racionais devido à aparente possibilidade de terem o uso da razão na sua devida altura". ${ }^{41}$

A privação de razão tem suas consequências na infância. Sem razão não há lugar para as virtudes, apesar de algumas delas serem naturais. As crianças nascem como os animais, mas com duas desvantagens: não há o instinto de sobrevivência comparável ao instinto "societário" das abelhas e das formigas, e tampouco são dotadas de algum germe de razão garantidor de uma saída do mundo das sensações: "A crianças, os imbecis e os loucos, que não têm o uso da razão, podem ser personificados por guardiães ou curadores, mas não podem ser autores (durante esse tempo) de qualquer ação praticada por eles, a não ser que (quando tiverem recobrado o uso da razão) venham a considerar razoável essa ação". ${ }^{42}$

A concepção "moderna" da infância tem um de seus marcos em Rousseau, que publicou o Emílio em $1762 .{ }^{43}$ A noção burguesa de progresso norteia também a nova concepção de infância: é inevitável que o progresso esteja no adulto, restando à criança caminhar nos trilhos da razão até esse lugar privilegiado do tempo. Mas é também inevitável que se assuma a infância como germe desse progresso, já que as crianças fazem parte do grande gênero chamado humanidade. ${ }^{44}$ Com Rousseau efetua-se um corte em relação às representações da infância, que pode ser explicado

\footnotetext{
${ }^{41}$ HOBBES, Thomas. Leviatã I. , 1979 (Os pensadores). Capítulo V, "Da razão e da ciência", p.30.

${ }^{42}$ HOBBES, Thomas, Leviatã I, capítulo XVI, "Das pessoas, autores e coisas personificadas", p.97.

${ }^{43} \mathrm{Em}$ L'enfant et la vie familiale sous l'Ancien Regime [ARIÈS, Philippe. História social da criança e da família, 1981], Ariès defende a idéia de que o sentimento da infância não existia na Idade Média, quando as crianças eram vistas como animais até a idade de sete anos. A tese sofreu severas críticas de medievalistas, que apontaram generalizações excessivas sobre o período. Sobre a recepção do trabalho de Ariès ver BURKE, Peter. A Escola dos Annales (1929-1989): a revolução francesa da historiografia, 1997 e também DOSSE, François. A história em migalhas. Dos Annales à nova história, 1994.

${ }^{44}$ Conforme ADORNO, T.W. Consignas, s/d. Em especial, ver artigo intitulado "Progresso".
} 
por uma inversão: desconfia-se da razão e confia-se ilimitadamente na natureza, que passa a ser, paradoxalmente, germe de progresso. A expressão homem natural vem acoplada com a de perfectibilidade, essa faculdade virtual anterior à razão, na qual Rousseau vê a condição de possibilidade de uma evolução, de uma história, de uma razão, que levaram o homem do estado presumido - o estado de natureza - ao da desigualdade social. Está na natureza do homem estar em potência de sua própria história. Não se evoca uma falta original, uma queda, uma maldição. A natureza, no Emílio, é o telos do educador. ${ }^{45}$ Rousseau revela assim dois mundos: o da infância, condição de possibilidade de uma pedagogia efetiva, e o do primitivo e do homem selvagem. A infância é algo que os humanos tem em comum com os animais, mas a diferença de homem para homem deverá ser maior ainda do que a existente de animal para animal, pois "sendo o animal e o homem tratados igualmente pela natureza, todas as comodidades que o homem a si oferece, mas não aos animais, são outras tantas causas particulares que fazem com que mais perceptivelmente degenere". ${ }^{46}$

\section{Afecções morais}

Essa concepção de infância como germe de progresso permite que, ao final do século VXIII, ocorra a primeira distinção entre imbecilidade e demência. Até então, demência e imbecilidade eram tratadas como sinônimos, como se a

\footnotetext{
${ }^{45}$ Conforme SALOMON-BAYET, Claire. "Jean-Jacques Rousseau". In: CHÂTELET, François (org.). História da filosofia. O Iluminismo. O século XVIII, 1982.

${ }^{46}$ ROUSSEAU, Jean Jacques. Discurso sobre a origem e os fundamentos da desigualdade entre os homens, 1983, p.242.
} 
imbecilidade fosse uma mistura de loucura e enfermidade sensorial. Nos dois casos tratava-se de uma afecção que envolvia ao mesmo tempo a memória, a imaginação e o juízo. No entanto, a distinção entre as idades aos poucos se estabelece, sendo que no primeiro momento tem apenas um valor cronológico, uma vez que nem os sintomas nem a natureza da doença variavam segundo a idade na qual começava a se manifestar. O que existe na alma ou na atividade do espírito é paralisado pelo efeito da imbecilidade, enquanto na demência o que é perturbado é o funcionamento da razão. ${ }^{47}$ Um segundo deslocamento fará com que imbecilidade e demência se distinguam não mais tanto pela precocidade da oposição entre elas, nem mesmo pela faculdade atingida, como pelas qualidades que lhes pertencem e que comandarão em segredo o conjunto de suas manifestações. Para Pinel (1745-1826), a diferença entre imbecilidade e demência é, em suma, a que existe entre imobilidade e movimento. No idiota, há uma paralisia, uma sonolência de 'todas as funções do entendimento e das afecções morais'. Na demência, pelo contrário, as funções essenciais do espírito pensam, mas pensam no vazio, é como um movimento puro do espírito, sem consistência nem insistência, uma fuga eterna que o tempo não consegue reter na memória. É preciso salientar ainda que, para Pinel, as causas dos diferentes tipos de loucura não eram nada específicas salvo no idiotismo congênito, mas este era apenas uma parte do idiotismo. ${ }^{48}$

\footnotetext{
${ }^{47}$ No Journal de Médicin de agosto de 1785, são descritos os medicamentos recomendados para tratamento da imbecilidade; "Quando esse estado é consequência ou o último período de uma outra doença, oferece pouca esperança. A primeira coisa a fazer é restaurá-los com boa alimentação; depois se fará com que tomem águas termais; serão purgados com raiz de briônia e uma infusão com aguardente; podem tentar também os banhos frios e as duchas". Cf. Notas em FOUCAULT, História da loucura na Idade Clássica, p. 540.

${ }^{48}$ Cf. BERCHERIE, P. Os fundamentos da clínica. História e estrutura do saber psiquiátrico, 1989, p.39.
} 
Até os primeiros três quartos do século XIX esta 'deficiência mental' pode ser apontada como única doença psíquica nomeada na criança. É um período consagrado à discussão da noção de deficiência mental tal como Esquirol (17721840) a definiu sob o nome de idiotia, em 1820, recorte que não é fruto de uma observação da criança, mas que deriva de um momento capital da história da psiquiatria do adulto. O que importa salientar é que pela primeira vez faz-se uma divisão daquilo que se chamava unitariamente de loucura. Assim, uma divisão se introduz entre a loucura propriamente dita, a loucura que aparece no adulto, e uma doença congênita, que pode ser reconhecida na infância, e pode-se observar mais tarde no adolescente e no adulto. ${ }^{49}$

Paralelamente, no campo teórico-experimental da clínica, Billard (18001832) passa a empregar a correlação anátomo-clínica na investigação da patologia da criança, reduzindo a percepção da criança como algo apreensível apenas por sua debilidade e suscetibilidade. Billard publica seus estudos anátomo-clínicos em 1828 e estabelece a normalidade orgânico-funcional da criança em correlação com a faixa etária, deslocando a análise do referencial adulto. Já não se trata de ver na criança um ser cujo corpo é muito quente ou cujas fibras são muito frouxas; nas diferentes idades passa a ser apontado um comportamento infantil normal.

Para este período, a loucura na criança é a idiotia, que se junta às perturbações causadas pela epilepsia, já bem estudada na época. Acreditava-se que as doenças que atingiam as crianças constituíam um freio ao desenvolvimento de todas as faculdades intelectuais. Quanto ao grau de irreversibilidade deste quadro, dois conceitos se opunham: o primeiro, oficial, de Pinel e Esquirol, para quem o

\footnotetext{
${ }^{49}$ BERCHERIE, P. La clinique psychiatrique de l'enfant: étude historique. Ornicar?, 1983.
} 
déficit global era definitivo e o prognóstico totalmente negativo. O segundo conceito está ligado em particular aos educadores Séguin e Delasieuve. Para eles, o déficit comprometeria o conjunto do desenvolvimento se a educação se limitasse às modalidades tradicionais. Haveria, portanto, a necessidade de se recorrer a métodos especiais. O ponto de partida dessas teorizações são as experiências de Itard com o menino que ele chamou de Vitor, conhecido como o Sauvage de l'Aveyron. ${ }^{50}$ Capturado em 1797, o menino foi levado para Paris e examinado por Pinel, que o considerou um idiota incurável. Depois foi confiado a Itard, que acreditou que se tratava de uma criança normal, mas privada do contato social e em particular da linguagem, por seu isolamento na floresta. ${ }^{51}$

Tocar mais a alma que o corpo

A primeira infância e a adolescência passam a ser considerados momentos críticos. A adolescência foi retomada ao longo do século XIX, e colou-se a uma patologia própria, a hebefrenia, definida como uma 'necessidade de agir que acarreta um desprezo por todos os obstáculos e todos os perigos', levando ao

\footnotetext{
${ }^{50}$ Sobre Itard, ver o filme de François Truffaut, L 'enfant sauvage (1970), em que o próprio diretor atua no papel do educador. Ver também a análise da Mémoire sur les premiers développements de Victor de l'Aveyron (1801) realizada em PESSOTTI, Isaías. Deficiência mental: da superstição à ciência, 1984.

${ }^{51}$ Segundo Bercherie, o menino apresentava múltiplos traços de uma criança autista, mas a noção global de idiotia cobria esse tipo até os anos 1930. Apesar de não ter tido sucesso com Vitor, Itard obteve incríveis resultados com seus métodos, extrapolados para a educação de crianças surdas-mudas. Essa tradição de educadores fundará uma escola fecunda que originará a educação especial na França por Delasieuve, Bourneville e seus discípulos, que fundam nos Estados Unidos o sistema de instituições especializadas para crianças "anormais", e que através de Maria Montessori inspirará o que chamou-se de "nova pedagogia".
} 
assassinato. ${ }^{52}$ Além de ser um perigo para o indivíduo, a adolescência era também um perigo para a sociedade, deslizando-se para o tema do delinquente. A primeira infância também era alvo de práticas especiais, entre elas a puericultura, que traçou uma linha divisória nítida entre o que pertencia à medicina legítima e o que dela deveria ser excluído. ${ }^{53} \mathrm{Na}$ nova constelação familiar em que a criança passa a carregar um perigo social, o filho não pertence aos pais: ele é o futuro da nação, produtor, reprodutor, cidadão e soldado do amanhã: "entre ele e a família, principalmente quando esta é pobre e tida como incapaz, insinuam-se terceiros: filantropos, médicos, estadistas que pretendem protegê-lo, educá-lo, discipliná-lo. As primeiras leis sociais foram promulgadas tendo como objeto as crianças (...) isto significa que a infância é uma daquelas zonas limítrofes onde o público e o privado se tocam e se defrontam, muitas vezes de maneira violenta. Objeto de disputa de poderes, a infância também é lugar de saber, que se desenvolvem sobretudo no último terço do século 19, com o esforço conjunto da medicina, da psicologia e do direito". 54

Segundo Michelle Perrot, à medida que se aproxima o final do século XIX, é por meio da família que, antes da existência da escola obrigatória, as crianças têm acesso à instrução, principalmente à leitura: "o método Jacotot é um método de 'pais de família' - e também de mães, muito mais alfabetizadas do que se imagina, além de se tornarem depositárias (...) da sabedoria do corpo e dos saberes clínicos. Assim, a família popular não resulta de uma imposição da ordem burguesa, mas é

\footnotetext{
${ }^{52}$ PERROT, Michelle. "Figuras e papéis". In: Michelle Perrot et all (org.) História da vida privada v. 4. Da revolução francesa à primeira guerra, 1991, p.163.

${ }_{53}^{53}$ Sobre a puericultura ver BOLTANSKI, L. Primme éducation et morale de classe, 1984.

${ }^{54}$ PERROT, Michelle. "Figuras e papéis". In: Michelle Perrot et all (org.) História da vida privada v. 4. Da revolução francesa à primeira guerra, p.148.
} 
um lugar natural de apropriação do saber e de emancipação do pobre". ${ }^{55}$ Existem ainda outras missões atribuídas à família, “com uma pressão crescente à medida que se aproxima o final de um século assombrado pelos fantasmas da redução da natalidade e do medo da degenerescência: a reprodução de uma raça numerosa, fecunda e saudável, uma sexualidade praticada sem fraudes nem esmorecimentos", continua Perrot. Os médicos sacralizavam o casamento ao mesmo tempo como regulador das energias e forma de evitar as perigosas relações dos bordéis, “destruidores da raça". Isto porque, principalmente na segunda metade do século XIX, as 'mitologias da hereditariedade', desenvolvidas tanto pelos médicos quanto pelos romancistas, o temor dos grandes flagelos sociais - a tuberculose, o alcoolismo, a sífilis - , o terror às 'taras' transmitidas e ao sangue 'estragado' erigem a família num elo cuja fragilidade requer uma vigilância constante. Conforme Perrot, mesmo os anarquistas neomalthusianos deixam-se cair de roldão nas seduções da eugenia, esse sonho de purificação da progênie derivado das ambiguidades do darwinismo social.

Em sua análise, a historiadora evidencia o modo burguês de educar, que procura agora tocar mais alma que o corpo: "Nos meios burgueses, mais do que nos aristocráticos, as crianças já não apanham muito em casa. Aqui e ali subsistem algumas varas e açoites de corda, mas cada vez mais reprovados. Perduram na escola e em certos liceus que pretendem impor uma disciplina militar (...) Os internatos, em sua publicidade, chegam a especificar nos prospectos que excluem tais métodos. (...) Trata-se agora de tocar mais a alma do que o corpo (...) Aumenta

${ }^{55}$ PERROT, Michelle. "Funções da família". In: Michelle Perrot et all (org.) História da vida privada v. 4. Da revolução francesa à primeira guerra, 1991, pp.104-119. 
a distância entre os estabelecimentos públicos e religiosos, estes mais arcaicos em suas concepções pedagógicas, quer se trate de higiene ou da punição. Quanto à palmatória, os frades e os religiosos serão os últimos a abrir mão dela, pelo menos em relação às crianças das classes populares, como mostram inúmeras biografias". ${ }^{56}$ Por outro lado, no campo e entre as classes populares urbanas e pequeno burguesas, "sovas e vergastadas são plenamente admitidas, desde que não ultrapassem certos limites; ou uso do bastão ou do açoite de corda, geralmente empregado de mãos nuas, fica reservado aos mestres de aprendizagem ou de instituições, como uma marca de exterioridade física. Apanhar faz parte das lembranças da infância operária no século 19 (...) Nas oficinas e nas fábricas, é comum que o aprendiz rebelde ou desajeitado receba uma 'taréia' dos operários adultos encarregados de ensinar o ofício. No fundo de tudo isso encontra-se uma série de representações: a de uma força rebelde a ser domada, a dureza da vida que deve ser aprendida". ${ }^{57}$

"Através de várias observações a que está sujeita, inclusive pelo detalhismo dos boletins escolares, a criança vai assumindo rosto e voz. Sua linguagem, seus afetos, sua sexualidade, suas brincadeiras são objeto de anotações que dissipam os estereótipos, em favor de casos concretos e desconcertantes. A infância, a partir de então, é vista como um momento privilegiado da vida. Toda autobiografia começa e se demora nela, enquanto o chamado romance 'de formação'descreve a infância e a juventude do herói. Para tudo e contra tudo, a

\footnotetext{
${ }^{56}$ PERROT, Michelle. "Figuras e papéis". In: Michelle Perrot et all (org.) História da vida privada v. 4. Da revolução francesa à primeira guerra, 1991, p.158.

${ }^{57}$ PERROT, Michelle. "Figuras e papéis". In: Michelle Perrot et all (org.) História da vida privada v. 4. Da revolução francesa à primeira guerra, 1991, p.159.
} 
infância se torna a idade fundadora da vida, e a criança vira uma pessoa", ${ }^{58}$ conclui Perrot.

\section{Infância em perigo e infância perigosa}

É nesta configuração que a filantropia articula-se com o Estado e a sociedade em dois pólos complementares: um pólo assistencial que remete para a esfera privada as demandas originalmente formuladas ao estado em termos de direitos ao trabalho e à assistência; e um pólo médico-higienista, que não tem como objetivo exatamente impedir a expansão do estado liberal mas sim dar suporte às decisões de onde intervir para evitar o risco da degradação da sociedade por processos de enfraquecimento físico e moral. O pólo medico-higienista expressa-se pela preocupação com a educação, saúde e criação das crianças, com as condutas e hábitos saudáveis para a família e os indivíduos, através de uma pregação moral que busca redefinir o papel da família e seus componentes para melhor cumprirem sua função social. Esse processo também continua no sentido do direito privado, criando-se todo um arcabouço de tutela sobre o comportamento da família, e principalmente sobre sua responsabilidade na conservação das crianças. É nesse sentido que o ensino básico passa a ser obrigatório e surgem os mecanismos de punição à família pelos maus tratos à criança $\mathrm{e}$ - fundamentalmente - aqueles de aplicação à infância criminalizada.

Coloca-se assim mais claramente a fronteira entre as infâncias, na sua dupla forma: a infância em perigo, aquela que não se beneficiou de todos os cuidados da

\footnotetext{
${ }^{58}$ PERROT, Michelle. "Figuras e papéis". In: Michelle Perrot et all (org.) História da vida privada v. 4. Da revolução francesa à primeira guerra, 1991, p.162.
} 
criação e da educação almejados; e a infância perigosa, a da delinquência. Para esses casos, a boa consciência da caridade é substituída pela busca de técnicas eficazes. Para as crianças das famílias burguesas, busca-se uma liberação protegida, através de normas de higiene e das atividades escolares, incentivadas por médicos e pedagogos em colaboração dedicada com as mães. Para a criança pobre, a mãe deve empreender uma vigilância das liberdades.

Uma nova configuração em torno do objeto infância materializa-se assim na publicação da primeira coleção de tratados sobre psiquiatria da criança em língua francesa, alemã e inglesa, a partir de 1880. Caracteriza-se pela constituição de uma prática decalcada da clínica e da nosologia elaborada para o adulto, segundo a mudança impressa pela clínica de Falret e seu discípulo, Morel, que publicou em 1857 Traité des dégénerescences physiques, intellectuelles et moralles de l'espèce humaine. Morel elaborou a origem do termo e da noção de desequilíbrio e o conceito mais moderno de desarmonia evolutiva foi aí definido, a partir de uma extensão da noção de deficiência aplicada a algumas partes, e não à globalidade do psiquismo, como antes em Séguin e Delasieuve. Os conceitos trabalhados por Morel vão orientar a atenção na direção da infância "anormal" e também na direção da existência, já na criança, de uma patologia mental, ao identificar um conjunto de estigmas de degeneração. É dessa época também o aparecimento de uma rubrica etiológica particular, aquela que se chamou de l'épuisement, a qual se liga o fracasso escolar e o onanismo, temas de inúmeros estudos sobre a patologia mental do adolescente. Em todo caso, a psiquiatria infantil, fora a deficiência mental, vai permanecer mais como um objeto de curiosidade e de um campo complementar à 
clínica e às teorias psiquiátricas do adulto, que um campo autônomo de investigação. ${ }^{59}$

${ }^{59}$ É apenas na virada do século, com a importação de conceitos da nosologia de Kraepelin, que a psiquiatria infantil constituiu-se num campo de investigação clínica. A segunda geração dos tratados de psiquiatria infantil, que apareceu entre os anos 1910-1925, é resultado desse processo: Strohmayer (1910) e Homburger (1926) em alemão, Sante de Sanctis (1925) em italiano. A língua francesa não está representada nessa época, ao contrário do campo da deficiência mental, em que os trabalhos são numerosos em torno de Bourneville e do teste de Binet e Simon. Essas novas rubricas etiológicas de deficiência vão progressivamente destacar-se de uma entidade particular que coloca um importante problema conceitual: o que Sante de Sanctis denominou em 1906 a 'demência precocíssima', em que, segundo os autores, a criança caminhava rápido para um estado de idiotia, apesar de persistir uma certa capacidade de atenção e focalização, e sobretudo a conservação de uma fisionomia inteligente que diferia notadamente de outros quadros. A partir da publicação em 1911 da obra fundamental de Bleuler sobre a esquizofrenia, a idéia da existência de uma psicose autística na criança, distinta da deficiência mental, começa a se impor. O momento também é marcado pelo crescimento das idéias psicanalíticas sobre a clínica infantil, apesar da integração das noções trazidas pela psicanálise não operar de maneira unitária. É essencialmente na língua inglesa que uma concepção de conjunto vai se apontar e tornar a clínica psiquiátrica da infância relativamente homogênea: o tratado de Kanner, cuja primeira edição é de 1935 e que permanece como obra fundamental de referência nesse campo. 


\section{Parte II}

\section{Categorias psicológicas na construção histórica da infância criminalizada}

\section{Crianças que trabalham e crianças histéricas}

Até fins da década de 1980, a historiografia brasileira pouco se ocupou da criança e mesmo da família. Conforme a historiadora Maria Luiza Marcilio, "foi a utilização de recursos da demografia histórica no Brasil e da chamada História Nova, ambas valorizando as pesquisas sobre excluídos sociais, que possibilitou a descoberta de realidades novas, inusitadas na nossa paisagem social histórica". ${ }^{60}$ Desde então, surgiram algumas publicações originadas em pesquisas (dissertações e teses), em geral coletâneas que abrangem a infância desde a Colônia até textos sobre a atual configuração da assistência pública à infância. ${ }^{61}$

\footnotetext{
${ }^{60}$ MARCILIO, Maria Luiza. História social da criança abandonada, 1998.

${ }^{61}$ Refiro-me aqui a PRIORI, Mary del (org.). História da criança no Brasil, $1{ }^{\mathrm{a}}$ ed. em 1991 e $3^{\mathrm{a}}$ ed. em 1995; FREITAS, Marcos Cesar de (org.). História social da infância no Brasil, 1997; PRIORI, Mary del (org.) História das crianças no Brasil, 1999.
} 
Via de regra, as publicações sobre história da infância no Brasil tratam da criança pobre. Venda de escravos, abandono de bebês, a trágica estatística da mortalidade ao longo dos séculos de funcionamento das rodas dos expostos, crianças operárias. As pesquisas indicam que logo após a abolição do tráfico de escravos, em 1850, surgiu uma preocupação com políticas públicas cujo alvo era a grande classe das crianças pobres consideradas "em perigo". Foram criados então vários Asilos de Educandos em quase todas as capitais regionais. Segundo Marcilio, a ideologia que fundamentou essas novas instituições incluía a instrução elementar, a formação cívica e a capacitação profissional das "crianças desvalidas".

A década de 1870 assinala o início de um novo momento, marcado pela promulgação da Lei do Ventre Livre somada à força social que emergia - o poder médico-higienista: "Essa lei renovou o pavor nas classes privilegiadas de se verem, de repente, sem trabalhadores domésticos. Esse temor levou-as a repensar as políticas e as formas de proteção à infância desvalida e aos ingênuos (filhos livres de mães escravas, depois de 1871), preparando-os para o serviço doméstico". ${ }^{62}$

Como regra geral, as etapas etárias eram as mesmas para a população livre e para a população escrava. Havia porém uma diferença fundamental ligada à função social desempenhada pelas categorias de idade: "a criança branca livre e até mesmo a criança de cor livre podem ter seu prazo de ingresso na vida ativa protelado, enquanto a criança escrava, que tenha atingido certa idade, entra compulsoriamente no mundo do trabalho. Há pois um certo momento em que o filho da escrava deixa

${ }^{62}$ MARCILIO, Maria Luiza. História social da criança abandonada, 1998, p.206. 
de ser a criança negra ou mestiça irresponsável para tornar-se uma força de trabalho para os seus donos". ${ }^{63}$

Esta cisão na população infantil levaria à criação, na cidade do Rio de Janeiro, mesmo antes da promulgação da Lei do Ventre Livre, do Instituto de Menores Artesãos da Casa de Correção da Corte. Conforme o Regulamento da instituição, as crianças lá recolhidas eram divididas em duas seções: uma hospedava aqueles presos pela polícia por serem considerados vadios, vagabundos ou abandonados e aqueles que, "por má índole não possam ser corrigidos por seus pais ou tutores". Na segunda seção ficariam aqueles que "por sua orfandade não puderem receber uma educação conveniente e apropriada em outro lugar". ${ }^{64}$

Os estabelecimentos têxteis e as pequenas oficinas da cidade de São Paulo já na década de 1870 são locais de trabalho para crianças e adolescentes, o que pode ser deduzido pelos anúncios publicados na imprensa solicitando mão-de-obra. ${ }^{65}$ Desde então a presença das crianças no mercado de trabalho se amplia, principalmente nos estabelecimentos industriais. ${ }^{66}$ Paralelamente ao aumento da presença de crianças e adolescentes no mercado de trabalho da indústria que se anuncia, "começava-se a se pensar na fundação de grandes estabelecimentos totais

${ }^{63}$ MATTOSO, Kátia de Queirós. "O filho da escrava". In: PRIORI, Mary del (org.) História da criança no Brasil, 1995, p.78.

${ }^{64}$ Coleção de Leis do Império. 1861. Actos do Poder Ececutivo, p.117. Apud MARCILIO, Maria Luiza. História social da criança abandonada, 1998, p.209.

${ }^{65}$ Conforme MOURA, Esmeralda Blanco B. "Infância operária e acidente de trabalho em São Paulo". In: PRIORI, Mary del (org.) História da criança no Brasil, 1995, p.113.

${ }^{66}$ Esse aumento da participação das crianças no mercado de trabalho veio acompanhado de discussões sobre a questão na segurança no trabalho por parte daqueles em defesa dos interesses do trabalhador: "A partir do final do século passado, o trabalho do menor e o acidente de trabalho constituem isoladamente pontos cruciais da questão social em São Paulo, que, quando associados, adquirem conotação ainda mais ampla e mais profunda". Cf. MOURA, Esmeralda Blanco B. "Infância operária e acidente de trabalho em São Paulo". In: Priore, Mary del (org.) História da criança no Brasil,1995, p.115. 
de internamento e de segregação da sociedade para crianças e adolescentes carentes e sem família. Estes estabelecimentos passaram a se multiplicar particularmente depois da Abolição da Escravidão e da instalação da República. O Código Penal de 1890 incluía em seus artigos a premência de se criar, ainda, instituições preventivocorrecionais, de grande porte" informadas pela ciência, conforme veremos em detalhe mais adiante. ${ }^{67}$

Essa "filantropia científica" visava preparar a criança pobre para o mundo do trabalho, e sua política de abertura de novos estabelecimentos acelerou-se nas últimas décadas do século XIX e nas primeiras do século XX. O momento marca também a transição operada na inserção social dos juristas, que deixam seu campo de atuação tradicional e entram decididamente no setor da infância desvalida e delinquente: "Medicina e direito reelaboraram, então, suas propostas de política assistencial, enfatizando a urgência na reformulação de práticas e de comportamentos tradicionais e arcaicos, com o uso de técnicas científicas" ${ }^{68}$

\section{Abandonada-viciosa-delinquente}

Segundo o Relatório do Secretário de Negócios da Justiça relativo ao ano de 1891, no anexo relativo à Força Pública, "tornava-se inadiável a organização do regime penitenciário, de acordo com o sistema do novo Código Penal e concomitantemente a instituição de asilos para colocação dos menores, vagabundos

\footnotetext{
${ }^{67}$ Cf. MOURA, Esmeralda Blanco B. "Infância operária e acidente de trabalho em São Paulo". In: PRIORI, Mary del (org.) História da criança no Brasil, 1995, p.207.

${ }^{68}$ MARCILIO, Maria Luiza. História social da criança abandonada, 1998, p.194.
} 
e viciados, mais como meio de prevenir a possibilidade dos delitos desses menores do que de reprimir os crimes por eles cometidos". ${ }^{69}$ Segundo o chefe de polícia, no mesmo relatório, muitas providências precisavam ainda ser tomadas para a manutenção da ordem, repressão aos crimes, contra a vadiagem e a mendicidade, sem contudo haver referência nas estatísticas quanto aos "menores" - objeto-deprevenção.

No Relatório do ano seguinte, avalia-se a penitenciária como "oposta aos rudimentais princípios da ciência criminal". Sendo assim, no que se referia às crianças, o Relatório reafirma que desde 1878 "reclamava o ilustre magistrado paulista Toledo Piza, hoje um dos ornamentos do Supremo Tribunal Federal, sobre a falta de instituições adequadas ao emprego do tempo e do ensino profissional dos órfãos e dos menores abandonados. Insistiram depois nessa falta quase todas as autoridades que o sucederam no cargo de chefe de polícia e no entanto até o presente ainda não se conseguiu o importante melhoramento. Prevenindo a tempo, pode a administração livrá-la de infortúnios prováveis e igualmente combater, pelo trabalho e pelo regime da vida escolar, tendências viciosas, frequentemente manifestadas e talvez adquiridas, unicamente pelo desamparo e pela privação do poderoso corretivo da família. Ficará ela assim isolada do mal e já não será pequeno o serviço de concorrer para retirar da sociedade futuros elementos de perturbação e de desordem (...) A idéia de fundação de uma casa, onde se ensinassem as artes mecânicas, julgamos preferível a de uma colônia ou colégio agrícola, pois além de encontrar numerosos pretendentes, não oferece ainda a carreira das artes manuais

\footnotetext{
${ }^{69}$ Relatório do Secretário de Negócios da Justiça relativo ao ano de 1891, Anexo relativo à Força Pública, p.7.
} 
compensações suficientes num país como o nosso, tão pouco afeiçoado à vida industrial e principalmente em São Paulo, onde bem ao contrário, os serviços da lavoura, graças aos admiráveis recursos de todas as zonas e ao êxito total do menor dispendo empregado, com razão merecem a primazia das atividades e dos capitais disponíveis". ${ }^{70} \mathrm{O}$ Chefe de Polícia antecipava assim decisões tomadas no $\mathrm{V}$ Congresso Internacional sobre Prisões, realizado em Paris três anos depois, quando foi proposto que crianças menores de 12 anos deveriam ser enviadas para instituições de "preservação" onde o treinamento deveria ser particularmente encaminhado para trabalhos agrícolas. ${ }^{71}$

Ao final do século XIX, portanto, setores do poder público paulista indicavam para esse grupo de crianças o trabalho no campo, para o qual faltavam braços. Essas crianças deveriam receber apenas a "educação intelectual que se cifra em ler, escrever e contar, a fim de não se sacrificar o objetivo primordial, que é despertar-lhes o gosto pelos trabalhos rurais e deixá-los aptos a execução de qualquer deles". ${ }^{72}$ Assim ficaria "inteiramente satisfeita a legítima aspiração de socorrer os menores e os órfãos aludidos e de moralizar os que, baldos dos cuidados de toda assistência, se houvessem por ventura desviado da boa conduta". ${ }^{73}$

Segundo o Relatório do Chefe de Polícia em 1892, os 3950 criminosos retidos na capital eram classificados da seguinte forma: 1239 desordeiros, 573 gatunos, 386 vagabundos, 356 ébrios e 337 ébrios desordeiros. Segundo o chefe de polícia, "não era raro ver-se um vagabundo ou um menor, suscetíveis de

\footnotetext{
${ }^{70}$ Relatório do Secretário de Negócios da Justiça relativo ao ano de 1892, p.83.

${ }^{71}$ Conforme PLATT, Anthony M. The child savers, 1977, p.51.

${ }^{72}$ Relatório do Secretário de Negócios da Justiça relativo ao ano de 1892, p.83.

${ }^{73}$ Relatório do Secretário de Negócios da Justiça relativo ao ano de 1892, p.84.
} 
regeneração, lançados entre quatro paredes com um facínora", pois na cadeia da capital só existia um carcereiro e um ajudante. Deve-se salientar ainda que conforme o Relatório Oficial - na verificação de óbitos do serviço médico-legal da capital, de um total de 365 seriam 126 menores, sendo 58 meninos e 68 meninas.

As exigências da nova "ciência criminal" associada à sagacidade psicológica de seus praticantes surgiam assim formuladas dois anos depois, nas palavras do Promotor Público: "está provado que a descoberta de criminosos muito depende do estudo dos fatores antropológicos do crime. A tatuagem, a antropometria, a fisionomia, as condições físico-psíquicas, os dados sobre a sensibilidade, a atividade reflexa, as reações vaso-motoras, o campo visual dos criminosos tornando-se mais fácil e completa a série de provas da identidade pessoal e dos indícios de cometer tal ou tal crime, bastarão muitíssimas vezes para dar aos agentes de polícia e aos juízes de instrução uma direção científica em suas investigações que agora não dependem empiricamente senão de suas disposições pessoais de sagacidade psicológica". ${ }^{74}$

Segundo o promotor, o peso da educação seria apenas um vetor constitutivo do caráter, ao qual se juntaria com mais peso a hereditariedade. Seguindo a escola criminalista italiana, o poder público propunha assim a instalação de asilos penitenciários que, desde cedo, atuariam sobre as tendências viciosas precoces: "Conquanto ainda seja duvidoso que um instinto moral definitivo possa criar-se pela educação na primeira infância, contudo parece demonstrado que a educação não representa senão [grifado no original] uma das influências que atuam nos

\footnotetext{
${ }^{74}$ Relatório da Justiça relativo ao ano de 1894, p.32.
} 
primeiros anos de vida que, com a hereditariedade e a tradição contribuem para a gênese do caráter (...) Disto se conclui que todo nosso esforço deve consistir na criação de um asilo penitenciário, destinado unicamente aos menores, tipo do Elmira Reformatory". E continuava o policial de forma quase poética: "Procuremos inocular no espírito deles os sãos princípios da moral, não lhe recusemos mesmo o bálsamo consolador da religião, estimulemo-los com o trabalho, concedamo-lhes distrações, proporcionemo-lhes o desenvolvimento intelectual, e então veremos que os cárceres mais facilmente se fecharão, os crimes se tornarão mais raros, e moços cujos futuros era ameaçador, crianças cujo destino negro entrevia-se nas suas precoces tendências, tornaram-se bons cidadãos, obreiros do progresso e engrandecimento da pátria". ${ }^{75}$.

Elmira era considerado o reformatório modelo norte-americano, e por isso mesmo sofreu um processo de superlotação. Havia sido construído para 500 celas, mas em torno de 1899 recolhia 1500 crianças. Por outro lado, os reformatórios se espalharam rapidamente pelos Estados Unidos e cientistas europeus cruzavam o Oceano para admirar o trabalho de seus colegas pragmáticos. O programa disciplinar envolvia exercícios militares, "treinamento da vontade" e longas horas de trabalho tedioso. ${ }^{76}$

Tornava-se claro que, sob as condições às quais eram submetidas as crianças e adolescentes na cadeia seria impossível “inocular” princípios morais balizadores para o mundo do trabalho. Em visita à cadeia, o promotor público encontrou "numa prisão em que se achavam cento e tantos ébrios, vagabundos e desordeiros, doze

\footnotetext{
${ }^{75}$ Relatório do Secretário de Negócios da Justiça relativo ao ano de 1894, p.51.

${ }^{76}$ Conforme PLATT, Anthony M. The child savers, 1977, Capítulo 3.
} 
menores de 14 anos (...) A sodomia é um dos vícios característicos das prisões, e portanto não é necessário indagar o que se passou com os menores". ${ }^{77}$

Mendicidade e vagabundagem exigiam dos poderes públicos medidas urgentes entre a assistência e a punição, efetuando-se assim uma cisão entre aqueles já criminosos e os apenas viciados, ambos em um estágio seguinte e consequente dos "abandonados", para quem o trabalho seria a solução. Ainda conforme o Relatório, “a mendicidade começa a manifestar-se, ou como exploração indecorosa ou gerada pela invalidez, e não estão autorizadas as medidas repressivas que conviria empregar, sendo já oportuno possuir uma casa que medeie entre o abrigo e a detenção. Não falando da vagabundagem, cujo incremento igualmente merece que se trate de contê-la, o mesmo embaraço de colocação e de destino surge quanto aos menores, delinquentes ou ociosos, diante da ausência de asilos que sejam para os jovens criminosos institutos correcionais e, para a outra classe, a dos unicamente viciados, verdadeiros estabelecimentos de educação, evitando-lhes a permanência nas prisões comuns", ${ }^{78}$

Após três anos no cargo, o chefe de polícia concluiu que o Estado é impotente diante da situação da capital, e solicita a participação de setores filantrópicos já organizados no salvamento moral de crianças. Segundo ele, uma das "providências mais palpitantes (...) é a criação de um estabelecimento de trabalho e de instrução que se destine ao recolhimento do número infindo de abandonadas crianças, que diariamente vagam pelas ruas da capital. A aceitação dessa medida e de outras análogas consagradas pela experiência de quase três anos de exercício no

${ }_{77}$ Relatório do Secretário de Negócios da Justiça relativo ao ano de 1894, p.47.
78 Relatório do Secretário de Negócios da Justiça relativo ao ano de 1894, p.36. 
cargo [chefe de polícia] de que me investiu a confiança será um poderoso dique à consequente dissolução de costumes, de que são causas estas classes desprotegidas e, por isso, expostas à ociosidade e ao vício, fatores principais da abjeção moral. Uma simples inspeção pelas ruas principais da cidade confirmará a cena emocionante de maltrapilhas crianças a importunar transeuntes, mendigando (...). $\mathrm{Na}$ impossibilidade de criar o governo de pronto, um estabelecimento dessa ordem, vos lembro como medida de alto valor, serem aproveitados os estabelecimentos já existentes nessa Capital, um a cargo das Damas de Caridade e outro a cargo da Congregação Salesiana, ambos com seus edifícios próprios e perfeitamente montados, concedendo o governos os subsídios relativos ao número de crianças que lhes forem confiadas". 79

Tudo indicava que as intenções e princípios de uma nova ciência criminal não tardariam a chegar ao governo paulista. Logo foi instalado o 'Serviço de Identificação de criminosos pelo sistema antropométrico', instalado naquele ano de 1894. A polícia já dispunha de ‘seção fotográfica’ organizada, faltando somente os instrumentos da seção antropométrica: um compasso de volta, um compasso cursor grande e outro pequeno, duas tiras de encerado graduado para a estatura e envergadura e dois bancos de madeira. Tantos avanços científicos contrastavam com dados do próprio Relatório: naquele ano de 1894, dos 283 presos na cadeia da capital, pelo menos 139 eram considerados analfabetos.

Para o bem-viver nas ruas de São Paulo foi criada no ano seguinte a Guarda Cívica, "um corpo dotado da precisa habilidade e incumbido de policiar as

\footnotetext{
${ }^{79}$ Relatório do Secretário de Negócios da Justiça relativo ao ano de 1894, Anexo Chefe de Polícia,p.6.
} 
diversões frequentadas pelas nossas classes mais distintas bem como pontos de reunião", que se juntou às doze seções policiais da Força Pública da capital. Iniciava-se assim a organização de um quadro profissional para vigiar as ruas de São Paulo. Com esse aparato, quatro anos depois, em 1898, as ocorrências em São Paulo indicavam cerca de 904 menores detidos, para 8112 maiores. Desse total, 4120 foram considerados analfabetos, mantendo-se praticamente a taxa dos anos anteriores. Em 1900, o quadro de detenções efetuadas nos diversos distritos policiais da capital indicava 1044 menores para 6509 maiores, ampliando-se assim a porcentagem de crianças e adolescentes presos em relação aos adultos, conforme dados extraídos dos Relatórios policiais oficiais.

\section{Crianças e nervos irritados}

O contraponto da criança inserida na escala classificatória abandonadaviciosa-delinquente - para quem o trabalho seria o único elemento a fornecer uma moral que a tornasse viável - era a criança escolarizada, objeto de uma série de estudos realizados visando atenuar os perigos da fadiga intelectual. Em 1904, um manual de Educação Physica ${ }^{80}$ pregava que "o sistema nervoso da criança distinguese por sua grande sensibilidade (...) Deve-se portanto evitar com o máximo cuidado tudo o que pode irritar os nervos da criança e a sua imaginação impressionabilíssima. Certas crianças nascem nervosas, é certo, mas outras, pela

${ }^{80}$ REIS, Álvaro Borges dos. Educação Physica. Salvador, s/e, 1904. 
maior parte, devem este nervosismo à uma educação mal dirigida. A falta de apetite e o sono agitado são dois sintomas muito frequentes nas crianças nervosas".

Para as crianças nervosas, um termo francês: surmenage escolar, termo introduzido oficialmente no português como sinônimo de estafa. O grave problema era definido como o estado de fadiga resultante dos trabalhos escolares e da desproporção entre as faculdades físicas e as intelectuais do jovem aluno e do esforço que lhe seria exigido. Um esforço exagerado, gerado a partir de "desejo, por exemplo, que certas crianças menos dotadas de faculdades assimiladoras que as outras naturalmente favorecidas, manifestam, esforçando-as para suplantarem com a sua aplicação a falta das mesmas faculdades". Nestes casos, cabia aos pais não exigir que um "mediocremente inteligente" buscasse se igualar ao colega "brilhantemente dotado". O pior perigo da surmenage, contudo, estava naquele discípulo de "constituição fraca e de inteligência pouco desenvolvida", que apesar de todo esforço nem mesmo iguala ou alcança o dito colega: "Vêm-lhe em breve a descrença, o descoroçoamento e a depressão moral devidas ao sentimento da sua inferioridade e a subsequente fadiga física e intelectual". A surmenage escolar não se manifestava somente pela fadiga intelectual, pela falta de energia e pelo enfraquecimento moral; poderia também manifestar-se pelas perturbações físicas como a anemia, as palpitações cardíacas, cefalalgias, insônias, perturbações digestivas ou inapetência: "O trabalho intelectual provoca a hiperemia do cérebro, e exagerado, favorece as dores de cabeça. A vida sedentária traz as perturbações da digestão, constipação do ventre, embaraçando demais a atividade do coração e dos pulmões". Propõe-se então a divisão do dia das atividades de uma criança da 
seguinte forma: cinco horas de trabalho intelectual, exercícios físicos e trabalhos manuais; quatro horas e meia de ocupações artísticas; duas horas e meia de recreios de sociedade; nove horas de sono e três horas de alimentação e tempo livre. Era consenso nos manuais de que a surmenage trazia perturbações diversas para o sistema nervoso, daí o regramento proposto. Esta "legislação" sobre o cotidiano escolar não se referia aos excessos impostos às crianças que deveriam trabalhar; o efeito moralizante do trabalho não representaria problema para o sistema nervoso.

Mesmo as inúmeras publicações sobre higiene escolar falavam de uma escola em que os principais problemas eram a miopia e a lordose, e recomendavam que fossem limitadas as horas de bordado para as meninas, além de somente introduzir livros cuja impressão fosse em papel branco. ${ }^{81}$ A higiene escolar falava de uma criança em cujos primeiros anos deveria "respirar o puro ambiente do lar doméstico, gozar as inolvidáveis carícias de uma mãe desvelada e receber os conselhos de um pai amoroso" ${ }^{82}$ Tudo deveria concorrer para "preparar o cérebro do jovem educando sem sacrifício da rijeza necessária para a concorrência da vida" e "esperar pacientemente que todos os órgãos estejam aptos a sofrer as impressões diversas da existência escolar".

A idade geralmente fixada pelos higienistas para as primeiras impressões era de oito anos. Isto porém não quer dizer que antes desse período o espírito da criança não fosse preparado para desembaraçadamente poder mais tarde "encetar os trabalhos didáticos". O campo da higiene pedagógica, ramo da higiene geral, deveria se preocupar principalmente com as moléstias do aparelho visual, desvios

${ }^{81}$ Como é o caso de PATURI, José Lopes. Hygiene infantil, principalmente no capítulo intitulado "Moléstias escolares", 1898.

${ }^{82}$ Como faz COLLET, Agenello Geraque. Hygiene escolar, em 1895. 
da coluna vertebral e constipação do ventre. A falta de educação física era vista já no final do século XIX como a causa mais importante da decadência orgânica da geração moderna ${ }^{83}$ As recomendações iam desde a escolha do local para construção da escola, ventilação e luminosidade, até determinação da altura, em centímetros, dos bancos e mesas, conforme as classes, além de detalhes técnicos sobre a iluminação.

As crianças nervosas também eram alvo de outra preocupação: a histeria infantil, que era considerada de diagnóstico difícil para não ser confundida com bizarrice. Em 1891 João Maria Carneiro de Lyra apresenta tese à Faculdade de Medicina da Bahia intitulada Hysteria Infantil. ${ }^{84}$ Segundo ele, metade da mães histéricas davam origem a histéricos. Em todos os períodos da vida poderia explodir esta nevrose, com predominância nas meninas. Entre as causas da histeria infantil havia algumas direções nas especulações: “emoções morais gozam de um papel saliente entre as causas produtoras desta nevrose. As histórias fantásticas narradas a uma criança tenra com o fim de fazê-la dormir ou de impedir o choro são poderosos contingentes para a explosão dessa nevrose. As comoções provocadas por uma notícia desagradável ou por uma paixão não satisfeita, ou o espiritismo, tem concorrido, pela impressão que causa nas funções psíquicas das crianças, para a produção dessa enfermidade". As crianças histéricas eram definidas pela impressionabilidade: "nelas a cólera e a alegria são de uma instabilidade extraordinária. A causa mais insignificante é muitas vezes suficiente para despertarlhes violentas paixões: a recusa na satisfação de um capricho é o bastante para ${ }^{83}$ LOBO, Francisco Candido da Silva Lobo, Apontamentos para o estudo da Hygiene escolar, 1895.

${ }^{84}$ LYRA, João Maria Carneiro de. Hysteria Infantil, 1891. 
tranformar-lhes o prazer que gozam em uma cólera violenta. Esta extrema vivacidade do espírito, esta hiperestesia psíquica as conserva numa agitação contínua: não podem ficar tranquilas senão por um instante, não têm perseverança e deixam com facilidade o trabalho principiado com sofreguidão. O capricho, a indecisão e a bizarria são as anomalias que caracterizam sua vontade; são na maior parte inteligentes, compreendem com facilidade e imitam bem. (...) Em geral são vaidosas e coquetes; gostam de andar bem vestidas, exagerando para isso seus enfeites. Procuram atrair a atenção das pessoas que as cercam, exagerando seus atos ou sofrimentos", descreve o médico.

A sobrecarga intelectual também poderia aparecer sob a forma de neurastenia, cujo caráter era permanente e não transitório como o da histeria. Quanto ao prognóstico, a histeria poderia desaparecer de um dia para o outro ou levar até anos, "principalmente se a família do doente for solicitada em satisfazerlhes os caprichos, o que vem a dar no mesmo que prolongar-lhes a doença". A profilaxia deveria ser dirigida ao momento da gravidez, já que a moléstia é essencialmente hereditária: "uma mulher histérica deve se subtrair, durante o tempo da gestação, de qualquer causa que lhe perturbe o sistema nervoso. Alguns sugerem que as mães recorram a uma ama robusta. As crianças descendentes de neuropatas devem ser educadas em internatos e evitar todos os atos emocionadores. Os passeios ao ar livre, a ginástica, a natação e a equitação concorrem poderosamente para o robustecimento do sistema nervoso. A hidroterapia tem produzido resultados favoráveis com infusão de certas plantas aromáticas. Há ainda propostas de tratamento com eletricidade estática (aconselhado por Charcot), morfina, 
hipnotismo (Charcot cita o fato de uma criança ter se tornado histérica após ensaios de hipnotismo feitos por seus companheiros de internato)".

No âmbito desta pesquisa, cabe ressaltar as oposições que surgem na construção de dois discursos distintos em torno da infância: um primeiro aponta o trabalho como a única solução para crianças em "perigo moral". Nesse caso, não haveria surmenage ou qualquer conotação de excesso que levasse a um prejuízo do sistema nervoso. Por outro lado, a sobrecarga intelectual é apontada como problema para o grupo de crianças escolarizadas, para quem novos saberes e práticas surgem tanto para a prevenção como para a administração do cotidiano escolar.

Vejamos agora quais os caminhos trilhados pelo discurso científico quando o objeto em foco é a criança criminalizada, aquela que permanece recusando o mundo do trabalho como salvação moral. 


\section{Discernimento e recapitulação: a psicologia criminal contra a 'psicolástica'}

A demonstração da teoria da evolução no século XIX reconfigurou o mundo da vida. A doutrina da seleção natural recusava mudanças revolucionárias e caracterizava o progresso humano como um lento, natural e inevitável processo de evolução, e teve ecos significativos no campo da criminologia. Uma leitura peculiar de Darwin foi realizada por Ernst Haeckel (1834-1919), ao proclamar que todo indivíduo passa por uma série de estágios que correspondem às diferentes formas adultas de seus antepassados: sua teoria foi chamada "a recapitulação". ${ }^{85}$ Fundamentalmente, a recapitulação abriu campos para o estabelecimento de diferenças hierárquicas entre grupos humanos. Adultos de grupos considerados inferiores deveriam ser como crianças de grupos superiores, pois a criança representaria um ancestral adulto primitivo.

Autonomeando-se introdutor no Brasil da obra do zoólogo alemão, Tobias Barreto passou a utilizar a expressão "psicologia criminal" na construção de uma teoria da imputação, entendendo o direito como o princípio da seleção legal, ou

\footnotetext{
${ }^{85}$ Segundo Gould, a partir da biologia o conceito de recapitulação expandiu-se para várias outras disciplinas, constituindo-se numa das idéias mais influentes da ciência do final do século XIX. Segundo ele, tanto Sigmund Freud quando Carl Jung eram firmes partidários da recapitulação, e a idéia de Haeckel desempenhou um papel bastante importante na teoria psicanalítica, como por exemplo em Totem e Tabu. Ver GOULD, S. J. A falsa medida do homem, 1991, p.112.
} 
seja, o processo de adaptação das ações à ordem pública, promovendo uma espécie de seleção jurídica pela qual os membros corruptos da sociedade seriam postos à parte do organismo social. Escreve Tobias: "o direito é a disciplina das forças sociais, o princípio da seleção legal [grifos no original] na luta pela existência. De acordo com a filosofia monística e com os dados da ciência moderna, posso ainda defini-lo - o processo de adaptação das ações humanas à ordem pública, ao bem estar da comunhão política, ao desenvolvimento geral da sociedade". ${ }^{86}$

Nesse processo inevitável de adaptação das ações à ordem pública as crianças criminosas tornam-se objeto do discurso criminológico ao lado dos loucos. ${ }^{87}$ Ao publicar Menores e loucos em Direito Criminal em 1884, Tobias Barreto abre uma nova fase no debate entre novas e velhas elites em torno da imputabilidade. A teoria da imputação, ou psicologia criminal, como a denominavam os juristas alemães, apoiava-se no fato empírico considerado indiscutível de que o homem "normal", chegando a uma certa idade legalmente estabelecida, adquiriria a capacidade para reconhecer o valor jurídico de seus atos. Restava definir qual idade seria esta, ou seja, a partir de qual idade uma criança seria capaz de reconhecer o valor jurídico de seus atos, e - fundamentalmente - se esta idade seria a mesma não importando quais fossem as condições em jogo. Como a ciência definiria essa capacidade?

Conforme o Código Criminal de 1830, a imputabilidade era aplicável a partir dos 14 anos incompletos, desde que a criança tivesse agido com discernimento, o

\footnotetext{
${ }^{86}$ BARRETO DE MENEZES, Tobias. Menores e loucos em direito criminal [1884] 1951, p.34.

${ }^{87}$ A crítica realizada por Tobias Barreto afirmava que o código do Império reunia sob a noção geral de "irresponsabilidade" classes diferentes de sujeitos. É na crítica a essa falta de especificidade que ele introduzirá a discussão sobre o discernimento. Conforme ALVAREZ, Marcos Cesar. A emergência do Código de Menores de 1927, 1989, p.71.
} 
que significava não haver imputabilidade absoluta, ou seja um limite fixo de imputabilidade: ${ }^{88}$ "Depois da proclamação da Independência, os termos menor e menoridade foram utilizados pelos juristas na determinação da idade, como um dos critérios que definiam a responsabilidade penal do indivíduo pelos seus atos. $\mathrm{O}$ Código Criminal do Império de 1830, através de seus artigos definiu, de fato, três períodos de idade antes dos 21 anos, com respeito à responsabilidade penal e às penas. Primeiro, os menores de 14 anos não têm responsabilidade penal, o que só terá validade para os escravos a partir de 1885. Segundo, os maiores de 14 e menores de 17 anos, que 'poderá o juiz parecendo-lhe justo, impôr-lhe as penas de cumplicidade'. Terceiro, o limite de 21 anos para a imposição de penas drásticas como as galés, que será estendida também aos maiores de sessenta. Contudo, estabelecendo-se que os menores de 14 anos atuavam com discernimento, o código admitia que fossem recolhidos a casas de correção a critério do juiz, até os 17 anos. Isso permitiria que os menores de 17 anos fossem condenados, sendo a prisão comum o destino das crianças, já que só no fim do século surgem as casas de correção para menores". ${ }^{89}$

Em seu argumento, Tobias Barreto buscava negar a legitimidade dessa divisão em idades biológicas na determinação da imputabilidade penal do criminoso. O fator determinante da imputabilidade seria, segundo ele, a "cultura espiritual", único elemento a partir do qual seria possível diferenciar o certo do errado. A lógica exigia que Tobias acabasse por pedir um limite para a

\footnotetext{
${ }^{88}$ O modelo brasileiro não acompanhava a legislação americana. Uma revisão do código penal norteamericano em 1827 elevou a idade de responsabilidade penal de 7 para 10 anos, e quatro anos depois crianças menores de 18 anos foram excluídas do sistema penitenciário. Conforme PLATT, Anthony M. The child savers, 1977, p.102.

${ }^{89}$ LONDOÑO, Fernando Torres. "A origem do conceito 'menor"”. In: PRIORI, Mary del (org.) História da criança no Brasil, 1995, p.130.
} 
imputabilidade penal, reagindo contra o peso dado ao procedimento baseado no discernimento, entendido como a faculdade de distinguir o verdadeiro do falso, o bom do mal. Sua tese baseava-se no péssimo sistema de ensino do país, afirmando que não proporcionava o instrumental necessário para o exercício da vida social plena, ou seja, a adaptação das ações à ordem pública.

Tobias inspirar-se-ia aí na jurisprudência etnológica, mantendo suas idéias basilares apreendidas na obra de Jhering, em que o direito é entendido como um meio de abolir o estado de natureza, antítese da cultura. Escreve Tobias: "Mais tarde, ver-se-á nela [na pena], em nome de Darwin e Haeckel, alguma cousa semelhante à seleção espartana, ou uma espécie de seleção jurídica, pela qual os membros corruptos vão sendo postos à parte do organismo social comum". ${ }^{90}$

A "psicologia criminal" de Tobias Barreto questionava a versão evolucionista de Spencer, marcada pelo elogio ao individualismo e ao capitalismo liberal, deduzido do transformismo contido na sobrevivência do mais apto. A vasta teoria do progresso trazida por Spencer, sua noção de aperfeiçoamento indefinido do indivíduo, condizia com os interesses de uma nova classe de bacharéis e doutores libertados das crenças teológicas. Em um período considerado de excepcional desenvolvimento da vida econômica brasileira, as profissões liberais passaram a constituir uma nova espécie de foro de nobreza. $\mathrm{O}$ spencerismo correspondia perfeitamente aos desejos desses novos nobres do pensamento social ao sul do país. Para Spencer, a superioridade mental - e moral - consistia na precisão e fineza cada vez mais perfeitas das reações de um animal a seu meio, o que o levaria a condenar qualquer intervenção humana para impedir os efeitos da lei

${ }^{90}$ BARRETO DE MENEZES, Tobias. Menores e loucos em direito criminal [1884] 1951, p.35. 
da sobrevivência do mais apto, tal como a caridade. Nesse darwinismo social, havia também lugar para a recapitulação, pois segundo Spencer, os traços intelectuais dos selvagens poderiam ser observados nas crianças dos povos civilizados.

O germanista Tobias Barreto, por outro lado, criticava o uso - que considerava indiscriminado -, do termo evolução, afirmando que a idéia contida na teoria evolucionista surgira bem antes do darwinismo. Para ele, os conceitos de "transformação" e "melhoramento" já eram comuns principalmente entre os alemães, que utilizavam o termo Entwicklung (desenvolvimento), o qual traduziria todos os fenômenos discutidos por franceses e ingleses, positivistas e spencerianos. ${ }^{91} \mathrm{Na}$ obra de Haeckel, Tobias Barreto encontrou explicação para o que considerava o processo de evolução emocional e mental do homem, fundamental para construção de sua psicologia criminal. Haeckel propunha uma relação causal baseada na herança, entre a ontogenia e a filogenia, ou seja, entre a história do indivíduo e de sua série ancestral. A teoria da recapitulação assim construída explicava os sonhos como velhos medos da raça. Seguindo a lógica, o beijo teria se desenvolvido como uma evidência de que a pessoa não seria comida pelo outro. A tendência das crianças de correr seria entendida assim como um eco do impulso migratório dos ancestrais.

Do ponto de vista desta versão da biologia, as transformações na infância passariam por uma série de tipos, desde o protozoário até o homem. No momento da concepção seria uma estrutura unicelular, na segunda semana sugere um tipo

\footnotetext{
${ }^{91}$ A teoria darwinista da evolução não impressionava porque este conceito fosse novo - pois já era familiar há décadas - mas porque fornecia, pela primeira vez, um modelo de explanação satisfatório para a origem das espécies, e o fez em termos que eram inteiramente conhecidos até para não-cientistas, já que refletiam os conceitos mais familiares da economia liberal, ou seja, a competição. Conforme HOBSBAWM, E. A era do capital, 1997, p.353.
} 
invertebrado e assim por diante. Gradualmente o feto assumiria um ar antropomórfico. O que importa salientar é: qualquer interferência nesse processo resultaria em desastre. Nesse contexto, o crime passa a ser entendido como uma clara manifestação do princípio naturalizado da hereditariedade, e não um fenômeno mórbido, como pretendia Nina Rodrigues, ${ }^{92}$ inspirado pelo positivismo italiano, aplicado sobretudo ao direito penal. Escreve Tobias: "Eu considero o crime uma das mais claras manifestações do princípio naturalístico da hereditariedade, e como tal, quando mesmo ele fosse o que os sentimentalistas liberalizantes pretendem que seja, quero dizer, um fenômeno mórbido, um resultado de doença, nada proibia que, também neste domínio, como em todos os outros da natureza, a adaptação procurasse eliminar as irregularidades da herança". 93

A recapitulação como chave para o entendimento da "evolução psíquica" na infância opera uma nova interpretação do crime praticado por crianças. Também em outros trabalhos desenvolvidos no Recife é possível apontar esses pressupostos, como por exemplo a tese apresentada à faculdade de Direito por Tito dos Passos Rosas Filhos, intitulada Da responsabilidade dos menores. ${ }^{94}$ Ao questionar até que idade a criança é completamente irresponsável, o autor argumentava da seguinte forma: “É incontestável que não se pode por de lado a evolução psíquica dos seres; o senso moral, a inteligência, o caráter não se formam de improviso.(...) Haverá por aí quem ignore que a consciência se desenvolve por meio de um processo lento que pode ser apressado, retardado ou mesmo paralisado por uma quantidade

\footnotetext{
${ }^{92}$ Sobre Nina Rodrigues, ver capítulo seguinte.

${ }^{93}$ BARRETO DE MENEZES, Tobias. Menores e loucos em direito criminal [1884] 1951, p.34-35.

${ }^{94}$ ROSAS FILHO, Tito dos Passos, Da responsabilidade dos menores. Dissertações e Theses apresentadas á Faculdade de Direito, 1895.
} 
considerável de fatores que direta ou indiretamente vêm influir sobre a psyche do indivíduo? Quem não sabe que esta psyche é uma resultante de fatores diversos, de causas múltiplas que atuam no indivíduo? Sustentar o contrário é indício de insanidade mental. (...) Dou como assentado que o desenvolvimento do indivíduo recapitula o desenvolvimento da espécie, que a ontogênese é um apanhado da filogênese. Todos sabem que pontos de contato existem entre a criança e o selvagem, que semelhanças se descobrem entre esses pequeninos seres imprevidentes e descuidosos e os habitantes das cavernas. (...) É sabido que na criança dominam as sensações; as idéias, as noções das cousas, só lentamente são adquiridas. (...) Seria uma falta imperdoável passar aqui em silêncio sobre a influência que a hereditariedade exerce sobre a firmação da consciência, do caráter do indivíduo."

O caráter é aqui entendido como um organismo, cuja formação e desenvolvimento devem ser estudados com todo o rigor científico: "Todos sabem que o caráter é uma espécie de organismo tendo uma formação e um desenvolvimento próprios sobre que atuam influências diversas, naturais e sociais. (...) O caráter individual é constituído por duas partes principais, uma fundamental, outra adventícia: a primeira resulta do lento depósito e do acúmulo de elementos que se formam na série de gerações de que o indivíduo descende; a adventícia é a que se acrescenta no período da vida individual. A parte fundamental é a hereditária. Sobre ela se acumula tudo o que se forma no curso da vida."

Sob a ótica da recapitulação, este organismo entendido como caráter seria formado desde o nascimento, a partir de uma divisão do cérebro: "O cérebro do 
recém-nascido cinde-se em duas partes. Uma destas partes, é aquela que as gerações passadas nos transmitiram com um arranjo especial, uma tendência de certo modo definida (...) Contraposta a esta existe a outra parte do cérebro, mais pessoal, mais autonômica, tendo feição mais própria. Composta de elementos nervosos esta parte do cérebro é destinada ao armazenamento das sensações (...) Firmado nesses elementos o cérebro chegará mais tarde por uma síntese, à noção do bem e do mal. Esta evolução do caráter se dá lentamente. (...) O que é certo é que não há parte do cérebro que não esteja sujeita a influência daquela grande lei da evolução. A evolução da psyche molda o caráter", conclui o jurista.

A partir dessas premissas o autor argumenta que os juristas abandonavam o que chama de "lado psicológico" da questão, que seria justamente colocado pelos limites do discernimento. Criticando o italiano Garofalo - e por tabela juristas brasileiros aderentes às teses da criminologia italiana -, que dizia reconhecer um criminoso nato em um recém-nascido, o autor se coloca contra o que acusa de "moda biológica". Para ele, eliminado o livre arbítrio, não se poderia falar em imputabilidade moral, pois "a imputabilidade é uma relação psicológica e ética. (...) Como elevar-se a psicologia à altura de ciência, banindo toda e qualquer lei reguladora da vontade? Quem já viu ciência sem leis? (...) Não existindo delito fora da causalidade psicológica, ninguém seria completamente imputável". Os argumentos procuravam questionar a validade da determinação do discernimento sem a consideração do livre-arbítrio, elemento jurídico imerso no que então era chamado "causalidade psicológica". 


\section{Uma ciência contra a "psicolástica"}

O monismo - filosofia materialista do alemão Haeckel, que inspirou o brasileiro Tobias em importante fase de sua vida intelectual -, atacava o que chamava de "psicolástica", uma psicologia que permanecia, segundo ele, rudimentar. Para o alemão, a psicologia não era ainda a verdadeira ciência empírica do espírito, a saber, uma fisiologia do órgão da alma, não passando de metafísica fantástica, formada por uma introspecção impossível de classificar, com comparações desprovidas de espírito crítico, observações mal compreendidas, experiências incompletas, erros especulativos e dogmas religiosos. Acusava a maioria dos chamados psicólogos de sequer conhecerem a estrutura do cérebro ou dos órgãos dos sentidos, os únicos que permitiriam a atividade psíquica, tanto no homem como nos outros animais. Influenciado por esse germanismo, Tobias não se desembaraçaria do monismo nem mesmo com a ascendência crescente da influência neokantiana em sua última fase de pensamento. ${ }^{95}$ Entretanto, é preciso entender a recepção do kantismo em Tobias via Hermann von Helmholtz (1821-1894), fisiologista e físico alemão, ocupante da primeira cadeira autônoma de fisiologia em Heidelberg, que interpretava o sujeito kantiano num sentido eminentemente psicofisiológico e cuja epistemologia era uma fisiologia dos sentidos. Contra uma concepção realista ingênua, e referindo-se ao Kant da Crítica da razão pura,

\footnotetext{
${ }^{95}$ Conforme a análise realizada por COSTA, João Cruz Costa. Contribuição à história das idéias no Brasil, 1956
} 
Helmholtz mostrou que a sensação está ligada a uma certa modificação do organismo e não a qualidades próprias do mundo. ${ }^{96}$

Uma espécie de idolatria pela ciência caracterizou este materialismo vulgar. Na Alemanha do fim de século XIX, os pensadores orientaram-se de preferência para o monismo naturalista, segundo alguns porque Haeckel tinha pouco lastro de erudição histórico-filosófica, ostentando um encanto fácil, caracterizado pela idéia ingênua de que para toda questão racional há uma resposta indubitável, sobretudo por parte da ciência natural. Segundo Cruz Costa, o que animou o grupo de Recife foi um germanismo de segunda ordem, no qual tem posição destacada Ludwig Noiré, autor que seria completamente desconhecido para as novas gerações.

Tobias Barreto pertenceu ao grupo de homens que, através das Academias, tomou parte da vida pública e intelectual configurando a nova sociedade "republicana" que viria. Moço e pobre, Tobias partira de Itabaiana, onde ensinava latim, com destino à Bahia, a fim de ingressar no seminário, única saída além da Escola Militar que poderia levar a uma vida de estudo. Formado em direito em Recife em 1869, conquistou uma cátedra em 1882 e lá permaneceu até sua morte em 1889. Nos primeiros anos, o feitiço do romantismo não foi de todo quebrado, mas já na década de 70 lançava-se em uma feroz campanha contra o ecletismo. Os defensores de um catolicismo militante, em 1880, estavam em minoria no Recife.

O entusiasmo de Tobias pelo germanismo levou-o a publicar numa cidadezinha em que o número de analfabetos devia ser elevado, um jornal em língua alemã, escrito e composto por ele, e muito provavelmente somente por ele lido. Nos anos seguintes Recife passaria a abrigar um núcleo de jovens intelectuais, cujo

\footnotetext{
${ }^{96}$ Conforme BRAUNSTEIN, J-F e PEWZNER, É. Histoire de la psychologie, 1999, p.83.
} 
integrante Silvio Romero, tempos depois, batizaria de "Escola do Recife". A publicação de Menores e loucos em Direito Criminal em 1884 está ligada à última fase de sua obra, marcada pelo rompimento com o positivismo, e que representa um momento posterior à crítica ao ecletismo espiritualista ancorada na adesão parcial à doutrina de Comte.

A análise realizada por Tobias Barreto em Menores e loucos marca, portanto, o último elo de um momento de transição, em que novas teses sobre a criminalidade passam a salientar o caráter permanente e irreversível do comportamento criminoso, anunciando a aceitação de um modelo médico, particularmente no caso da correção de crianças e adolescentes: o crime como consequência de patologia. Raça passa a ser uma elemento-chave a partir da qual se reconstruiu o discurso sobre o crime praticado por crianças, abrindo caminho para categorias como precocidade e perversidade na explicação da infância criminalizada. Apesar da influência intelectual exercida pela Escola do Recife no pensamento social brasileiro, o Código Republicano de 1890 instituiu a idade de 9 anos como limite mínimo para a responsabilidade penal, seguindo o modelo italiano, e inaugurando na República uma legislação penal e uma ação intensamente repressiva e policial na invenção do "menor infrator". Na calda desta decisão jurídica, instituições foram criadas para tratar da nova categoria jurídica que surgia: o menor delinquente, que não mais seria enviado à prisão comum, mas passaria a ser ser alvo de uma ação científica que visava atenuar os males da degeneração. 
Os argumentos de Tobias Barreto estavam no limiar da revisão da criminologia clássica, para quem cada indivíduo seria responsável por suas ações e todos seriam iguais perante a lei, por isso seriam inadmissíveis circunstâncias atenuantes. Como teoria de controle social, a criminologia clássica não explicita teorias sobre motivação humana, mas fixa a forma pela qual o Estado deve reagir diante do delinquente ao mesmo tempo que define os desvios que permitem qualificar de delinquentes determinadas pessoas. ${ }^{97}$

Entretanto, já no revisionismo neo-clássico questiona-se a fixação no ato delituoso e o menosprezo em relação às diferenças individuais. Juristas neoclássicos passaram a considerar antecedentes penais na situação particular de cada delinquente, e introduziram reformas para dar conta destas questões, principalmente no que se refere às circunstâncias atenuantes, dando atenção ao meio físico e social em que se encontrava o delinquente. Fundamentalmente, os juristas passariam a salientar fatores patológicos como a demência e a conduta impulsiva, que excluía a premeditação.

O homem delinquente não é mais o indivíduo isolado do período clássico da criminologia. Sob a nova configuração, os princípios da criminologia clássica passam a ter como objeto apenas os homens "normais", ou seja, mentalmente sãos e considerados plenamente responsáveis por seus atos. Como consequência desse argumento, a revisão do classicismo traz pela primeira vez as crianças (e também em certa medida os idosos) como um grupo populacional menos capaz de tomar decisões com responsabilidade. Por outro lado, os loucos passam a ser considerados

\footnotetext{
${ }^{97}$ Conforme TAYLOR, I e outros. La nuova criminologia, 1997, p.20.
} 
um grupo totalmente a parte, incapazes de uma conduta adulta livre, pois têm suas ações absolutamente determinadas pela patologia. Menores e loucos em direito criminal, de Tobias Barreto, é exemplar representativo dessa transição.

Nessa trajetória de revisão da criminologia clássica, a pena passa a assumir cada vez mais uma função reabilitadora. A revolução positivista na criminologia, iniciada por Enrico Ferri, desloca o objetivo da criminologia clássica, que não mais deveria estar focalizada na redução das penas e sim na diminuição dos delitos. ${ }^{98}$ Suas disputas, no entanto, apontam para duas vertentes: o positivismo liberal e o positivismo radical. Os positivistas liberais pretendiam estabelecer um padrão moral sobre o qual edificar uma ciência positiva, destinada em última instância a reduzir o comportamento criminoso. Acreditáva-se na existência de um consenso mais ou menos difundido sobre a natureza da moralidade e que esta poderia ser descrita por qualquer grupo heterogêneo, sendo possível reformar a legislação dessa forma.

O positivismo radical, por sua vez, apresenta duas versões. Uma versão atenuada entendia as normas legais como representativas de um consenso. Sob esta premissa, seria procedente reunir estatísticas próprias segundo esse padrão, mas com independência da polícia e do sistema judicial. A versão mais forte apoiava-se em estatísticas que indicavam um suposto consenso que diferiria significativamente daquele consagrado nas legislações penais. Nesta concepção, o delito se manifestaria em todos os setores da sociedade, entre ricos e pobres, jovens e velhos, homens e mulheres e sempre em níveis supostamente mais altos e proporções diferentes àquelas apresentadas pelas estatísticas não-científicas. Isso se devia ao

\footnotetext{
${ }^{98}$ É importante distinguir aqui o positivismo que certa criminologia emprega daquele que aparece na teoria social, uma vez que o positivismo criminológico se constituiu mais claramente com vistas a sua aplicação prática. Argumento defendido por TAYLOR, I e outros. La nuova criminologia, 1997.
} 
caráter determinado do sentimento moral, que limitava o poder de escolha do homem. Os positivistas recusaram totalmente a noção clássica do livre arbítrio, e a conduta criminosa passou a ser entendida como submetida a leis causais. Uma das mais famosas dessas leis diz: “assim como em um volume determinado de água, a uma dada temperatura, é possível dissolver uma quantidade fixa de qualquer substância química, nem um átomo menos, em um meio social determinado, em que o indivíduo se acha em condições físicas definidas, se observa a presença de uma quantidade fixa de crimes".99

O determinismo do comportamento do positivismo radical levaria até um limite máximo a incorrigibilidade. Lombroso escreveria em 1913: "Seria um erro imaginar medidas que pudessem ser aplicadas com êxito aos criminosos natos, porque estes, em sua maior parte, são refratários a todo tratamento, inclusive ao carinho mais intenso dado desde o berço". ${ }^{101}$ Comparando criminosos atávicos com animais, os selvagens com as pessoas de raças inferiores, Lombroso reproduz o argumento básico da recapitulação. A criança, como um antepassado adulto, é um primitivo vivo, em quem brotam as manifestações criminosas mais sádicas: “Quem vive entre as classes superiores nada sabe da paixão que sentem as crianças pelas bebidas alcóolicas, mas nas classes baixas é coisa comum verificar que até as

\footnotetext{
${ }^{99}$ FERRI [1895], citado por TAYLOR, I e outros. La nuova criminologia, 1997, p.41.

100 Apesar dos estudos experimentais de Lombroso não terem sido traduzidos para o inglês até 1911, acadêmicos americanos tiveram contato com suas concepções desde 1890, e sua popularidade, bem como a de Spencer, estava baseada no fato da existência de uma "classe criminosa". Conforme PLATT, Anthony M. The child savers, 1977, p.20.

${ }^{101}$ LOMBROSO [1913], citado em TAYLOR, I e outros. La nuova criminologia, 1997, p.43. Conforme os autores, uma voz dissonante da época foi Durkheim, cuja obra expõe elementos de explicação social em um momento em que a ciência e as escolas positivas estavam unidas na bandeira do individualismo. Para ele, o delito seria um fato social, uma parte normal da sociedade que não poderia ser simplesmente "arrancada". Cabe aqui um comentário sobre a posição de Marx a respeito do crime. Em contraposição aos positivistas, Marx afirma que é possível uma sociedade livre de delitos, demonstrando a interdependência entre relações sociais de produção capitalista e o delito.
} 
crianças de peito bebem vinho e outras bebidas alcoólicas com notável prazer". ${ }^{102}$ É notável ainda que entre os estigmas atávicos apontados por Lombroso figurasse a gíria dos criminosos, uma linguagem própria com elevado número de onomatopéias, que ele associava à fala de crianças e dos selvagens. O criminoso seria dotado de um grave defeito no desenvolvimento moral, e seria como uma criança pequena, instintivamente agressiva e precoce. Por isso o criminalista defendia a necessidade de um exame antropométrico nas escolas, pois traços como o pequeno tamanho da cabeça ou o tamanho exagerado do rosto poderiam explicar falhas escolares e principalmente disciplinares de certas crianças.

Veremos agora quais as consequências da recepção de Lombroso na emergência da criminologia brasileira, e em que medida o positivismo criminológico provocou a aceitação de um modelo médico de modificabilidade que reconfigurou a infância criminalizada.

${ }^{102}$ LOMBROSO [1895], citado por GOULD, S. J. A falsa medida do homem, 1991, p.126. 


\section{Impulsividade e precocidade: a psicologia mórbida das}

\section{raças}

No final do século XIX, a discussão em torno da prefixação de um período de irresponsabilidade apontava para três 'escolas' que orientavam os juristas. Para criminalistas preocupados fundamentalmente com diferenças individuais, seria prejudicial a determinação de um período de irresponsabilidade absoluta, de forma que cada caso deveria ser examinado e resolvido como tal. Era o caso da escola de Ferri e Lombroso, que sustentava um certo 'regionalismo jurídico', baseando-se na hipótese de que a responsabilidade dependia necessariamente de fatores como hereditariedade, 'raça' e 'clima'. Outros sustentavam ser necessária essa prefixação, argumentando que a quase totalidade dos países a adotava, com exceção da Turquia e da França. Esta 'escola' admitia a dificuldade em fixar uma idade, mas defendia sua necessidade. A prefixação deveria, porém, ser graduada, sendo portanto imprescindível uma divisão da vida humana em períodos: um de responsabilidade presumida, outro de responsabilidade duvidosa e um terceiro em que ela seria nula. Segundo os próprios autores, esse sistema considerava fundamentalmente o que era 
chamado "lado psicológico" da questão, ou seja, uma relação primordial entre imputabilidade e discernimento, conforme vimos no capítulo anterior. Havia ainda uma terceira corrente, formada por juristas eminentemente pragmáticos, que não questionava a responsabilidade da criança criminosa, mas limitava-se a analisar que medidas a sociedade deveria tomar para conter o crime praticado na infância.

Nina Rodrigues (1862-1906), um dos primeiros no campo da medicina legal no Brasil, defendeu uma diminuição da idade em que as crianças deviam ser consideradas responsáveis penalmente. Negros ou mestiços, já que não havia brancos nessa análise, ${ }^{103}$ os meninos delinquentes que Nina Rodrigues submetia à análise na penitenciária da Bahia deviam ser considerados mais responsáveis do que os próprios adultos para os quais ele propunha em certos casos a indulgência da lei. Essa criminologia diferencial estava baseada no crença de que, segundo ele, "a observação, confirmando as induções da biologia, demonstra que o desenvolvimento mental é muito mais rápido, a maturidade muito mais precoce nas raças inferiores do que nos povos cultos ou civilizados". ${ }^{104}$

${ }^{103} \mathrm{O}$ jovem mulato Nina Rodrigues foi o primeiro pesquisador a estudar a influência africana de maneira sistemática. Tentou uma cuidadosa catalogação das origens etnográficas africanas dos escravos trazidos ao Brasil, e procurou identificar os grupos linguísticos primários. Embora tenha morrido aos 44 anos, já havia estreitado relações com pesquisadores de Nova Iorque e Paris, além de ser respeitado nos altos círculos científicos brasileiros. É importante ressaltar também que nem por isso ele entendia o problema negro no Brasil a partir do paradigma norte-americano, ou seja, suas teorias não eram compatíveis com a defesa da escravidão feita por senhores de escravos daquele país. Conforme SKIDMORE, T. E. Preto no branco. Raça e nacionalidade no pensamento brasileiro, 1989, p.74-78.

${ }^{104}$ RODRIGUES, Nina apud CORRÊA, Mariza. As ilusões da liberdade. A escola Nina Rodrigues e a Antropologia no Brasil, 1998, p.176. 
Para Nina Rodrigues, “o estudo das raças inferiores tem fornecido à ciência exemplos bem observados dessa incapacidade orgânica e cerebral". ${ }^{105}$ Ao criticar Tobias Barreto - que publicara Menores e loucos em Direito Criminal em 1884 e via no grau de instrução um meio de aferir o grau de responsabilidade de crianças -, Em seus textos, Nina Rodrigues citava vários autores italianos que procuravam demonstrar com estatísticas criminais a não-verdade da idéia de que para cada escola que se abre, fecha-se uma prisão. Os atos humanos seriam condicionados pela educação apenas até certo ponto, ou seja, até o limite em que passam a vigorar as leis biológicas da natureza humana. Isto porque, para ele, "o crime era principalmente função do senso moral e o desenvolvimento do senso moral precede o da inteligência”. E propunha também - contrariando Tobias, que era a favor de um limite fixo para a menoridade - a indeterminação desse limite e a substituição pelo "exame do discernimento" não importando qual a idade da criança em jogo. Nina Rodrigues defendia as vantagens sociais de tal procedimento, afirmando que quanto mais baixa fosse a idade em que a ação da justiça, ou melhor do Estado, se exercesse sobre os menores, maiores possibilidades de êxito teria.

Para justificar suas teses, Nina Rodrigues relata o caso de um menino que teria assassinado o pai aos nove anos, "obrando com discernimento" e cuja verdade

105 RODRIGUES, Nina. As raças humanas e a responsabilidade penal no Brasil [1894]1938, p.51. O suposto vínculo entre a degeneração e o ordenamento hierárquico das raças deixou-nos um legado curioso. A denominação idiotia mongólica, ou mongolismo, para nos referirmos à desordem cromossômica cuja designação precisa é síndrome de Down. John Langdon Down identificou essa síndrome em um artigo intitulado "Observações acerca de uma classificação étnica dos idiotas", publicado em 1866. Segundo Down, muitos "idiotas" apresentavam traços anatômicos que, embora ausentes em seus pais, coincidiam com certos traços típicos de raças inferiores. Assim, identificou idiotas de variedade etíope, enquanto outros aproximavam-se da "grande família mongólica". Para Down, o fato de certas crianças européias apresentarem traços étnicos mongóis só poderia ser fruto da degeneração. 
sobre o crime ele descobrira através da hipnose. ${ }^{106}$ Segundo Mariza Corrêa, ele criticava assim o novo código da República, que mandava colocá-las em “estabelecimentos agrícolas especiais", que não existiam até então. Os criminosos precoces tampouco deveriam ir para a prisão, que por sua vez, merecia também o voto contrário de Nina, propondo em seu lugar o asilo, aos moldes do projeto criminalista italiano. ${ }^{107}$ Doentes que eram, os criminosos deveriam receber "tratamento" conforme modelo médico, e não ser encarcerados no sistema prisional considerado "pouco científico". Como se percebe das críticas de Nina Rodrigues, o Código Penal de 1890 não incorporou as tendências consideradas então inovadoras que o universo jurídico-penal apresentava. E nem poderia ser entendido como o desdobramento lógico do novo regime político republicano que se implantava: "Foi antes o resultado de um 'amadurecimento' de várias críticas que vinham sendo desenvolvidas desde meados do século, mas principalmente a partir de 1870 , em relação às penas e a sua aplicação, previstas no Código do Império". ${ }^{108}$ Sua decretação em 1890, antes mesmo da entrada em vigor da Constituição, constata a

\footnotetext{
106 Um século separa Mesmer de Charcot, mas o segundo foi o responsável pelo reconhecimento da hipnose pela Academia de Medicina Francesa, em 1882. A partir de então, revistas não somente médicas, mas filosóficas e mesmo literárias estão repletas de artigos sobre hipnotismo. Conforme BRAUNSTEIN, J-F. e PEWZNER, Évelyne. Histoire de la psychologie, 1999, p.96.

${ }_{107}$ Segundo o argumento desenvolvido por Marisa Corrêa, nos últimos anos da vida de Nina Rodrigues o lado psicológico dos problemas que analisava parecem ter assumido cada vez mais o primeiro plano em suas preocupações, abrindo todo um novo capítulo de interesse em sua biografia intelectual. Essa passagem representa um deslocamento da atenção dos aspectos fisiológicos para os aspectos psíquicos do comportamento, o que, segundo Mariza Corrêa, parece não ter sido bem compreendido por aqueles que se diziam seus seguidores. Cf. CORRÊA, Mariza, As ilusões da liberdade. A escola Nina Rodrigues e a Antropologia no Brasil, 1998.

${ }^{108}$ SALLA, Fernando. As prisões em São Paulo, 1999, p.145.
} 
certa independência das suas características em relação ao quadro político formal do período.

Em As raças humanas e a responsabilidade penal no Brasil, publicado em 1894, Nina Rodrigues reafirma como imprescindível ao seu trabalho o conhecimento dos princípios fundamentais do que chamava "psicologia moderna". ${ }^{109}$ Mas que psicologia era essa? Qual seria a "psicologia antiga" para a qual Nina Rodrigues dirigia suas críticas? Para ele, "as leis gerais do desenvolvimento mental no seu mecanismo filogenético constituem os princípios básicos e fundamentais da psicologia moderna, que o másculo esforço da escola inglesa destacou da biologia comtista e concedeu foros de ciência distinta. Cultivada e considerada hoje condição imprescindível de toda boa instrução fundamental, eles devem ser do domínio comum e não requerem, por isso, especial e maior desenvolvimento para as aplicações que passo a fazer". ${ }^{110}$ Passando portanto dos franceses aos ingleses, Nina inicia sua defesa do método comparativo, como bem exigia sua versão do positivismo: "Aplicado à gênese das idéias do bem e do mal, do justo e do injusto, do direito e do dever - base da moral e suposto fundamento do direito de punir na escola criminalista clássica -, o método comparativo, que vimos operar tão grande revolução na psicologia, demonstra que, longe de uma procedência sobrenatural ou supra-sensível, essas idéias não são mais

109 Conforme Sevcenko, fica patente que o papel decisivo reservado à expressão "moderno"(ou seu correlato, o "novo") no jogo político. A condição agrária, retrógrada e subalterna do país no contexto internacional, agravada pelas discrepâncias sociais, era particularmente vulnerável à mística semântica de expressões como "moderno" e "novo". Contudo, a palavra "moderno" também poderia adquirir eventualmente conotação negativa, significando perda do controle, indisciplina e promiscuidade. Conforme SEVCENKO, Nicolau. Orfeu extático da metrópole, 2000, p.230-231.

${ }^{110}$ RODRIGUES, Nina. As raças humanas e a responsabilidade penal no Brasil, 1938, p.50-51. 
do que o resultado ideal da elaboração psíquica por que passou o sentimento instintivo de defesa fatal e mesmo inconsciente nas suas manifestações reflexas primordiais". ${ }^{111}$

Nina formulava assim sua crítica às legislações penais em vigor, segundo ele presas à metafísica (território da "psicologia antiga") que impedia que as funções intelectuais e morais fossem pensadas no campo da positividade científica: "Todavia, nos domínios das legislações penais reinam ainda como princípio soberano os velhos conceitos metafísicos da filosofia espiritualista". ${ }^{112}$ Nina falava da velha doutrina na qual havia uniformidade das idéias de bem e mal, do justo e injusto em todos os cérebros, "quaisquer que sejam o país e a raça". Ao citar o Ribot (1839-1916) de Maladies de la volonté ${ }^{113}$, publicado em 1884, Nina argumenta que no indivíduo, a coordenação automática precede a coordenação nascida dos desejos e das paixões, que, por sua vez, precede a coordenação voluntária, cujas formas mais simples precedem as mais complexas. A partir dessa concepção hierárquica do funcionamento psíquico, Nina Rodrigues retoma também argumentos de Spencer (1820-1903) para ressaltar que "da lei universal, que em igualdade de circunstâncias, a coesão dos estados psíquicos é proporcional à frequência com que eles se seguiram um ao outro na experiência, resulta o corolário

\footnotetext{
${ }^{111}$ RODRIGUES, Nina. As raças humanas e a responsabilidade penal no Brasil, 1938, p.51-52.

${ }^{112}$ RODRIGUES, Nina. As raças humanas e a responsabilidade penal no Brasil, 1938, p.54.

${ }^{113} \mathrm{O}$ francês Théodule Ribot, filósofo de formação, orientou-se progressivamente para a psicologia com o projeto de torná-la uma disciplina independente. Sua "psicologia objetiva" critica o que chamava de "psicologia antiga"(ancienne) associada à moral e à metafísica. Foi também o tradutor de Princípios de psicologia de Spencer para o francês, cuja obra exerceu influência incondicional em seus estudos. Conforme BRAUNSTEIN, JF. e PEWZNER, Évelyne. Histoire de la psychologie, 1999, p.92.
} 
inevitável - que toda e qualquer ação deve ser determinada por essas conexões psíquicas que a experiência gerou, seja na vida do indivíduo, seja nessa vida geral anterior cujos resultados acumulados se tem organizado em sua constituição". ${ }^{114} \mathrm{E}$ conclui que "a cada fase da evolução social de um povo, e ainda melhor, a cada fase da evolução da humanidade, se se comparam raças antropologicamente distintas, corresponde uma criminalidade própria, em harmonia e de acordo com o grau do seu desenvolvimento intelectual e moral”. Essa subordinação da criminalidade às leis da evolução geraria, portanto, uma "impossibilidade material, orgânica, a que os representantes das fases inferiores da evolução social passem bruscamente em uma só geração, sem transição lenta e gradual, ao grau de cultura mental e social das fases superiores".

Em capítulo específico da obra Os africanos no Brasil, Nina Rodrigues trata do que chamava "a sobrevivência psíquica na criminalidade dos negros no Brasil". ${ }^{115} \mathrm{O}$ atavismo era entendido como um fenômeno orgânico, do domínio da acumulação hereditária, que pressupunha uma descontinuidade na transmissão pela herança, de certas qualidades dos antepassados, saltando uma ou algumas gerações. A sobrevivência, por outro lado, era um fenômeno do domínio social, e se distinguia do atavismo pela continuidade; representaria os resquícios de temperamentos ou qualidades morais, que se acham ou se devem supor em via de extinção gradual, mas que continuam a viver ao lado, ou associados aos novos hábitos, às novas aquisições morais ou intelectuais. Nina Rodrigues considerava a reversão atávica uma modalidade de degeneração psíquica, de anormalidade ${ }^{114}$ RODRIGUES, Nina. As raças humanas e a responsabilidade penal no Brasil, 1938, p.70.

${ }^{115}$ RODRIGUES, Nina. Os africanos no Brasil, [1905]s/d. 
orgânica que, quando corporizada na inadaptação do indivíduo à ordem social adotada pela geração a que ele pertence constitui a criminalidade normal ou ordinária. A sobrevivência criminal seria, ao contrário, um caso especial de criminalidade, aquele que se poderia chamar de criminalidade étnica, resultante da coexistência, numa mesma sociedade, de povos ou raças em fases diversas de evolução moral e jurídica, de sorte que aquilo que ainda não é imoral nem antijurídico para alguns réus já deve sê-lo para outros. ${ }^{116}$

As diferenças entre os homens seriam então corroboradas pela "nova psicologia": "perante as conclusões tanto da sociologia como da psicologia moderna, o postulado da vontade livre como base da responsabilidade penal só se pode discutir sem flagrante absurdo, quando for aplicável a uma agremiação social muito homogênea, chegada a um mesmo grau de cultura mental média", ${ }^{117}$ na qual a impulsividade e a precocidade pudessem ser consideradas em um mesma intensidade biológica.

Nina critica Tobias Barreto também por este propor "uma doutrina conciliatória do determinismo com o livre arbítrio", consagrada na legislação penal alemã. Ao contrário, a escola criminalista positivista de Ferri e Garofalo (a quem Nina Rodrigues dedica o livro), seria a aplicação verdadeira da teoria evolucionista ao direito e não a leitura haeckeliana que Tobias fazia da criminalidade. Segundo Nina, Tobias "constituiu-se adversário intransigente daqueles que tendem a

116 Este pessimismo da ciência teve também penetração nos teóricos que tratavam da questão indígena no Brasil. Pressupostos raciais tiveram que dialogar com um contradiscurso que via no índio não apenas a raiz da nacionalidade, como também um caminho para o futuro da civilização brasileira. Conforme MONTEIRO, J. M. "As raças indígenas no pensamento brasileiro do Império", 1996.

${ }^{117}$ RODRIGUES, Nina. As raças humanas e a responsabilidade penal no Brasil,1938, p.71. 
identificar o crime com a loucura, os patólogos do crime na sua frase, e lançou-se em formal contradição, admitindo um livre arbítrio relativo, parcial”. Tobias teria caído aí em um erro fundamental: "quebrar o elo que prende e subordina as leis psicológicas às da fisiologia". ${ }^{118}$

Para a escola de Nina Rodrigues, a escolha dos motivos, bem como a determinação no sentido da maior resistência, o nadar contra as correntes (de que Tobias Barreto falava, ao defender o livre-arbítrio), não poderiam ser considerados manifestações da liberdade, mas tão somente a resultante da organização psicofisiológica do indivíduo: "Para produzir um grande esforço moral ou intelectual é preciso, do mesmo modo, que os centros nervosos adaptados a esse fim (quaisquer que eles sejam, e a nossa ignorância a este respeito é quase completa) estejam em condições de produzir um trabalho intenso e repetido, ao invés de se esgotar rapida e definitivamente. A possibilidade de esforço é, pois, em última análise, um dom natural. Convém explicarmos que esta maior resistência é representada pelas tendências inferiores da organização psico-fisiológica, em luta com as tendências superiores, de adaptação mais complexa, porém menos fortes por serem mais recentes". ${ }^{119}$ Nina reafirma aqui o princípio da modificabilidade defendido por Comte: "a modificabilidade se regula segundo a maior ou menor complexidade e generalidade dos fenômenos naturais. Segundo este preceito epistemológico

\footnotetext{
${ }^{118}$ RODRIGUES, Nina. As raças humanas e a responsabilidade penal no Brasil,1938, p.76-77.

${ }^{119}$ RODRIGUES, Nina. As raças humanas e a responsabilidade penal no Brasil,1938, p.85.
} 
positivista, os fenômenos mais simples e gerais seriam também os menos modificáveis". ${ }^{120}$

Sendo assim, o ato impulsivo não é, como afirmava Tobias Barreto, um ato sem motivos, "pois na motivação psíquica, além dos motivos externos, objetivos, aparentes, os fins da ação, há ainda os motivos internos, organizados, hereditários, ou adquiridos, e inconscientes ou subconscientes. Variando desde o automatismo reflexo até a impotência voluntária consciente, os atos impulsivos depõem, ao contrário, contra a existência da vontade livre. O estudo da desorganização do ato volitivo nas impulsões irresistíveis é muito instrutivo. Deixa ela a descoberto o mecanismo psicológico da determinação voluntária e permite verificar a sua subordinação às leis gerais da motivação". ${ }^{121}$ A impulsividade deveria ser portanto entendida como a reação ancestral que impediria o livre-arbítrio; a precocidade do crime, por sua vez, seria resultado dos diferentes ritmos de evolução aos quais estariam todos submetidos.

Como escreve Nina, em Tobias Barreto - seguidor da escola alemã - o livre arbítrio é expulso pela porta da vontade para entrar pela janela da inteligência (aqui referendo-se à “cultura espiritual"). Segundo ele, os criminalistas clássicos debatem-se com o seguinte dilema: ou punir sacrificando o princípio do livre arbítrio, ou respeitar esse princípio, em detrimento da segurança social: "Desde que os alienistas, peritos natos na matéria, se educam todos no espírito positivo e determinista da psicologia moderna, desde que por sua vez esta demonstra e prega a subordinação fatal de toda determinação, suposta voluntária, a conexões psíquicas

\footnotetext{
${ }^{120}$ BENOIT, Lelita Oliveira. Sociologia comteana: gênese e devir, 1999, p.320.

${ }^{121}$ RODRIGUES, Nina. As raças humanas e a responsabilidade penal no Brasil,1938, p.92.
} 
anteriores, era necessária a conclusão de que, quanto mais profunda e competente for a análise psicológica do criminoso, quanto mais adiantados e aperfeiçoados estiverem os conhecimentos da psicologia mórbida, tanto mais fácil será descobrir móveis de ação, inteiramente alheios à influência da vontade livre e por conseguinte tanto mais numerosas serão as declarações de irresponsabilidade e mais frequentes as absolvições" ${ }^{122}$ Marcas dessas análises estão na legislação aprovada em 1903 e regulada no ano seguinte, que estabeleceu a assistência a alienados nos Estados, proibindo a internação de alienados em cadeias públicas ou entre criminosos. ${ }^{123}$

O espírito positivo também guiava o trabalho de Franco da Rocha, diretor do Hospício de S. Paulo desde 1898. Para ele, a escola positiva do direito penal, a única de base científica, baniu a responsabilidade individual para só atender à responsabilidade social: "o guia do magistrado deve ser a temibilidade do delinquente, não a quantidade dosada, ou pesada, ou medida (não sabemos por que processo) de força de vontade que por ventura existe no criminoso durante o ato", escreve ele, enterrando qualquer referência ao livre-arbítrio. ${ }^{124} \mathrm{O}$ médico alertava para a falta de um asilo especial de criminosos, fato que forçava a reclusão nos hospícios de tratamento, de uma "chusma de degenerados que conservam a aparência e a forma normal do raciocínio, tendentes ao crime e à maldade, à fuga, cheios de vícios habitualmente incuráveis, porque é um vício congênito do cérebro e que, entretanto, perturbam completamente a disciplina e a calma necessárias num asilo, que pode ser de grande recurso para os doentes aproveitáveis", alertava

\footnotetext{
${ }^{122}$ RODRIGUES, Nina. As raças humanas e a responsabilidade penal no Brasil,1938, p.95-96.

${ }^{123}$ RODRIGUES, Nina. "Legislação sobre assistência a alienados”, 1906.

${ }^{124}$ ROCHA, Franco da. Estatística e Apontamentos, 1898.
} 
Franco da Rocha, para quem entre o grupo de degenerados, devia-se dedicar especial atenção aos desclassificados "que não cabem nem na sociedade nem no hospício" e "vivem em luta constante com a polícia".

Segundo Franco da Rocha, quase sempre o tipo mostra desde a infância a tara que vai acompanhá-lo durante toda a vida. No colégio ou na escola é um insubordinado, às vezes expulso, intolerável e incorrigível: "Se consegue fazer os preparatórios, o que é raro, fica nos primeiros degraus do curso superior, arranjando uma incompatibilidade qualquer. Vai para a Escola Militar; lá continua o mesmo homem; torna-se notável por sua inferioridade moral”, explica o médico. ${ }^{125}$

Para Franco da Rocha, a permanência no hospício deveria estar associada à utilidade do trabalho dos alienados. A ociosidade, se era uma desgraça para os espíritos sãos, deveria ser combatida especialmente para o interno adolescente. Desde que iniciara suas estatísticas em 1896, até 1911, Franco da Rocha não incluía em seus imensos quadros uma coluna para faixa etária, apesar desta referência à importância do trabalho no tratamento dos adolescentes, para quem o trabalho deveria substituir as idéias mórbidas. No trabalho do hospício seria também reproduzida a divisão de classes: a cozinha e a lavanderia eram considerados lugares ideais de trabalho para doentes de classe inferior. O trabalho físico no tratamento de moléstias nervosas mostrava-se útil por tornar o organismo mais rico em substâncias nutritivas e portanto proporcionando uma melhor nutrição do sistema nervoso central, como consequência disso seria quase normal a função dos elementos nervosos. Do ponto de vista higiênico, o trabalho era considerado um

${ }^{125}$ ROCHA, Franco da. Estatistica e Apontamentos, 1901. 
meio de desenvolvimento e moralisador, além de equilibrar as funções do cérebro. ${ }^{126}$

Esses desclassificados seriam um elemento fundamental para a análise da psicologia das massas populares, no dizer de Franco da Rocha. Candidatos constantes ao hospício, apesar da desordem do caráter demonstram fulgor da inteligência. São vencidos na luta pela existência; só são vencedores no tempo de agitação. Essa degeneração psíquica, portanto, demonstra que não há linha divisória entre predisposição e degeneração, e que torna-se impossível uma ação profilática além da esterilização, com o fim de evitar a propagação da má espécie. Psicologia das massas populares é a tradução que Franco da Rocha faz da obra do médico Gustave Le Bon, Psychologie des foules (Psicologia das multidões) ${ }^{127}$, publicado na França em 1895 e traduzido para várias línguas durante décadas. Segundo Le Bon, a ação inconsciente das multidões, substituindo a atividade consciente dos indivíduos, era uma característica da época. A "alma" de um povo seria o conjunto de caracteres comuns que o meio e a hereditariedade imprimem a todos os indivíduos de um povo. Esses caracteres seriam de origem ancestral, e por isso muito estáveis conforme o princípio de modificabilidade comteano também explicitado em Nina Rodrigues. Le Bon adverte, no entanto, que - por diversas razões - quando um número de homens se agrupa momentaneamente, vem juntar-se aos caracteres

\footnotetext{
${ }^{126}$ Conforme ROCHA, Franco da. Estatísticas e Apontamentos, 1900.

${ }^{127}$ A idéia de uma dimensão propriamente social ou cultural na psicologia já se encontra no projeto alemão de Völkerpsychologie desenvolvido por Wundt, mas cujas características também são encontradas em certos discípulos de Herbart que fundaram em 1859 a Zeitschrift für Völkerpsychologie und Sprachwissenschaft. Conforme BRAUNSTEIN, J-F. e PEWZNER, Évelyne. Histoire de la psychologie, 1999, p.161.
} 
ancestrais uma série de novos caracteres, por vezes diferentes daqueles recebidos pela raça, constituindo uma alma coletiva poderosa, mas momentânea.

O estudo da psicologia das multidões deveria ser feito, portanto, não por mera curiosidade, mas pelo interesse em descobrir as motivações das ações dos homens, e segundo o paradigma biológico dominante teria o mesmo valor que estudar um mineral ou uma planta. Segundo Le Bon, os poucos autores que se ocuparam da psicologia das multidões até então fizeram-no apenas do ponto de vista da criminalidade, como Gabriel Tarde, a cujas idéias sobre moralidade e criminalidade Le Bon se oporia radicalmente. Nas multidões de Le Bon, sentimentos precedem a inteligência, assim como em Nina Rodrigues o senso moral precede a inteligência. Para ele, o exagero das multidões incidiria unicamente nos sentimentos e de modo algum na inteligência. Em sua obra, procura demonstrar que pelo simples fato de estar inserido na multidão o nível intelectual do indivíduo reduz-se consideravelmente. A linguagem biológica exerce aqui um poder de explicação sobre o fenômeno social da multidão, como se a multidão psicológica fosse um ser provisório, composto de elementos heterogêneos que, por momentos, se uniriam, tal como as células que se unem em um corpo novo e formam um ser que manifesta caracteres bem diferentes daqueles que cada uma das células possui. Contrariamente a Spencer, no agregado que constitui uma multidão, para Le Bon não se encontra de modo algum uma soma ou média de seus elementos, mas sim uma combinação de caracteres novos tal como na química, quando certos elementos, em presença de outros, combinam-se para formar um corpo dotado de 
propriedades diferentes da dos corpos que entraram em sua composição. ${ }^{128} \mathrm{O}$ indivíduo em multidão difere do indivíduo isolado, e difere também do indivíduo da raça, cujas qualidades gerais do caráter regidas pelo inconsciente são possuídas quase no mesmo grau pela maioria dos indivíduos normais.

$\mathrm{O}$ argumento de Le Bon indicava que as "idéias democráticas estão em profundo desacordo com os dados da psicologia e da experiência”. Segundo eles, vários filósofos - como Spencer - já haviam demonstrado que a instrução não torna o homem nem mais moral nem mais feliz, que não modifica seus instintos e paixões hereditárias, e pode, quando mal dirigida, tornar-se mais prejudicial do que útil. Pesquisas da época afirmavam que a criminalidade aumentava conforme a generalização da instrução, e que os piores inimigos da sociedade, os anarquistas, eram quase sempre recrutados entre os diplomados das escolas. Dados citados por Le Bon afirmavam que havia três mil criminosos letrados para mil letrados, e que em cinquenta anos a criminalidade teria aumentado em $133 \%$, principalmente entre os jovens, para quem a escola gratuita e obrigatória substituiu o patronato. Em outras obras Le Bon já havia alertado para os descaminhos da educação, que transformavam aqueles que a recebiam em inimigos da sociedade e recrutava muitos discípulos para as "piores formas de socialismo".

A impulsividade como característica das multidões é muito mais resultado da ação da medula espinhal do que do cérebro, o que explica o fato de ela ser guiada quase exclusivamente pelo inconsciente. Como o cérebro não dirige as ações, o indivíduo procede segundo o acaso das excitações. A multidão é escrava dos

${ }^{128}$ Conforme Le Bon, G. Psychologie des foules, no capítulo "Caractéristiques générales des foules", 1895. 
impulsos recebidos, não apresenta a capacidade fisiológica do indivíduo que pode dominar seus reflexos. Essa impulsividade das multidões se dá sob intervenção dos caracteres fundamentais da raça, que constituem o terreno imutável em que germinam os sentimentos. Sendo assim, as multidões apresentam graus diferentes de impulsividade conforme sua origem racial.

\section{Impulsividade e fraqueza biológica da inteligência}

Segundo François Jacob ${ }^{129}$, o mecanicismo não teria sido transplantado para as ciências da vida, mas sim constituía a episteme ou o quadro teórico desde o século XVII, a partir de Descartes. Já para o Curso de Filosofia Positiva, uma teoria do eu absolutamente positiva teria seu fundamento teórico nas categorias biológicas. Para além de toda metafísica cartesiana, a história da nova teoria seria paralela à da criação da moderna biologia. ${ }^{130}$ Dada a especificidade dos fenômenos vitais, o método comparativo deveria ser, por excelência, aplicado no campo da biologia, por ser o mais adequado para o estudo de um objeto - a vida - que não poderia ser apreendido exclusivamente através de processos de experimentação ou da pura observação. A comparação, contudo só seria realizável caso fosse revelada certa homogeneidade dos fenômenos vitais, o que se deu com a descoberta de um elemento anatômico mais geral e mais simples - os tecidos vivos. Estaria aberto o caminho para uma fisiologia realmente positiva, e desta à "ciência das mais altas funções da animalidade", que seria possível a partir do estudo do tecido nervoso,

${ }^{129}$ FACOB, François. La logique du vivant. Une histoire de l'hérédité, 1970.

${ }^{130}$ Conforme BENOIT, Lelita Oliveira. Sociologia comteana. Gênese e devir, "Sob o paradigma da biologia", 1999. 
que distinguiria o animal do restante da escala viva. "O tecido nervoso, por seu lado, é a base fisiológica da 'faculdade da sensibilidade', tanto da 'interior' como da 'exterior'. As sensações exteriores se vinculam à satisfação de diversas necessidades: nutrição, reprodução etc., mas são as sensações interiores que formam o substrato físico das funções intelectuais e morais. A teoria positiva do eu, como se revela agora, se evidentemente é o abandono da psicologia eclética e da metafísica cartesiana, é ainda, em larga medida, também oposta ao sensualismo empirista que, segundo o Curso de filosofia positiva, não teria admitido a existência de uma base fisiológica das sensações, atribuindo-as a 'causas externas". ${ }^{131}$ É sob essas premisssas que os volumes do Curso tem como objetivo destruir a "psicologia ilusória, considerada última transformação da teologia. Contudo, o principal foco dos ataques de Comte diz respeito à introspecção, principal método utilizado por Wundt. $^{132}$

Os limites naturais impostos pela teoria da modificabilidade comteana são fruto, portanto, do abandono da procura das causas, fossem elas físicas ou metafísicas, e com o foco direcionado para a descoberta das leis. Como vimos, no campo da criminologia, deixa-se de questionar sobre as causas da criminalidade, e passa-se a estudar as leis que regem a "psicologia do criminoso". Tal estudo só seria possível a partir dos pesquisas realizadas pela craneologia, resultado de uma aliança

\footnotetext{
${ }^{131}$ BENOIT, Lelita Oliveira. Sociologia comteana, p. 304-305.

${ }^{132}$ Wundt faz uma distinção entre "auto-observação experimental", que é uma forma de introspecção verificável, dirigida, na qual os sujeitos são colocados em situações-padrão, repetíveis e são solicitados a responder de forma quantificável; e uma introspecção considerada por ele pré-científica, não controlável, que nomeia "percepção interna". Conforme BRAUNSTEIN, J-F. e PEWZNER, Évelyne. Histoire de la psychologie, 1999, p.88.
} 
sinistra entre evolução e quantificação. ${ }^{133}$ Para os craneologistas, uma preocupação permanente foi explicar o cérebro grande de vários criminosos, como por exemplo um cérebro feminino bastante pesado pertencente a uma mulher que teria matado o marido.

Um dos estudos de fisiologia cerebral de Paul Broca (1824-1880) - expostos por Gould - procurava demonstrar o crescimento progressivo do tamanho do cérebro concomitante ao desenvolvimento da civilização européia desde a Idade Média até a Era Moderna. Assim como o cérebro feminino havia se degenerado através do tempo por causa da utilização parcial que lhe fora imposta pelas condições sociais, as raças primitivas não acompanharam a marcha da civilização imposta aos cérebros dos europeus. ${ }^{134}$ Durante vários anos a médica e pedagoga italiana Maria Montessori (1870-1952) ensinou antropologia na Universidade de Roma e escreveu um livro de razoável repercussão intitulado Antropologia pedagógica, cuja edição inglesa é de 1913. Segundo Gould, ela apoiou as teses de Broca, bem como a teoria da criminalidade inata proposta por seu conterrâneo Lombroso. Mediu a circunferência da cabeça das crianças que frequentavam sua escola e concluiu que as mais promissoras tinham cérebros maiores.

Tanto a biologia comteana quanto as pesquisas de Broca baseavam-se em estudos do anatomista austríaco Franz Joseph Gall, fundador da frenologia, que publicou, no início do século XIX, em colaboração com J. G. Spurzheim, estudos sobre as funções do cérebro. É interessante ressaltar que Gall considerava seu

\footnotetext{
${ }^{133}$ Conforme GOULD, S.J. A falsa medida do homem, 1991.

${ }^{134}$ Le Bon é considerado por GOULD como o principal misógino da escola de Broca. Para ele, as mulheres representavam a forma mais inferior da evolução humana, mais próximas portanto das crianças e dos selvagens de que um adulto civilizado.
} 
trabalho como um ramo da filosofia, e não explicitamente médico, e baseava a frenologia em cinco princípios, entre eles a identificação definitiva do cérebro ao órgão das faculdades morais e intelectuais, enterrando a idéia presente em Cabanis de que certas faculdades psíquicas, particularmente os sentimentos, estavam alocados em órgãos da digestão. ${ }^{135}$

Na Lição 45, Comte confirma as observações da frenologia sobre a fraqueza biológica da inteligência: a porção "mais volumosa e animal do cérebro humano" se localizaria na "parte posterior, e esta seria simples prolongamento da coluna vertebral, centro primitivo do sistema nervoso". Por sua vez, a parte do cérebro mais humana é também "a mais afastada de sua origem primitiva, menos volumosa, menos enérgica". Ora, as faculdades afetivas se localizariam na porção posterior e média do cérebro; os seres humanos compartilham estas faculdades com todas as outras espécies animais, ou, nas palavras de Comte, “elas constituem a base comum de toda animalidade". As faculdades intelectuais, por sua vez, se localizariam na parte frontal do cérebro que corresponde à sua menor porção, ocupando a sexta ou quarta parte da massa encefálica. Comte concluia assim que a maior parte dos seres humanos nunca desenvolveria a parte superior-frontal do cérebro, e ficaria limitada às funções afetivas, originárias da região cerebral mais animal. ${ }^{136}$

No próximo capítulo procuramos mostrar como inteligência torna-se uma categoria psicológica fundamental - e não mais apenas biológica - na delimitação da infância criminalizada recolhida às escolas correcionais. A inteligência libera-se

\footnotetext{
${ }^{135}$ Conforme BRAUNSTEIN, J-F e PEWZNER, É. Histoire de la psychologie, p.72.

${ }^{136}$ Conforme análise realizada em BENOIT, Lelita Oliveira. Sociologia comteana, 1999, p.318.
} 
de sua "fraqueza biológica" e constitui um bloco perigoso quando associada a uma nova categoria: a perversidade. 


\section{Inteligência e perversidade no estrago da alma infantil: a psicologia classificatória na ortopedia moral}

O debate em torno da questão do discernimento, da impulsividade e da precocidade chegou ao início do século XX e subsidiou a criação de instituições públicas para correção. Esta correção não visava apenas aquelas crianças já viciadas, pervertidas, criminosas; visava também e sobretudo aquelas em perigo moral.

Tudo indica que Cândido Motta, professor de direito criminal, ${ }^{137}$ foi o primeiro a formalizar na Câmara dos Deputados projeto para criação de um instituto correcional em São Paulo, do qual seria diretor. ${ }^{138}$ Durante dois anos seu projeto foi debatido, e aprovado posteriormente com modificações e convertido em lei

\footnotetext{
${ }^{137}$ Candido Motta ocuparia vários cargos importantes no governo paulista, sendo também deputado estadual. Seria também o presidente da comissão julgadora de seleção do projeto para a Penitenciária do Estado, inaugurada oficialmente em 1920, e que substituiria a velha penitenciária da avenida Tiradentes.

${ }^{138}$ Paulo Egydio havia apresentado em 1893 um projeto no Senado para criação de um Asylo Industrial de São Paulo, voltado para o "amparo de crianças abandonadas", em que seriam recolhidas para o trabalho e a educação com o intuito de prevenir crimes futuros e fazia parte de uma rede de instituições proposta ao Senado. Quando Candido Motta apresenta seu projeto para o Instituto Disciplinar, Paulo Egydio paticipa dos debates e das reformulações pelas quais o projeto passou. Conforme SALLA, Fernando. As prisões em São Paulo, 1999, p.168. Paulo Egydio também foi o autor de um projeto de lei apresentado ao Congresso Legislativo da Província de São paulo em 1892, que previa a introdução nas escolas normais das cadeiras de "psychologia e lógica". Conforme MASSIMI, Marina. História da psicologia brasileira, 1990, p.70.
} 
regulamentada por decreto em dezembro de 1902. Entre as modificações propostas, estava a alteração no próprio nome da instituição, que passou de Instituto Educacional Paulista a Instituto Disciplinar. ${ }^{139}$

Ficava então o governo do Estado autorizado a fundar, onde julgasse mais conveniente, um Instituto Disciplinar e uma Colônia Correcional, destinada à "correção, pelo trabalho, dos vadios e vagabundos, como tais condenados", com idades entre 14 e 21 anos. Em 1906, segundo Relatório da Secretaria da Justiça e Segurança Pública, foram presas 1500 crianças pela polícia da Capital, sendo 119 por gatunagem, 182 por embriaguez, 199 por vagabundagem, 458 por desordens e 486 por outros motivos considerados de menor gravidade. ${ }^{140}$ As atividades de recolhimento das crianças-menores continuavam a ser realizadas pelo corpo policial da cidade. ${ }^{141}$

Primeira escola correcional a ser implantada, a Escola Premonitória 15 de Novembro, ${ }^{142}$ na cidade do Rio de Janeiro, definia em seu segundo estatuto (1910) que tinha por finalidade 'ministrar educação física, profissional e moral aos menores abandonados e recolhidos ao estabelecimento, por ordem das autoridades competentes'. ${ }^{143}$ Eram considerados abandonados 'os menores de 14 anos, maiores de nove que, por serem órfãos, ou por negligência, ou vícios, ou enfermidades, ou

\footnotetext{
${ }^{139}$ Entre as outras modificações estava o impedimento da internação dos filhos de presidiários e dos menores entre nove e 14 anos completos que tivessem agido sem discernimento, além de alterações na divisão interna do Instituto, que veremos mais adiante.

${ }^{140}$ Sobre as crianças pobres na Primeira República ver MARCILIO, Maria Luiza. História social da criança abandonada, 1998 e MOURA, Esmeralda Blanco Bolsonaro de. "Infância operária e acidente de trabalho em São Paulo". In: Priore, Mary del (org.) História da criança no Brasi, 1995, pp.112-128.

${ }^{141}$ Sobre polícia e menoridade na cidade do Rio de Janeiro, ver VIANNA, Adriana de Resende, O mal que se adivinha, 1999.

142 A Escola existia desde 1899, em caráter particular, sob a direção de um cônego, e foi incorporada pelo Estado em 1903. Não poderia ser mais significativo o novo nome escolhido pelo Presidente.

${ }^{143}$ As criança consideradas "delinquentes ou viciosas" seriam enviadas para a Colônia Correcional de Dois Rios, criada no mesmo período. Conforme ASSIS, Márcio Branco de. A criança e a ordem, 1997.
} 
falta de recursos dos pais, tutores, parentes ou pessoas em cujo poder, guarda ou companhia viviam, ou por outras causas, forem entregues às autoridades judiciárias ou policiais, ou forem encontrados habitualmente sós na via pública, entregues a si mesmos e desamparados de qualquer assistência natural"'. ${ }^{144}$ Seguindo o modelo da capital, em 1909 foi criado em Minas Gerais o Instituto João Pinheiro, distante do centro da capital mineira. ${ }^{145}$

No bairro paulistano do Tatuapé, em 1902, instalou-se a colônia premonitória e disciplinar, proposta por Cândido Motta: ${ }^{146}$ o Instituto Modelo ou Instituto Disciplinar. Uma escola "premonitória" significava uma instituição que "adverte", ou "que adverte com antecipação", que se deve tomar como aviso; tinha, portanto, como alvo as crianças em perigo moral. Segundo o jurista, era preciso aguçada "intuição psicológica" para detectar o grau de degenerescência de cada uma das crianças em perigo moral, ou o que ele mesmo chamava de "estrago da alma". O tratamento dispensado às crianças deveria levar em conta principalmente "a hereditariedade psíquica determinante do caráter de cada um”. O caráter, por sua vez, mereceria um estudo sistemático e acurado, baseado na nova ciência chamada "ortopedia moral" - uma espécie de ramo da medicina mental especializado em canalizar para o bem tendências e paixões indesejadas. Para os casos em que tivessem fracassado todos os meios para regenerar uma criança "viciosa e impulsiva", o autor sugeria experimentar o sono hipnótico, quando os conselhos se

\footnotetext{
${ }^{144}$ MARCILIO, Maria Luiza. História social da criança abandonada, p.216.

${ }^{145}$ A Escola 15 de Novembro seria oficialmente "extinta" com a criação do SAM (Serviço de Assistência a Menores), em 1941. Ver PASSETTI, Edson. "Crianças carentes e políticas públicas", 1999, p.362.

${ }^{146}$ MOTTA, Candido Nogueira da. Os menores delinquentes e o seu tratamento no Estado de São Paulo, 1909.
} 
transformariam em ordens. ${ }^{147} \mathrm{O}$ tratamento moral deveria ser colocado em prática por meio de um sistema de recompensas e punições a partir de um dossiê médicopedagógico individual. Por tratamento moral entendia-se o efeito direto de uma mente sobre outra, fosse de natureza calmante ou por medidas repressivas adotadas diante de tendências viciosas ou perigosas. Em outras palavras, o "ambiente psíquico é modificado no sentido de induzir a resposta saudável e encorajar a adaptação normal". ${ }^{148}$

O sistema do projeto proposto por Candido Motta tinha por base uma classificação das crianças em três tipos, o que deveria permitir a internação em pavilhões isolados: os duvidosos (classe de observação, mas que abrangeria os pequenos criminosos que agiram sem discernimento, que desapareceria no projeto aprovado); os maus (crianças criminosas que agiram com discernimento); e os bons (aqueles apenas em perigo moral), restando a possibilidade de criar subclassses segundo a idade, em pavilhões distintos ou não, mas sem comunicação entre si. Na formulação original do projeto, o Instituto deveria recolher, além dos menores de 21 anos vagabundos, criminosos, também aqueles com idade superior a 9 e inferior a 14 que tivessem agido sem discernimento. Depois de sofrer alterações, por meio de pareceres e substitutivos, este tópico seria retirado e para o Instituto ficava prevista a internação de menores naquela mesma faixa etária de 9 a 14 anos, porém apenas aqueles que tivessem atuado com discernimento. Continuava-se a recolher também vadios, abandonados e pequenos criminosos acima de 14 anos. ${ }^{149}$

\footnotetext{
${ }^{147}$ Como já dissemos, a hipnose já gozava de reconhecimento médico desde o final do século.

${ }^{148}$ Conforne LEWS, W. B. "The treatment of insanity”, 1899.

${ }^{149}$ Conforme SALLA, Fernando. As prisões em São Paulo, 1999, p.169.
} 
Seguindo as premissas do discurso jurídico hegemônico, o projeto entendia que crime, loucura, alcoolismo e "nervosismo" eram anéis de uma mesma cadeia. A influência da hereditariedade psíquica ou moral pesava sobre a criança, e deveria ser combatida pela influência modificadora da educação, entendida como um "tratamento psicofísico" 150 apropriado, dependendo principalmente do "grau de inteligência e perversidade" constatada. A precocidade da criminalidade também provocava armadilhas, já que a classificação etária poderia ser enganosa. Era preciso classificar as crianças, mas não sob o ponto de vista legal, porque corria-se o risco de "ver um mendigo mais degenerado que tal assassino". Era preciso classificar do ponto de vista "antropopsicológico", ou seja, "classificar segundo o grau de degenerescência". A direção de tais estabelecimentos deveria estar nas mãos de um médico e um pedagogo que deveria ter "muita intuição psicológica" para fazer o diagnóstico do mal e indicar o remédio adequado aos espíritos enfermos. Pedagogo e médico se completariam na criação da nova ciência, chamada ortopedia moral. O médico, nesses casos, supriria a necessária competência que faltaria aos juízes, incapazes de fazer um estudo acurado de cada criança.

Para o bom andamento do novo modelo institucional, era preciso distinguir claramente entre defeitos da inteligência e desequilíbrio mental, conforme já alertava Franco da Rocha ${ }^{151}$, pois o desequilibrado superior poderia apresentar uma inteligência sublime. Sob essa lógica, seria justamente a inteligência o elemento a

\footnotetext{
${ }^{150}$ A "lei psicofísica" foi elaborada por Gustav Fechner (1801-1887) a partir do "paralelismo psicofísico" estabelecido na filosofia. É para aprofundar a questão da alma e do corpo que ele funda a psicofísica, definida como a ciência exata dos estudos de dependência funcional existente entre os corpos e a alma, mais genericamente, entre os mundos material e mental, físico e psicológico. A publicação de Elementos de Psicofisica em 1860 não se refere apenas à história da psicologia experimental; Freud se interessará particularmente por sua obra, referindo-se a ele como "o grande Fechner". Conforme BRAUNSTEIN, JF. e PEWZNER, Évelyne. Histoire de la psychologie, 1999, p.78.

${ }^{151}$ ROCHA, Franco da. Fragmentos de Psychiatria, 1895.
} 
distinguir os diferentes grupos de degenerados. A inteligência seria nula no idiota, começa a esboçar-se no imbecil, e já aparece bem mais clara no débil, tomando algumas vezes, quando chega ao superior, as proporções do sublime. Conforme essa lógica, em razão inversa a essa faculdade encontram-se os estigmas físicos: grosseiros no idiota e difíceis de se encontrar no superior.

A ortopedia moral deveria atuar principalmente por meio da manipulação e do controle de impulsos. Tal método era fundamentalmente inspirado nos trabalhos de G. Stanley Hall (1844-1924), pesquisador da psicologia que após estudos na Alemanha dedicou-se totalmente a estudos sobre a infância. Em um esforço para formular o que seria "natural" em cada estágio de desenvolvimento, por volta de 1900 ele aplicou os mesmos métodos a jovens, e publicou um livro quatro anos depois intitulado Adolescência, defendendo a idéia de que era o período correspondente à época entre a selvageria e a civilização. Como já vimos, o argumento - baseado na teoria da recapitulação - não era inédito, mas a novidade estava na formulação de um programa de normas para o desenvolvimento da criança. Para ele, selvagens eram crianças com maturidade sexual, como adolescentes em tamanho adulto.

Cada novo estágio de desenvolvimento, na visão de Hall, começava com uma infusão maciça de novas instintos. Seis e sete anos era um período de crise, seguido por um período de oito a doze anos em que o menino era pouco imaginativo e emocional, uma réplica individualista dos primeiros pigmeus. Depois, após um novo nascimento virtual, emergia o adolescente, um produto semelhante ao 
homem antigo e medieval - imaginativo, emocional, capaz de idealismo e participação na vida em comunidade, mas não completamente moderno.

Os primeiros Handbook of Scout Masters ${ }^{152}$ (Manuais escoteiros) utilizavam essa sequência, e propunham atividades específicas para cada idade baseando-se na psicologia de Hall. Rudyard Kipling, o poeta do imperialismo inglês, empregou a nova versão da tese da recapitulação na primeira estrofe de sua mais célebre apologia da raça branca:

\author{
Toma o fardo do homem branco \\ Envia o melhor da tua prole \\ Impõe o exílio a teus filhos \\ Para servir a necessidade do cativo: \\ Para assistir, em pesada labuta, \\ A povos alvoroçados e incultos - \\ Indolentes raças que acabam de conquistar, \\ Mescla de demônio e de criança. ${ }^{153}$
}

A psicologia de Hall descreve variadas "formas psicopáticas, quase todas ligadas aos desejos sexuais bruscamente despertados pela puberdade". Segundo o autor, a instrução por si só não bastava, cuja ação seria quase nula sobre a formação

\footnotetext{
${ }^{152}$ Sobre o movimento escoteiro e os "formadores de caráter" ver MACLEOD, David. Building character in the american boy. The Boy Scouts, YMCA, and their forerunners, 1870-1920, 1983.

${ }^{153}$ No Brasil, a recepção do escotismo apropriou diferentes teorias de psicologia e, a partir desta apropriação, o escotismo foi largamente introduzido no sistema escolar público em São Paulo e no Rio de Janeiro, constituindo uma particular pedagogia do civismo. Se na Inglaterra o 80 escotismo foi organizado para lidar com o que se considerava fraqueza de crianças e jovens e para mobilizá-los frente às insurreições anti-coloniais e diante da mobilização civil instituída com a Primeira Grande Guerra, no Brasil o escotismo era incentivado pela Liga de Defesa Nacional, e sua difusão esteve estreitamente associada ao sistema escolar público, que via no movimento um "método pedagógico" que representaria uma "escola primária de civismo". Para os formuladores da necessidade de reforço da nacionalidade, robustecer o caráter de crianças e jovens seria a chave para realizar um grandioso destino pátrio. Esta concepção levaria alguns anos depois o Estado Novo a adotar o escotismo como modelo para sua Juventude Brasileira, movimento que pode ser ideologicamente associado a Balilla e a Juventude Hitlerista. CYTRYNOWICZ, R. e ZUQUIM, J. "A psicologia escoteira: teoria do caráter como pedagogia de civismo", 1999.
} 
do caráter, que dependia essencialmente de sentimentos e das emoções, estimulados pela "educação familiar e pela ambiente social". Segundo Hall, não bastava abrir escolas, sendo imprescindível organizar o ensino profissional. ${ }^{154}$

$\mathrm{Na}$ ampla classificação de "anormais" Hall incluía "as crianças que, por herança degenerativa ou por outra causa, revelam nível intelectual e moral muito abaixo do comum. A anormalidade quanto aos seus graus, ia desde a completa idiotia e a imbecilidade até a simples fraqueza da inteligência, ou do caráter, de certas crianças, tidas apenas por estúpidas, permanecendo na retaguarda de todas as classes, nada aproveitando do ensino, por melhores que sejam os esforços dos mestres". Segundo Hall, das fileiras do exército de desclassificados saíam muitos dos criminosos precoces. Assim, propunha que uma observação médico-pedagógica deveria "distinguir os colegiais normalmente vadios ou preguiçosos dos que a psicologia mórbida chama de difíceis, que constituem a classe mais numerosa dos anormais". Nessa visão, a escola seria uma faca de dois gumes: quando não constituísse um freio moral, seria uma espécie de estimulante intelectual, um "aperitivo mental".

As "crianças difíceis" [enfants difficiles] foram objeto de numerosas publicações depois que Itard e seu colaborador Séguin divulgaram seus principais estudos entre 1838 e $1846^{155}$ e são apontadas como uma espécie de capítulo a parte

\footnotetext{
${ }^{154}$ As referências a Hall aqui citadas estão na publicação HALL, G. Stanley. Aspects of child life and education, 1921. A primeira edição do texto é de 1907.

${ }^{155}$ Roubinovitch cita os seguintes publicações em língua francesa: Abadie, Albanel, Apert, Baguer, Beaunis, Beauvisage, Binet, Blin, Boncour, Boulenger, Bouneville, Charron, Chazal, Claparède, Combemale, Compayré, Courjon, Dallemagne, Damaye, Daniel, Decroly, Degand, Delporte, Delvaille, Demoor, Dubois, Duprat, Falret, Féré, de Fleury, Fouillé, Fournier, Mme. Fuster, Ganguillet, Granvilliers, Granjux, Grasset, Grenier, Jonckheere, Joly, Legrain, Ley, Mangnan, Manheimer, Maupaté, Mme. Musy, Moreau, Nyns, Pérez, Phillippe, Pornain, Raymond, Régis, Rollet, Roume, Szana, Simon, Sollier, Paul Strauss, Toulouse, Van Biervliet, Vaney, Vaschide, Félix Voisin, Jules Voisin, René Voisin, Vurpas. Em língua alemã, são citados: Ebbinghaus, Kuhlmann, Kraepelin, Lobstein, Neumann, Rodenwalt, Sommer, Stern,
} 
na extensa família das crianças mentalmente anormais. 'Crianças difíceis' era expressão que não poderia ser utilizada como sinônimo de 'crianças viciosas'. Tratava-se de crianças que apresentariam caráter insociável a tal ponto que seria necessário separá-las de seu meio familiar e escolar e submetê-las a um regime educativo especial. As crianças viciosas, por sua vez, seriam crianças difíceis já submetidas sem sucesso a diversos meios de reforma, e que portanto apresentavam defeitos constitutivos profundos. Os defeitos nas crianças difíceis apresentavam-se ainda suscetíveis de serem suprimidos por meio de uma intervenção pedagógica e psiquiátrica apropriada. Uma criança difícil passaria ao território dos viciosos apenas se se mostrasse absolutamente refratária a esta intervenção especial. Por indicação de psiquiatras como Roubinovitch, essa terminologia penetrou na legislação francesa e separou as crianças "difíceis" das "viciosas", que deveriam ser julgadas e punidas. Segundo a lei de 1904, eram chamados pupilles difficieles aqueles não capazes de se beneficiar do ambiente familiar, mas ainda não poderiam ser considerados viciosos.

Um desenvolvimento intelectual específico era marca de caráter das crianças difíceis, que poderiam ser divididas em duas grandes classes: uma primeira classe seria caracterizada por uma depressão intelectual, e uma segunda por excitação intelectual, que incluía sinais como ataques de cólera, indisciplina, roubo e onanismo. Esses sinais poderiam estar associados a uma inteligência normal ou lacunar. Em casos de inteligência normal, o que caracterizava a criança difícil era a

Trüper, Wagner, Weygandt, Ziehen. Em língua inglesa: Burk, Corter, Berthold, Christopher, Gilbert, Mac Donald, Mackenzie, Porter, Spearman, Tarbell, Warner. Em língua italiana: Ferrari, Guicciardi, Morselli, S. De Sanctis e Pizzoli, este último pesquisador chamado ao Brasil para a montagem do Laboratório de Psicologia da Escola Normal em São Paulo em 1912. Ver MASSIMI, M. História da psicologia brasileira, 1990, p.72. 
desordem de sua conduta. Saliente-se ainda que os sinais de depressão ou excitação intelectual poderiam ser observados alternativamente em uma mesma criança. Os que não se encaixavam nas descrições eram considerados como semi-difíceis, subdifíceis e falsos-difíceis.

Esta psicologia classificatória exigia, portanto, a criação de instituições que recebessem aquele grupo específico de crianças "anormais" excluídas da escolarização por uma associação perigosa entre inteligência e perversidade: os criminosos precoces, para os quais uma escola especial deveria ser capaz de corrigir o rumo e eliminar a ameaça de outro destino: aquele da nação. No Brasil, a educação das crianças classificadas como anormais de inteligência preocupava médicos, juristas e educadores, que buscavam novas teorias que fundamentassem a reorganização desse sistema paralelo destinado a reagrupar as crianças conforme um classificação precisa.

Em 1913 Basilio de Magalhães - um professor de história do Gymnasio de Campinas, membro da Academia Paulista de Letras e do Instituto Histórico de São Paulo - publicou Tratamento e educação das creanças anormaes de intelligencia. ${ }^{156}$ Com epígrafe de Roubinovitch (Alienés e anormaux, Paris, 1910), o autor reunia em livro uma série de artigos publicados na Gazeta de Notícias de julho a outubro daquele mesmo ano, demonstrando o que poderia ser considerado uma "atualização" em relação ao tema. Segundo o autor, tratava-se de propor "uma ação preservadora e defensiva que mais de perto se vincula ao orgânico evolver da nacionalidade, pois the interessa fundamentalmente à instrução, à economia, à ordem e à moralidade, as quais estão sempre na dependência das condições

${ }^{156}$ MAGALHÃES, Basilio de. Tratamento e educação das creanças anormaes de intelligencia, 1913. 
existenciais da raça, isto é, na razão direta do seu vigor físico, da sua capacidade mental e da sua cultura afetiva".

A “educação da infância ferida de anomalias cerebrais" era considerada uma preocupação do "grande Estado cafeeeiro" ao lado da "regeneração dos menores delinquentes". Preocupado com a "educação da infância acometida de degenerescência psíquica”, o autor cita que em 1900 o psiquiatra Carlos Eiras apresentou ao $4^{\mathrm{o}}$ Congresso Brasileiro de Medicina e Cirurgia realizado no Rio de Janeiro o trabalho intitulado "Da educação e tratamento medico-pedagogico dos idiotas", impresso na Revista Médica de São Paulo em 1902. Carlos Eiras participaria um ano depois da criação do Pavilhão Bourneville no Hospício Nacional, o primeiro serviço organizado de assistência a crianças combalidas de "insânias graves", entre elas a "infância acometida de perturbações da vida de relação, menores degêneres e atrasados psíquicos", cuja direção ficou a cargo do pediatra Fernandes Figueira e de Juliano Moreira. Entre os avanços na área, o autor citava Freud, apresentado como "célebre neurologista vienense, que dedicou-se ao estudo dos fenômenos sexuais e o seu papel no desenvolvimento ulterior da mentalidade infantil". ${ }^{157}$

Ao esboçar uma classificação do mal orgânico que atingia as bases da nacionalidade no país, Basílio de Magalhães criticava a substituição, na Suíça, por meio de uma reforma instituída em 1912, da expressão "crianças anormais", que despertaria a idéia de um defeito ou enfermidade permanente, pela de "crianças atrasadas", que segundo ele denotaria apenas uma demora ou paralisação do

\footnotetext{
${ }^{157}$ Quando Basílio de Magalhães escreve, Freud já teria publicado Três ensaios sobre a teoria sexual, editado pela primeira vez em 1905; Teorias sexuais infantis, em 1908; e publicaria o texto que ficou conhecido como "Caso Hans" em 1909.
} 
desenvolvimento intelectual e moral da criança. Criticava também a mudança nos termos utilizados nos Estados Unidos, onde a expressão "anormais de inteligência" passava a ser substituída por atypical children e exceptional children, em que o atraso mental constituiria exceção e não regra. Concluindo, o autor sugere que no Brasil fosse mantido o termo "anormais" para aqueles que sofrem de um mal permanente e incurável e "atrasados" para aqueles atingidos por enfermidades transitórias, formulando assim uma classificação "própria" às crianças brasileiras.

Sob a nova classificação, a "perversão dos instintos" - que levaria ao crime precoce - seria assim definida como uma das características da anormalidade de inteligência, entendida como sendo "a parada do desenvolvimento, congênita ou superveniente, das faculdades intelectuais, morais e afetivas". Citando autores como de Sanctis, Binet, Demoor e Boncour, o autor concluia que o atraso intelectual podia ou não ser uma enfermidade inata dos centros nervosos, provocando transtornos no desenvolvimento mental e impossibilitando os indivíduos por ela acometidos de se adaptarem ao meio em que vivem. Ou seja, há uma impossibilidade de tais crianças aprenderem as regras do social como consequência de uma anormalidade da inteligência.

Basílio de Magalhães deu uma série de conferências em 1915 em que ficou patente a revisão do conceito de raça (explicitado no capítulo anterior) diante do temor provocado por uma "nacionalidade fraca" ${ }^{158}$, colocada em questão a partir da eclosão da Primeira Guerra. Passa-se a uma defesa do elemento nativo brasileiro,

\footnotetext{
${ }^{158}$ Poucos anos depois, os anseios paulistas em assumir o controle econômico, político e até mesmo militar dos destinos da República levaria seus dirigentes não apenas a visar o inimigo externo, mas também o interno na forma maciça de contingentes imigrantes e massa de proletários. Conforme SEVCENKO, Nicolau. Orfeu extático da metrópole, 2000, p.138-139.
} 
criticando-se os "exageros" de Gobineau e Agassiz. Em suas conferências, Basílio rejeita raça e clima nas explicações para o fato do Brasil ser "o grande doente da América do Sul". Refutava o arianismo, advogando em favor das realizações históricas dos mestiços. Para ele, o Brasil "passava pela crise da puberdade, enquanto a Europa entrava na menopausa". Basilio de Magalhães apontava para aspectos positivos da guerra, que sinalizava a possibilidade de o Brasil "fixar definitivamente sua personalidade no concerto americano e universal".

O futuro da nação dependia de uma educação nos trilhos do progresso, cujo poder de modificabilidade seria estendido também aos "anormais de inteligência". Cumpria fortalecer física e moralmente a raça por uma bem orientada e sistemática educação, tanto sensorial quanto cívica: "Todo o nosso futuro depende de amalgamarmos sabiamente os nossos heterogêneos elementos étnicos, desenvolvendo-lhes em tipos fixos e fortes, por meio da educação, as boas qualidades, e suprimindo-lhes quando for possível, os defeitos e os vícios originários".

\section{Espirito-intelecto-inteligência}

A conexão entre defeitos da inteligência e inadaptação ao meio estava presente já em 1855, quando Herbert Spencer publicou Princípios de Psicologia, quatro anos antes de Origem das espécies de Darwin. Naquele momento, Spencer não apenas anunciava a visão da psicologia como uma ciência biológica, mas

\footnotetext{
${ }^{159}$ Conforme análise de SKIDMORE, T. E. Preto no branco. Raça e nacionalidade no pensamento brasileiro, 1989, p.184-185.
} 
fundamentalmente apresentava a categoria "inteligência" como um conceito central para tal ciência. ${ }^{160} \mathrm{Na}$ língua portuguesa, ainda poucos anos antes um dicionarista elaborava sua remissiva da seguinte forma: inteligência. Ver espírito. O espírito "pensa, raciocina, compreende, reflete, abstrai, julga e inventa o que se pode imaginar". Já a inteligência “é hábil, e penetrante. Apodera-se das coisas abstratas e difíceis; faz os homens próprios aos diversos empregos da sociedade civil, que se enunciem com termos corretos, e com que executem regularmente". No campo das oposições, a "tolice é oposta ao espírito, a loucura à razão, o disparate ao bom senso, o estouvamento ao juízo, a imbecilidade ao entendimento, a estupidez à concepção, a incapacidade à inteligência, e a inépcia ao gênio". ${ }^{161}$ Voltando ainda um pouco mais na construção da língua portuguesa, inteligência é definida como "essência espiritual", e como exemplo o dicionarista escreve: "os anjos são pura inteligência”. Nessa mesma obra de 1813, inteligência também aparece como sinônimo de "discernimento". ${ }^{162}$

$\mathrm{Na}$ filosofia evolucionista de Spencer inteligência reemerge com um significado teórico específico: um processo básico em que quanto maior a adaptação, maior o nível de inteligência, conforme uma lei da evolução formulada como um princípio da mecânica. ${ }^{163}$ Dispara-se assim uma classificação em que o

\footnotetext{
160 Ver análise realizada por DANZIGER, Kurt. Naming the mind, 1997, capítulo específico sobre "inteligência"intitulado "Putting intelligence on the Map".

161 Conforme a publicação de 1842 Diccionario da maior parte dos termos homonymos e equivocos da lingua portugueza, verbetes 'inteligência' e 'espírito'.

162 Conforme Diccionario da Lingua Portugueza, compilado pelo carioca Antonio Moraes Silva, segunda edição de 1813. Neste dicionário de dois volumes não há os verbetes "psicologia" e "biologia"; e "evolução" é definida como sendo "o movimento que se mandam fazer os batalhões".

163 “A evolução é um processo de integração de matéria com dissipação concomitante de movimento, processo no curso do qual a matéria passa de um estado de homogeneidade relativamente indefinida e incoerente para um estado de heterogeneidade relativamente definida e coerente e no curso do qual o movimento conservado sofre uma transformação paralela". Spencer citado em DUCHESNEAU, François. “A filosofia anglo-saxônica de Bentham a William James”, 1983, p.125.
} 
ponto de partida do argumento estava numa adaptação marcada por graus. Quanto melhor a adaptação, mais alto o grau de inteligência, associando-se assim a lei da evolução à lei do progresso. O corte efetuado por Spencer se refere a considerar que os humanos tem inteligência por seu status como seres biológicos, e não como seres espirituais. A imagem de um mundo como uma arena em que seres vivos estão sendo constantemente testados baseava-se nas convicções vitorianas compartilhadas por Darwin e Galton.

Esta inteligência spenceriana era radicalmente diferente das "faculdades intelectuais" como objeto de estudo da psicologia, conforme indica definição em língua portuguesa no início do século. Em 1905, Psychologia era entrada de dicionários com a seguinte descrição: "Estudo da alma e suas manifestações, isto é, das faculdades intelectuais e morais" ${ }^{164}$ Psicologia como estudo da alma, ainda não uma ciência, mas tendo em vista uma alma construída sob intelecto e moralidade. Um estudo específico, uma vez que, segundo o mesmo dicionário, psychologismo seria o "conjunto das theorias psychologicas". Nas definições desse período, evidencia-se ainda uma divisão curiosa: por um lado há o psychologo, "indivíduo versado em psychologia', mas há também o psychologista, "indivíduo que se ocupa da psychologia".

Os primeiros artigos de Binet relativos à medida de inteligência aparecem em 1905, e dois anos mais tarde a escala métrica de inteligência já encontra uma aplicação prática. A invenção da escala se inscreve explicitamente em um projeto pedagógico dirigido por Binet, para estabelecer com precisão o diagnóstico de

\footnotetext{
${ }^{164}$ Conforme verbete 'psychologia' em Diccionario da lingua portugueza de Fernandos Mendes, publicado em 1905.
} 
debilidade a fim de evitar que aqueles alunos com defeitos de inteligência ingressassem nas classes regulares. Este projeto pedagógico, formalizado na redação de um Guide pour l'admission des enfants anormaux dans les classes de prefectionnement, encontra sua formalização por meio de uma lei em 1909, que pretendeu instituir sob certas condições a generalização de classes especiais na França ${ }^{165}$ Há portanto uma relação direta entre a invenção da escala e a implantação de políticas públicas para a infância anormal, para a qual fora criada uma comissão interministerial com a participação ativa de Binet.

Binet questionava a classificação médica dos idiotas, que ordenava os quadros clínicos conforme incapacidades motoras ou mal-formações. Para ele, as crianças anormais deveriam ser classificadas apenas conforme seu desenvolvimento intelectual, criando assim a classe de "anormais de inteligência" à qual se refere Basilio de Magalhães. Esta reorganização proposta por ele provocou uma ruptura no enquadramento médico da inteligência, pois ele transpõe para o domínio da patologia mental o modelo de Claude Bernard, ${ }^{166}$ assimilando os idiotas ao estado normal ao reduzir suas diferenças a variações de ordem quantitativa de uma mesma função vital. A classificação da idiotia, diz Binet, é uma classificação clínica a ser realizada pela psicologia, e é esta classificação que Basílio de Magalhães segue. Apesar da escala permitir afirmar a superioridade da psicologia experimental sobre a medicina em matéria de classificação clínica dos idiotas, no caso do Brasil as

\footnotetext{
${ }^{165}$ Conforme pesquisa realizada por PINELL, Patrice. "L'invention de l'echelle métrique de l'intelligence". Actes de la recherche en sciences sociales 108, juin 1995, pp.18-35. As análises sobre Binet foram realizadas a partir dessa pesquisa.

166 Sobre Claude Bernard e a patologia experimental, ver CANGUILHEM, Georges. $O$ normal e $o$ patológico, 1995. Como se sabe, suas pesquisas procuraram demonstrar a continuidade entre os fenômenos normais e os fenômenos patológicos.
} 
decisões de orientação educacional das crianças anormais parecem não ter saído das mãos dos médicos, conforme veremos no capítulo $6 .{ }^{167}$

Goddard $^{168}$, tradutor e introdutor dos testes de Binet nos EUA, ${ }^{169}$ e diretor da Escola Prática de Vineland (New Jersey) para meninos e meninas débeis mentais, esteve preocupado em criar uma escala única, uma classificação unilinear que abarcaria desde os idiotas até os débeis. Um Comitê especial para terminologia psicológica formado pela American Psychological Association anunciava em 1920 o projeto de uniformizar o "uso preciso de termos com dois ou mais significados, e termos usados indefinidamente ou de forma ambígua nos escritos psicológicos”.

${ }^{167}$ Os testes de QI não só se tornaram uma indústria, como também, o motor de todo um ramo da psicologia. Esse desenvolvimento foi impulsionado pelo uso em massa dos testes de inteligência no exército americano, durante o final da primeira guerra mundial. Mais uma vez haveria convergência de interesses profissionais e necessidades governamentais, como houve no caso de Binet e Simon. Para atingir seus objetivos os psicólogos americanos tiveram que modificar a tecnologia de Binet. Os procedimentos de Binet eram mais próximos do modelo médico, e dependiam de uma interação entre o profissional e a criança. No caso do exército americano, os testes foram aplicados em grupos imensos de homens ao mesmo tempo, e muitas vezes sob condições de desconforto. Houve uma simplificação em formato de múltipla escolha. As condições militares deixaram suas marcas nos testes de inteligência e forçaram sua conversão em um rápido emprego em populações em termos de sua validade mental. Esta conversão gerou a base indispensável para os debates ideológicos a respeito de diferenças raciais e QI, e o uso em massa de testes de inteligência no sistema educacional entre os anos 20 e 30. Mas a influência militar não parou por aí. Foi introduzida a contagem do tempo. As autoridades militares valorizavam velocidade e apelo ao comando. e as condições do teste deveriam refletir essas prioridades. A categoria inteligência passou a ter um papel maior na forma como as instituições racionalizaram suas políticas de seleção e decisões. Historicamente, o passo crucial para a sobrevivência científica do conceito de inteligência foi estabelecida por um vínculo indissolúvel entre uma certa concepção de inteligência e uma tecnologia específica. Ainda conforme DANZIGER, Kurt. Naming the mind. How psychology found its language, 1997, p.69. Ver capítulo intitulado "Putting intelligence on the Map".

${ }^{168}$ Sobre Goddard, ver GODDARD, Henry Herbert. The Kallikak family. A study in the heredity of feeblemindedness, 1912. Ver também GOULD, S.J. A falsa medida do homem, 1991, capítulo "A teoria do QI hereditário".

169 Segundo Danziger, é notável que em 1908, quando os investigadores anglo-saxões tiveram contato com os testes de Binet, não houve dificuldade em assimilar o rótulo inteligência a partir de um esquema conceitual preexistente. Conforme DANZIGER, Kurt. Naming the mind. How psychology found its language, 1997, "Putting intelligence on the Map". 
Entre os termos mais problemáticos o comitê apontava as palavras "intelecto" e "inteligência", utilizados por autores de forma não intercambiável. O Comitê tinha também como objetivos a tradução padronizada de termos estrangeiros, considerada "assunto de primeira importância para qualquer ciência que pretendesse esclarecer significados duplos e sinônimos imperfeitos". ${ }^{170}$

No que se refere à criminalidade infantil, para Goddard o principal fator determinante da conduta humana era um processo mental chamado inteligência. E esse processo seria condicionado por um mecanismo nervoso inato. O raciocínio seguia: o grau intelectual que cada indivíduo alcançaria dependia do tipo de cromossomo contido nas células germinativas. E que, salvo acidentes graves, as influências posteriores incidiam de forma reduzida sobre a inteligência. Para Goddard, a maior parte dos comportamentos indesejáveis se devia a uma deficiência mental hereditária dos infratores. A criminalidade infantil não seria causada pela estupidez mas pela combinação entre deficiência mental e imoralidade. A inteligência controlava as emoções; portanto, quando a inteligência é pouca as emoções não são controladas. Para ele, a inteligência normal era dominante, e se transmitia de maneira mendeliana. ${ }^{171}$

\footnotetext{
${ }^{170}$ Conforme American Journal of Psychology, v.31, n.2, 1920, p.220.

${ }^{171}$ Com Mendel (1822-1884) os fenômenos da biologia adquirem rigor matemático. Haveria uma lógica interna que impõe à hereditariedade um tratamento estatístico e uma representação simbólica. Sobre Mendel, ver JACOB, François. La logique du vivant, 1970, p.225 e seguintes.
} 


\section{Caráter e imoralidade: a psicologia nos tribunais de almas vacilantes}

As diversas políticas de segregação das crianças criminalizadas que começaram a adquirir um caráter cada vez mais sistemático a partir do final do século XIX foram legitimadas no contexto científico da criminologia. Foi assim que, em 1899, por meio do Juvenile Court Act de Illinois (EUA), criou-se o primeiro tribunal para crianças. ${ }^{172}$ Trinta anos depois, esses tribunais constituíam realidade em número considerável de países: Inglaterra (1905), Alemanha (1908), Portugal (1911), França (1912), Japão (1922) e Espanha (1924). Na América Latina foram criados em 1921 na Argentina, em 1927 no México e em 1928 no Chile. ${ }^{173}$

Os tribunais especiais para crianças podem ser, portanto, considerados uma criação americana e foram rapidamente adotados por diversos países. ${ }^{174}$ No Reino Unido o sistema foi generalizado pelo Children Act de 1908, mas bem antes desta data foi aplicado em várias cidades inglesas. As medidas adotadas pelos tribunais

\footnotetext{
${ }^{172}$ A Juvenile Court não foi uma reforma radical, mas a consolidação de práticas já consolidadas. Ver PLATT, Anthony M. The child savers, 1977, capítulo 6: "The fate of the Juvenile Court".

${ }^{173}$ Ver MENDEZ, Emilio Garcia. Infância e cidadania na América Latina, 1998.

${ }^{174}$ NACHÂT, Hassa. Le jeunes délinquents, 1913.
} 
infantis diferiam da justiça criminal comum em vários aspectos: os menores não poderiam ser julgados em audiências ordinárias; o menor de 16 anos não poderia ser detido nas casas de correção ordinárias da polícia, a não ser em circunstâncias especiais; e também a possibilidade de adoção do sistema de liberdade vigiada, inexistente no sistema penal adulto. Segundo Nâchat, na Alemanha em 1908 cerca de setenta cidades já haviam criado tribunais desse tipo.

No Brasil, já alguns anos a criação dos tribunais para crianças foi a consolidação de discussões como a apresentada em 1920 por Noé Azevedo, em sua dissertação apresentada à Faculdade de Direito de São Paulo, sugerindo a criação de tribunais especiais para menores delinquentes. ${ }^{175} \mathrm{O}$ argumento jurídico baseava-se na idéia de que a delinquência precoce era resultante dos efeitos de uma sociedade regida pelo capitalismo industrial, que provocava desorganização econômica, aglomeração nos centros urbanos e promiscuidade dos lares pobres: "É condição de vida do industrialismo-capitalista hodierno o emprego nas fábricas das mães e dos menores. (...) Os filhos, que por mui pequenos ainda não servem nas oficinas, não havendo quem os retenha em casa durante a ausência dos pais, vão para a rua, levados pela sua curiosidade natural, em busca de aventuras. Privados da melhor escola do bem que é o lar, cedo se matriculam na grande escola do mal que é a rua. (...) Correr e gritar pelas ruas, querem coisa mais conforme ao temperamento irrequieto dos menores?", alerta o autor. ${ }^{176}$

\footnotetext{
${ }^{175}$ AZEVEDO, Noé. Dos tribunaes especiaes para menores delinquentes e como podem ser creados entre nós, 1920.

${ }^{176}$ A crítica ao "industrialismo" também viria pelo lado dos anarquistas, que alertavam para as péssimas condições de trabalho impostas às crianças. Ver PASSETTI, Edson. "Crianças carentes e políticas públicas", 1999, p.350 e seguintes.
} 
Dada a complexidade caótica do industrialismo capitalista, era preciso entender a vasta família degenerativa, como pregava Ingenieros, a quem o autor recorreu como autoridade no assunto: "Na vasta família degenerativa todos os grupos têm deficiências mentais próprias; cada um oferece uma psicologia especial, que lhe é peculiar e pela qual se distingue. A do homicida não é a mesma do invertido, a do paranóico não é a mesma do cleptomaníaco, a do suicida difere do impulsivo, a do tímido diverge da que apresenta o mentiroso".

Dada tamanha complexidade, o autor se pergunta: "Seria concebível que a mentalidade curta, obtusa e lerda de um júri fosse capaz de destrinchar o mais simples dos problemas psicológicos? Há profissões que estão ao alcance de todos, muitas são difíceis, mas com esforço podem ser apreendidas. Mas há certos estudos que dependem de uma vocação, de uma tendência ou intuição especial. A psicologia está nesse caso. Todo o mundo pode saber psicologia, mas muito poucos serão psicólogos", conclui o autor.

Um dos introdutores do positivismo na Argentina, Jose Ingenieros afirmava que a mediocridade moral era impotência para a virtude e covardia para o vício: "A evolução das virtudes depende de todos os fatores morais e intelectuais. O cérebro deve antecipar-se ao coração; mas nossos sentimentos influem mais intensamente em nossas idéias na formação dos critérios morais". ${ }^{177}$ Para ele, a moralidade seria tão importante quanto a inteligência na composição global do caráter, sendo que o trabalho seria a melhor escola contra a mediocridade moral.

A desigualdade interna entre os humanos passa a ser a questão para a qual a psicologia vem trazer um novo saber: "A nova escola diz que não é justo tratar

${ }^{177}$ INGENIEROS, J. El homem mediocre [1913] p.58. 
igualmente a seres desiguais. As desigualdades dos criminosos são internas, não são físicas mas psíquicas. Para percebê-las é necessário um senso especial, que nem todos os homens são capazes de adquirir”, adverte o jurista. É portanto necessário que o juiz tenha conhecimentos de psicologia, o que segundo o autor seria mais importante do que a própria atuação da polícia. Contudo, era preciso ficar alerta contra os aventureiros: "Mas a psicologia não é a ciência fácil que todo o mundo pensa conhecer profundamente, dizendo os pretensiosos que nasceram com a boca de psicólogos tão fácil se lhes afigura conhecer os meandros mais obscuros da alma de seus semelhantes. A psicologia é uma ciência dessas que qualquer charlatão se diz conhecedor. Dizem que ela depende mais da intuição do que de estudos, e por isso não faltam sandeus que se não digam ungidos do óleo psicológico de que nos fala Hans Reichel".

Qual era a situação da nova ciência no Brasil? Uma avaliação nada otimista da presença da psicologia foi realizada por Farias Brito em capítulo de seu livro intitulado $A$ base physica do espírito ${ }^{178}$. Segundo ele, o solo da intelectualidade nacional não parecia propício para o desenvolvimento dessa nova ciência: ${ }^{179}$ "Em nosso país, infelizmente, não temos coisa alguma de que se possa aqui fazer menção. Se se perguntar: o que há, entre nós, sobre este relevantíssimo assunto que tanto tem despertado o interesse dos homens mais eminentes em todos os países cultos do mundo? - a resposta deverá ser esta: nada, absolutamente nada. De certo

\footnotetext{
${ }^{178}$ BRITO, Raimundo de Farias. A base physica do espirito. História summaria do problema da mentalidade como preparação para o estudo da philosophia do espirito, 1912. Aqui faço referência ao capítulo "A psicologia no Brasil".

${ }^{179}$ Sob esse aspecto, somente a partir dos anos 20 a indústria editorial paulista teria um desenvolvimento acelerado, envolvendo livros, revistas, folhetos e aumento da tiragem de jornais como O Estado de S.Paulo, que passou a compor um corpo de articulistas e redatores que envolvia intelectuais brilhantes do país, além de celebridades da imprensa européia como colaboradores permanentes. Conforme SEVCENKO, Nicolau. Orfeu estático da Metrópole, 2000, p.95.
} 
temos pensadores isolados que devem conhecer a fundo o movimento atual da psicologia. Mas estes, ou não se sentem com coragem para atacar os preconceitos dominantes, ou não querem perder o seu tempo, dedicando-se a trabalhos para os quais ainda não se acha preparada a atmosfera intelectual de nossa pátria”.

Farias Brito não acreditava que o solo da intelectualidade nacional fosse terreno apropriado para a semente da nova ciência: "E o que pretender aí cultiva-la, arrisca-se a sofrer a decepção daquele que semeia a rocha bruta, sobre pedregulhos, onde a planta não pode criar raízes, ou entre espinhos que a não deixarão crescer. $\mathrm{O}$ certo é que ninguém quis ainda reagir contra a nossa esmagadora esterilidade no que diz respeito ao estudo do espírito humano, isto é, no que diz respeito ao estudo de nossa própria natureza e significação mais profunda".

Farias Brito não se referia apenas à uma psicologia experimental. Ele questionava legisladores e pedagogos pela ausência do ensino da psicologia, com exceção de escolas normais, com proporções bastante limitadas, uma vez que tratava-se de psicologia no que se referia diretamente à organização pedagógica do ensino. Para ele, a cadeira de clínica psiquiátrica de moléstias nervosas nas escolas de medicina indicava no próprio título que se tratava do elemento psíquico somente do ponto de vista médico da patologia mental, isto é, das moléstias do espírito ou, mais precisamente, das moléstias nervosas. "De maneira que se o que há sobre psicologia é somente o que se ensina em nossas escolas de medicina, pode dizer-se que em nosso país a única psicologia que foi julgada digna de estudo é a dos loucos", lamentava-se Faria Brito. 
Farias Brito escreve no momento em que o Conselho Superior de Instrução passa a incluir a disciplina psicologia no curso preparatório e exame de admissão para as Faculdades de Direito, idéia que - segundo ele - partiu da Faculdade de Direito de São Paulo, onde Noé Azevedo defenderia sua tese. A inclusão só seria possível, se os chamados "sacerdotes do positivismo não entendessem que há aí uma concessão feita à metafísica", alfineta Farias Brito. Para ele, era previsível que quase exclusivamente nas faculdades de direito se cultivasse as ciências de ordem filosófica e psíquica, pois "o direito é, já de si, uma ciência psíquica; é uma ciência aplicada que se funda sobre a psicologia, nas mesmas condições que a engenharia se funda sobre a matemática nas mesmas condições que a medicina se funda sobre as ciências naturais". 180

Sendo entendido o direito como uma ciência psíquica, o tribunal para menores não deveria ser visto como um simples tribunal, mas sim como um órgão que centralizasse os serviços públicos propostas à infância abandonada, criminosa ou em perigo moral, colocando todas as instituições sob as vistas de um só magistrado, o juiz de menores. Colocava-se que a principal missão dos tribunais consistia em uma espécie de laboratório para estudo do menor, de sua personalidade e de seu ambiente. ${ }^{181}$ Tendo por base estes conhecimentos, seriam adotadas as medidas mais adequadas para sua salvação moral e social. Apesar do título, esses organismos não deveriam julgar, mas examinar o caso particular, como o médico

\footnotetext{
${ }^{180}$ Farias Brito, A base physica do espirito, 1912, pp.277-280.

${ }^{181}$ Interessante ressaltar que juristas norte-americanos entendiam os tribunais especiais para crianças como "laboratórios para estudos do comportamento humano", onde os juízes deveriam ser "especialistas na arte das relações humanas". PLATT, Anthony M. The child savers, 1977, p.143.
} 
examina o enfermo para aplicar o remédio mais apropriado ${ }^{182} \mathrm{~A}$ idéia de que a justiça pudesse ser "personalizada" estava na base dos tribunais para crianças. Havia uma preocupação com a cena do tribunal, buscando tornar as salas mais "pessoais e privativas", nada parecidas com a corte criminal tradicional. A corte deveria ser uma simples sala, com uma mesa e duas cadeiras, onde o juiz e a criança ficariam em contato próximo. O juiz era aconselhado inclusive a colocar o braço no ombro da criança, aproximando-se para ganhar sua confiança, sem com isso perder sua "dignidade judicial".

Os tribunais apresentariam assim um aspecto "anti-legal", no sentido de que encorajariam um procedimento formal mínimo e um máximo de dependência em fontes "extra-legais". ${ }^{183}$ No Brasil, na base da formulação dos tribunais estava a crença nos poderes de mais uma 'nova ciência', que não era a psicologia: "Os alicerces da sociedade futura, sadia e honesta serão fundados por uma ciência mais nova ainda que a criminologia, porém de tão amplos e alevantados ideais que, alguém já disse, mais parece religião do que ciência: é a eugenia”, vibra Noé. A eugenia é aqui vista como uma ciência que estudaria e apregoaria os métodos para a prevenção de males implacáveis contra a alma vacilante entre o bem e o mal. Nessa linha, o trabalho de prevenção deveria começar na escola, com um exame médico, dada a "grande proporção de crianças anormais" nas carteiras escolares. Na escola profissionais emergentes fariam uma criteriosa classificação das crianças "que

\footnotetext{
182 O Código de Menores implantado em 1927 definiria oficialmente um espaço de atuação do médico psiquiatra no juízo de menores, ao qual caberia realizar uma inspeção médica para o conhecimento do menor. Conforme ALVAREZ, Marcos César. A emergência do Código de Menores de 1927: uma análise do discurso jurídico e institucional da assistência e proteção de menores, 1989, p.128.

${ }^{183}$ Conforme análise realizada por PLATT, Anthony M. The child savers, 1977, p.141.
} 
sofrem de anomalias mentais", prescrevendo para cada caso um tratamento científico e especial.

Era preciso, segundo este discurso, estar alerta para a influência nefasta que exercia sobre a criança um lar onde reinava a imoralidade, "quer seja o cérebro da criança a massa ainda virgem e facilmente amoldável de que falam os psicólogos positivistas; quer seja a criança um ser complicadamente formado". Seguindo um raciocínio fatalista, Noé Azevedo chamava a atenção para o fato da ação corruptora ter início desde a concepção: "Sem a menor higiene, estupidamente concebidos, crescem nas entranhas de desgraçadas mulheres que, extenuadas do labor das fábricas, só vêm à casa para receber maus tratos de machos embriagados".

Diante desse quadro, o único estudo específico dos delinquentes seria o de seu funcionamento psíquico. Para verificar as desigualdades dos criminosos, que agora são internas (não são físicas, mas psíquicas), era necessário um senso especial, que nem todos os homens seriam capazes de adquirir. Sendo a criminalidade precoce o grande mal a combater, a penologia deveria portanto esmerar-se na escolha de medidas próprias para a reforma dos jovens delinquentes. Tal tarefa só poderia ser levada a cabo por meio de um órgão distribuidor de penas que estivesse apto para conhecer a natureza e a constituição psíquica do menor criminoso, a fim de lhe aplicar o tratamento adequado.

$\mathrm{Na}$ base desse argumento haveria o entendimento da precocidade como característica da criminalidade moderna. Para combatê-la era necessário que se criassem órgãos capazes de compreender a individualidade dos delinquentes e suas anomalias. "Enfim, para se compreender a alma das crianças, que é complexa e 
delicada, a fim de ministrar-lhes tratamento eficaz para regenerá-las quando corrompidas, e de evitar que tomem o caminho do mal se ainda puras, tornam-se indispensáveis órgãos julgadores especiais que são os tribunais para menores", conclui Noé Azevedo. Era preciso punir, mas bondosa e paternalmente, dada a dificuldade em lidar com a alma vacilante das crianças: "Na criança nada se vê de estável ou permanente: as idéias são confusas ainda, os pensamentos incompletos; a volubilidade dessa alma em formação", alerta Noé.

As discussões em torno de um tribunal especial para crianças haviam chegado ao senado federal três anos antes pelas mãos de Alcindo Guanabara, que em 1917 reeditou um projeto apresentado havia dez anos. Guanabara já havia apresentado em 1906 um projeto que era, segundo o próprio autor, em sua essência, o mesmo que submetera à apreciação do senado em 1917. O primeiro projeto havia sido rejeitado por propor modificações no regime do pátrio poder e alterações quanto à responsabilidade criminal dos menores. Como o código civil e uma reforma do código penal estavam pendentes, as medidas foram adiadas. O projeto visava uma organização definitiva da infância chamada abandonada e delinquente, e portanto exigiria uma fatia razoável do orçamento. Optou-se então por organizar um serviço de assistência que atendesse as urgências do momento.

$\mathrm{Na}$ época, apesar de aprovado em primeira discussão, o projeto foi substituído pela proposta que a comissão oferecia, ou seja: “Organiza-se um serviço de asilos para os dois sexos, sob a jurisdição dos juízes de órfãos, asilos nos quais serão internados os menores abandonados (...) Este serviço, sob a administração do chefe de polícia, já existe com caráter provisório. A comissão pensa que ele deve 
ser ampliado, definitivamente mantido sob a mesma administração e, neste sentido, formulou o seu substitutivo". ${ }^{184}$ Esse substitutivo transformou-se em lei que vigorou por dez anos, até Guanabara apresentar mais uma vez seu projeto.

$\mathrm{Na}$ apresentação de seu novo projeto, Guanabara faz referência a relatório do Ministro Carlos Maximiliano, da Justiça e Negócios Interiores, em que descreve as condições às quais as crianças eram submetidas: "como escassa a verba - Obras preparei em uma dependência da Detenção um aposento arejado e vasto para os menores encarcerados. O depósito provisório para cinquenta crianças converteu-se em asilo permanente para 380 , porque não havia para onde mandá-los". Segundo dados do Gabinete de Identificação e Estatística, entre 1907 e 1912 era a seguinte a relação entre idade e número de criminosos recolhidos pela polícia do Distrito Federal: até 15 anos 240; de 16 a 20 anos, 2322. ${ }^{185}$

$\mathrm{Na}$ defesa de seu projeto, Guanabara argumenta que já era hora do Estado intervir em assuntos que não eram apenas "políticos", e marca sua posição contra aqueles que chamava de darwinistas sociais: "Já não há, felizmente hoje em dia, quem reconheça fóros de verdade naquela espécie nefasta de darwinismo social, que nos queria dar como lema e destino a luta pela vida, o isolamento individualista, o combate pelo lugar ao sol, e a impossibilidade e a frieza inflexível com que o Estado visse o mais fraco tocar os ombros da terra e receber no seio até os copos, a adaga cruel do vencedor!”.

\footnotetext{
${ }^{184}$ GUANABARA, Alcindo. Pela infância abandonada e delinquente do Distrito Federal. Exposição de motivos e projecto de lei apresentado ao Senado Federal na Sessão de 21 de agosto de 1917, 1917, p.7.

185 Conforme GUANABARA, Alcindo. Pela infância abandonada e delinquente do Distrito Federal. Exposição de motivos e projecto de lei apresentado ao Senado Federal na Sessão de 21 de agosto de 1917, 1917, p.10.
} 
O projeto de Guanabara criava na parte central da cidade um "depósito de menores", com separação dos sexos, dividido em aposentos individuais em que cada criança não poderia permanecer por mais de três dias. Na própria definição do autor, o projeto era um sistema, uma engrenagem em que todas as peças deveriam estar interligadas. Após esse primeiro período, dali sairia o menor ou para o seio da família, "se a tem em condições de capacidade para recebê-lo e educá-lo, ou, por ordem e sentença do juiz para uma escola de prevenção se for apenas abandonado e candidato possível ao crime, ou para uma escola de reforma, se já houver delinquido, quer fosse absolvido, quer fosse condenado". A hierarquia institucional estabelecida organizar-se-ia da seguinte forma, dependendo da gravidade do caso: família, prevenção, reforma.

Segundo Guanabara, sua proposta não resolveria aquilo que chamava de complexo problema social provocado pela criminalidade precoce: "Não esqueço que esta solução exigiria que se tomasse a criança ainda no ventre materno, acompanhando-a na primeira infância e preservando-a das faltas de higiene e de saúde moral, nos infernais pandemônios que são as hospedarias e as casas de cômodos, a que infelizmente está condenado, por desatenção e indiferença dos poderes públicos federais e municipais, o proletariado brasileiro (...) As pobrezinhas sentem-se coagidas a buscar na rua o que lhes falta nos compartimentos acanhados em que moram: um pouco de ar, um pouco de luz... Mas na rua o ar e a luz vêem misturados com as emanações dissolventes do caráter, com os espetáculos deprimentes, com todas as solicitações da infâmia". ${ }^{186}$ Segundo Guanabara, a

\footnotetext{
${ }^{186}$ GUANABARA, Alcindo. Pela infância abandonada e delinquente do Distrito Federal. Exposição de motivos e projecto de lei apresentado ao Senado Federal na Sessão de 21 de agosto de 1917, 1917, p.22.
} 
situação havia se agravado nos últimos anos depois das grandes obras de embelezamento da cidade do Rio de Janeiro.

Em relação ao primeiro projeto, Guanabara considerava apenas uma idéia nova e fundamental: a criação do juízo privativo para a proteção, defesa, processo e julgamento dos menores, com a consequente reforma do processo, que não seria mais escrito, e das audiências, que passariam a ser secretas. Havia ainda a proibição da imprensa de divulgar o andamento dos processos, ficando conferida ao juiz a faculdade de proferir sua decisão de consciência, sem se subordinar à rigidez das regras do Código Penal. Confirmava-se assim a condução dos processos nos tribunais de modo a enfatizar aspectos extra-legais. Os tribunais eram reconfigurados, desta forma, como órgãos capazes de compreender a individualidade do delinquente.

Como seria o tribunal proposto por Guanabara? Não seria o modelo do tribunal coletivo, que contaria com a participação também de professores e médicos, além do juiz. O tribunal coletivo em que participassem médico, um jurista e um professor não the despertava entusiasmo por ser, segundo ele, apenas um tribunal para julgar, "depois de longos discursos, em que cada qual procuraria fazer valer os seus estudos especiais e a sua erudição, nem sempre aplicáveis ao caso concreto do infante delinquente cujo destino lhe está nas mãos". Guanabara tampouco confiava na praticabilidade do probation system, questionando a seriedade da vigilância das crianças e adolescentes pelos profissionais que se tornariam agentes de segurança, dada a remuneração irrisória que o Estado poderia lhes garantir. 
Guanabara preferiu centralizar o processo na figura do juiz, segundo ele "um juiz togado que pode ser recrutado no mais alto tribunal local, habituado a julgar, que tome a si a proteção e a defesa do menor em abandono e que julgue o menor delinquente, em consciência, informando-se por si mesmo das suas condições, do meio em que vive, do concurso de circunstâncias que o fizeram criminoso. Este juiz será, na frase da lei portuguesa, um 'bom pai', que saberá prever, aconselhar, repreender e corrigir", explica Guanabara, acrescentando que deveria ser remunerado fartamente, "para exigir dele que dê a essa grande obra social toda a sua dedicação". O projeto preferiu estabelecer, como regra, que o menor considerado abandonado e o menor delinquente 'absolvido' fossem, desde logo, por ordem do juiz, recolhidos a uma escola de reforma, "que não são prisões, mas escolas, onde formarão o caráter e se aparelharão para a vida segundo o lema da lei portuguesa: educação e trabalho". Na visão de Guanabara, os ofícios propostos para os menores internados nas escolas masculinas seriam jardinagem, sapateiro, alfaiate, funileiro, carpinteiro, tipógrafo, encadernador ou música instrumental. Às meninas caberiam as opções de bordadora, engomadora, lavadeira, cozinheira, música coral ou datilógrafa.

Quanto à questão do discernimento, o regime deste projeto procurou simplesmente diminuir o peso dado a esta polêmica, por considerar uma inovação radical demais abolir de vez o critério do discernimento, o que só ocorreria alguns anos depois. Não era preciso atacar frontalmente o discernimento, pois seu conteúdo já estava esvaziado. O autor resolveu então elevar apenas o limite de idade da imputabilidade de 9 a 12 anos, segundo ele "porque realmente nada justifica 
entre nós tão baixo limite". A questão do discernimento passaria a ser examinada pelo juiz dos 12 aos 17 anos, tendo como parâmetros "a situação de responsabilidade do menor; pela sua educação ou pelo seu estado de abandono, pela miserabilidade, pelas condições morais do meio em que vivia". ${ }^{187}$

Desloca-se portanto a questão do crime para o estudo do caráter do criminoso, cujo resultado selaria o destino da criança: escola de prevenção ou escola de reforma. A preocupação do juiz "não há pois de ser tanto a do crime ou delito praticado, com ou sem responsabilidade, como a do estudo do caráter do menor, de seu grau de corrupção, da esperança que ele pode dar de aperfeiçoamento ou de regeneração". A questão do discernimento tornava-se irrelevante, uma vez que passa a ser indiferente saber se o menor é ou não capaz de imputabilidade: “é positivamente tempo perdido discutir se essa imputabilidade é uma função da idade, desde que, preliminarmente admitimos que o é das condições personalíssimas do menor e das circunstâncias do meio em que se fez criminoso".

O discernimento era um ponto de discórdia, chamado de questão enigma, questão falida ou "problema psicológico", mesmo entre aqueles que defendiam o probation-system, como Campello: ${ }^{188}$ "A medida de temibilidade do delinquente não se deduz do delito cometido, senão de um estudo psicológico individual, que é dado para interpretar o valor anti-social do seu ato delituoso e a escala de medida da imoralidade da sua conduta". Campello esclarece que além do exame médico no

\footnotetext{
${ }^{187} \mathrm{O}$ projeto de Guanabara ficou sem continuidade com a morte de seu autor. Mas será a partir desse projeto que o deputado federal e criminalista Mello Mattos elaborará um substitutivo anos depois. Mello Mattos fora diretor do Lyceu Pedro II e nomeado Juiz de Menores em 1924, quando começou a trabalhar na elaboração de código de menores. O Presidente Washington Luis lhe confiaria a redação do novo código, que seria aprovado em outubro de 1927. Conforme ALVAREZ, Marcos César. A emergência do Código de Menores de 1927, 1989, p.111.

${ }^{188}$ Conforme CAMPELLO, Barreto. Da individualização da pena, 1927.
} 
início da instrução do processo, o menor deveria passar pelo probation-system, seguindo o regime norte-americano, que fazia uma classificação moral do delinquente. A classificação moral consistia na divisão das crianças segundo seu grau de mérito em diversas categorias chamadas 'seções': maus, bons e melhores, a partir da qual as crianças eram classificadas segundo um engenhoso sistema de pontos conferido a cada mês: 4 para comportamento, 4 para asseio, 4 para economia, 4 para emprego do tempo disponível, 4 para observância do silêncio, 4 para aplicação ao estudo, 4 para aplicação ao trabalho, 16 para emenda.

Apesar de chamar de escola de prevenção ou reforma, a regeneração dessas crianças não poderia ser realizada apenas pela instrução: "Só a instrução literária é insuficiente de todo para essa obra sutil e delicada do combate às taras ancestrais e da reorganização das almas deformadas antes mesmo da vida e tão cheias de deturpações e de tortuosidades". Sentimentos e emoções passam a ser fundamentais da formação do caráter: "A ação da instrução por si só é nula na formação do caráter, que depende de sentimentos e de emoções que ela é impotente para despertar e mais ainda cultivar", conclui Campello.

A crítica a certos procedimentos judiciais era parte da disputa travada entre médicos e juristas em torno da criança criminalizada. A discussão sobre a criação de tribunais especiais envolveu juristas como Evaristo de Moraes, que publicou em 1916 Criminalidade da infância e da adolescência. ${ }^{189}$ É de 1910 um projeto de reforma processual criminal citado por ele, elaborado por uma comissão de juristas

\footnotetext{
${ }^{189}$ MORAES, Evaristo de. Criminalidade da infância e da adolescencia, 1927. Foi utilizada a segunda edição. Moraes popularizou-se como defensor dos pobres principalmente através de artigos publicados na grande imprensa, além de ser um dos fundadores do Partido Operário (1890) e do Partido Socialista (1920).
} 
presidida pelo Ministro da Justiça, que continha regras relativas ao processo de menores de 14 anos, instituindo um tribunal juvenil composto por um jurista penitenciarista, um médico "physiologista" e um pedagogo, seguindo o modelo de tribunal coletivo criticado por Guanabara. No projeto, a criança ou jovem deveria ser submetido a exames médico-legais, que constatariam, "além do seu desenvolvimento físico e psíquico, seu estado mental". A comissão para estudar o projeto dissolveu-se, contudo, sem concluir os trabalhos.

Evaristo de Moraes apontava um aumento da criminalidade da infância e da adolescência, "revelando-se mais precocemente os impulsos anti-sociais". Segundo ele, o aumento não se devia apenas a fatores individuais, como a hereditariedade. Citando Morel, o autor afirma que "trata-se principalmente da ação debilitante exercida sobre o embrião humano, pelas más condições em que ele se desenvolve”. Ganhavam força os argumentos que apontavam o "industrialismo" como causa social da criminalidade: "A criança nascida de pais debilitados por excesso de trabalho e por falta de alimentação suficiente pode ter o aspecto comum de todas as crianças, mas provavelmente desde os primeiros tempos de seu contato com o torvelinho social, se mostrará pouco apta, inferior aos da sua idade, dificil de educar [grifo no original], propensa à ociosidade e às sugestões dos criminosos". Como Apêndice, o autor apresenta um estudo sobre a prostituição na infância e na adolescência, segundo ele "a face feminina da criminalidade", e que teria as mesmas causas da criminalidade masculina.

A ciência psicológica também contribuía para que a sexualidade fosse um novo elemento explicativo da infância criminalizada: "Causa ou fato individual de 
alta relevância - e bem poucas vezes tomado em consideração - é quanto aos crimes dos adolescentes, a transformação provocada pelos fenômenos próprios da puberdade. Fala-se muito em criminalidade infantil, quando mais intensa, mais alarmante, é a criminalidade juvenil. Para as manifestações desta última a ciência psicológica fornece algumas explicações dignas da atenção dos criminalistas. O irrompimento da puberdade ocasiona mudanças sensíveis no organismo e essas mudanças refletem nos atos bons e maus da criatura humana". A informação Evaristo de Moraes trazia do então professor de Psicologia e Pedagogia da Universidade Clark, G. Stanley Hall, cuja bibliografia é recomendada pelo autor.

Os tribunais especiais para crianças foram criados no Rio de Janeiro, pela lei 4242 de 1921. No estado de São Paulo pela lei 2059 de 31 de dezembro de 1924 foi criado, pelo presidente do Estado de São Paulo, o cargo de juiz privativo de menores, na comarca da capital, que se constituía de um juiz, um curador ou promotor, um médico, um escrivão, um escrevente habilitado, três comissários de vigilância sendo uma mulher, dois oficiais de justiça, um servente e porteiro. Os menores eram julgados e processados pelo juiz de menores, não havendo inquérito policial. A lei paulista também criou um conselho de assistência e proteção aos menores, conforme a lei federal. Pela nova lei, o Instituto Disciplinar da capital ficou sob imediata e constante superintendência do Juiz de menores. O Instituto compreendia então 3 seções, que classificavam as crianças da seguinte forma: menores simplesmente abandonados, menores pervertidos e menores delinquentes. Pela lei, o produto do trabalho executado no Instituto em horticultura, avicultura e congêneres era dividido em duas partes, uma das quais gerava renda para o Estado e 
a outra era distribuída proporcionalmente entre os internos e depositada na Caixa Econômica do Estado.

Com relação aos menores simplesmente abandonados, a questão da idade é deixada sem classificações ou graduações, ao critério do juiz, dentro do limite máximo de 18 anos. Quanto aos menores delinquentes, o critério legal de idade para efeitos de medidas a adotar passou a ser o seguinte: menores até 14 anos; menores de mais de 14 e menos de 18 anos; menores de mais de 16 e menos de 18 anos; menores de mais de 18 e menos de 21 anos. Essa lei de menores passou a definir como menor abandonado - entre outras - todo menor que, tendo menos de 18 anos, não tivesse habitação certa, nem meios de subsistência, por serem seus pais falecidos, desaparecidos, ou desconhecidos; se encontrasse eventualmente sem habitação certa, nem meios de subsistência, devido à indigência, enfermidade, ausência ou prisão dos pais, tutor ou pessoa encarregada de sua guarda; tivesse pai, mãe ou tutor encarregado de sua guarda, reconhecidamente impossibilitado ou incapaz de cumprir seus deveres para com o filho, ou pupilo, ou protegido; vivesse em companhia de pai, mãe, tutor ou pessoa que se entregasse à prática de atos "contrários à moral e bons costumes"; se encontrasse em estado habitual de vadiagem, mendicidade ou libertinagem contrárias "à moral e aos bons costumes", ou que lhe colocasse em risco a vida ou a saúde. Seriam considerados vadios os menores que, tendo deixado, sem causa legítima, o domicílio do pai, mãe, tutor, guarda ou lugares onde se achassem colocados por aquele a cuja autoridade estivessem submetidos ou confiados, fossem encontrados habitualmente a vagar pelas ruas ou logradouros públicos, sem que tenham meio de vida regular, ou 
tirando seus recursos de ocupação imoral ou proibida; seriam mendigos os menores que habitualmente pedem esmola para si ou para outrém, ainda que este fosse pai, mãe ou pedissem donativos sob pretexto de venda ou oferecimento de objetos. ${ }^{190}$

A legislação previa medidas comuns aos menores abandonados e delinquentes, como "apreensão, depósito e exame médico". O exame médico tinha por fim "verificar se o estado do menor exige um tratamento especial, notavelmente se ele sofre de qualquer forma de alienação ou insuficiência mental, ou se é epilético, surdo-mudo ou cego". Entretanto, medidas especiais eram aplicadas apenas aos abandonados. Nesse caso, competia ao juiz tomar uma das seguintes decisões: ou entregá-lo aos pais ou tutor sob condições que julgasse úteis à saúde, segurança e moralidade do menor; ou entregá-lo à pessoa idônea, ou interná-lo em hospital, asilo, instituto de educação, oficina, escola de preservação ou reforma.

O processo de verificação do estado de abandono no estado de São Paulo era sumaríssimo. Tinham competência para mover o processo o juiz, o curador especial de menores na comarca da capital e o curador geral nas demais comarcas, ou por denúncia de qualquer pessoa. Com a instauração do Código de Menores em 1927, os processos-crime também passariam a seguir essa lógica. Um menino de 15 anos foi internado no Instituto Disciplinar até completar a maioridade porque "não respeitava a autoridade das pessoas encarregadas de sua guarda, entregando-se a mais desenfreada vadiagem". ${ }^{191}$ Outro menino foi enviado ao Instituto Disciplinar

\footnotetext{
${ }^{190}$ Exposição analytica e commentada da lei federal n.4242 de 5 de janeiro de 1921 e seu regulamento aprovado pelo Decreto n.16.272 de 20 de dezembro de 1923, e da Lei Paulista n. 2059 de 31 de dezembro de 1924 por Joaquim Candido de Azevedo Marques. Ver: MARQUES, J. C. Menores abandonados e delinquentes, 1925. Azevedo Marques foi chefe de política e promotor público e escreveu o livro como juiz de direito.

${ }^{191}$ Juízo de Direito da $2{ }^{\text {a }}$ Vara. Processo de menor, Comarca de Santos [1930].
} 
porque, conforme testemunhas do processo, "não obedece a autoridade de seus pais entregando-se a vadiagem e a outras brincadeiras viciosas; passa dias e dias fora de casa sem que seus pais saibam notícias dele". ${ }^{192}$ Três irmãos, de 13, 12 e 6 anos, órfãos de pai e mãe, foram enviados ao Instituto Disciplinar de Mogy Mirim porque "se entregam a vadiagem sem respeitar a autoridade do tio e tutor". ${ }^{193}$ Crianças de 11 anos eram internadas até completar a maioridade por "não obedecer a autoridade das pessoas encarregadas de sua guarda". ${ }^{194}$

Muitas dessas crianças foram enviadas ao Hospital de Juquery após passagens pelo Instituto Disciplinar, conforme veremos no capítulo seguinte.

\footnotetext{
192 Juízo de Direito da $2^{\text {a }}$ Vara. Processo de menor, Comarca de Santos [1928].

${ }^{193}$ Juízo de Direito da $2^{\text {a }}$ Vara. Processo de menor, Comarca de Santos [1929].

${ }^{194}$ Juízo de Direito da 2 a Vara. Processo de menor, Comarca de Santos [1929].
} 


\section{Psicomoral e ineducabilidade: os pequenos psicopatas}

No Brasil, o momento da criação de instituições jurídicas próprias para as crianças coincidiu com a constituição de uma seção especial para elas no Hospital de Juquery. ${ }^{195}$ Mas não se trata apenas de uma conexão temporal: nos primeiros relatórios da seção é registrada a entrada de várias crianças oriundas do Instituto Disciplinar, ou encaminhadas pelos Juízes e Tribunais de Menores. Por sua vez, crianças internas da seção eram realocadas no Instituto Disciplinar, configurando um trânsito entre as instituições. Em tese apresentada à Faculdade de Medicina de São Paulo e analisada neste capítulo, Pedro Silva apresenta 15 casos de menores, sendo 8 procedentes do Instituto Disciplinar da capital.

A proposta de criação de uma "Secção para menores anormaes" partiu de seu primeiro diretor, Franco da Rocha, nos primeiros anos da década de 20, portanto mais de duas décadas após sua fundação, período no qual as crianças permaneciam nos pavilhões gerais, conforme o sexo: as meninas nos pavilhões femininos e os meninos nos masculinos, à semelhança do que ocorrera com as crianças em prisões antes das escolas correcionais. ${ }^{196}$ No início dos anos 20 Franco da Rocha já alertava para a superlotação de Juquery, exigindo a criação de um hospício só para mulheres. Ao assumir a primeira cadeira de psiquiatra e moléstias nervosas da

\footnotetext{
${ }^{195}$ A importância do Hospital de Juquery no contexto da saúde pública paulista se reflete nas cifras: em 1903, a instituição recebia cerca de metade do orçamento destinado ao Serviço Sanitário do Estado. Conforme CUNHA, Maria Clementina Pereira. O espelho do mundo, 1988, p.37.

${ }^{196}$ A permanência em pavilhões adultos não impediu que uma criança de 12 anos, internada em 1915, fosse encontrada morta após enforcamento com a própria calça. Conforme relato de CUNHA, Maria Clementina Pereira. O espelho do mundo, 1988, p.105.
} 
Faculdade de Medicina de São Paulo, Franco da Rocha salienta em seu discurso de posse o novo campo que se abre para a psiquiatria: o estudo das crianças anormais e de sua educação.

Em 1922, Franco da Rocha aplica parte da verba da Secretaria do Interior do Estado na construção de um primeiro pavilhão destinado às crianças do sexo masculino. Apesar de receber apenas crianças, o pavilhão seguia as regras da seção masculina: “Os menores eram assistidos por médico-alienista, já sobrecarregado com o trabalho de outras enfermarias. A assistência limitava-se, então, aos cuidados médico-higiênicos, sem vislumbre de qualquer medida pedagógica. Lotação oscilante entre 20 e 30 meninos. Pavilhão de construção antiga, com instalações primitivas, anti-higiênicas, exigindo, portanto, radical reforma". ${ }^{197}$

A defesa de exame psiquiátrico nas escolas estava diretamente relacionada à criação de estabelecimentos especiais para aquelas excluídas da vida escolar. ${ }^{198} \mathrm{Na}$ França, discutia-se as dificuldades terminológicas na definição dos mais diversos tipos de anomalia, termo que não poderia ser sinônimo de doença. A anomalia seria a tara de qualquer tipo estrutural, constitutiva do indivíduo, enquanto a doença deveria ser considerada um problema acidental da saúde. Haveria ainda que se fazer uma distinção fundamental entre o anormal físico e anormal psíquico, que seria definido como aquele que, sob influência de taras mórbidas, sobretudo hereditárias, apresentaria defeitos constitucionais de ordem intelectual e moral, associados

\footnotetext{
${ }^{197}$ BAPTISTA, Vicente. Seção de Menores Anormais do Hospital Central de Juquerí. In: Arquivos do Serviço de Assistência a Psicopatas do Estado de São Paulo. Ano III, pp.251258.

${ }^{198}$ Conforme HEUYER, Gerorges. Enfants anormaux et délinquants juvéniles. Necessité de l'examen psychiatrique des écoliers, 1914.
} 
geralmente a defeitos corporais, e para os quais se impunham métodos educativos especiais.

O tema do crime e da alienação mental exigia que se estabelecessem, portanto, as leis que regiam os fenômenos fisiológicos e psicológicos. Mas a ciência experimental que ditaria essas leis apenas começava a se desembaraçar das concepções de pura filosofia, uma ciência especulativa emprenhada de metafísica e teologia: "os laboratórios de fisiologia e psicologia que começam a tratar experimentalmente as faculdades humanas surtirão um dia as leis que permitirão conhecer cientificamente o homem normal e o anormal. Mas até o momento só há uma tentativa de ciência", conclui Heuyer em 1910. Contudo, o autor alertava para o fato de que "os progressos dessa ciência não resolverão o problema social do anormal, pois esses eram condicionados pela hereditariedade e sua adaptação social dependia da não-nocividade. Os anormais apresentavam certas reações ao meio que soariam como manifestações embrionárias das psicoses dos adultos, apresentando um retardo intelectual mais ou menos marcado. Esse retardo acentuaria com a evolução".

Segundo esse autor, essa classe de anormais poderia ser dividida em três graus: no grau mais baixo, onde as funções de relação eram mínimas, necessitariam de uma assistência completa. Corresponde à descrição clínica da idiotia e de uma parte da imbecilidade, e era acompanhada geralmente por uma tara física indiscutível. A educação dessas crianças seria impossível e se imporia sua internação. A um grau um pouco mais elevado certos anormais poderiam se recuperar a partir da assistência em um asilo ou patronato. Seriam os meio- 
adaptados (demi-adaptables), grupo no qual o autor inclui grande parte dos imbecis. Haveria ainda um grau mais elevado dos anormais psíquicos, que precisariam apenas de uma direção, podendo gozar de uma liberdade relativa: seriam os débeis ou anormais de escola primária (de Binet), os arriéres moyens et légers (de Régis), os feeble minded (de Warner e de Shutteworth), os deficienti et tardivi (de Sante de Sanctis) ou os Bildungsfähige da classificação alemã.

A crença na aliança anormalidade-crime levou o primeiro diretor do Hospital de Juquery, Franco da Rocha, a participar em 1921 da criação da Sociedade de Medicina Legal e Criminologia de São Paulo, no salão do Instituto de Hygyene da Faculdade de Medicina e Cirurgia, assumindo o cargo de vicepresidente. $\mathrm{O}$ eventou contou também com a presença de Alcantara Machado (presidente), Oscar Freire, Plinio Barreto, Roberto Moreira e Armando Rodrigues. Pelos estatutos, só poderiam ser aceitos como sócios médicos e juristas de nacionalidade brasileira, ou alunos matriculados nos últimos anos dos respectivos cursos. No discurso inaugural, Alcantara Machado reverencia Nina Rodrigues, e propõe-se a lançar as bases de uma criminologia nacional, afirmando que não se pode continuar a importar teorias, uma vez que o Brasil teria problemas específicos como a "capacidade mental das diferentes raças de que se compõe a população da República”. Na cerimônia também discursou Henrique Bayma, representando o Instituto dos Advogados, que declarou a todos os males do país: "a questão palpitante da infância abandonada e da infância delinquente; da degeneração e todas suas causas; da degeneração do rico pelo ócio e pelos vícios, ou do pobre pelos vícios e pela miséria; a prepotência da distribuição injusta das riquezas; a profilaxia 
de imigração". É de se estranhar então que entre as setenta Theses de Medicina Legal defendidas na Faculdade de Medicina de São Paulo entre 1919 e 1927, apenas uma trate da questão da criminalidade na infância. ${ }^{199}$

Ao assumir a direção do Hospital de Juquery substituindo o fundador, Antonio Carlos Pacheco e Silva deliberou ampliar e reformular o "serviço de menores". Ao regressar de viagem aos Estados Unidos e Europa em 1926, esboçou em relatório ao governo do Estado seus projetos para a construção de uma escola para aqueles que denominava "pequenos psicopatas". ${ }^{200}$ Três anos depois, em maio de 1929 era então inaugurada a Escola Pacheco e Silva, que em uma placa de bronze anunciava em sua entrada a seguinte frase: “A criança só praticaria o bem se só do bem lhe déssemos exemplo". ${ }^{201}$ A "secção para menores anormaes" inaugurava-se assim estruturada em dois pavilhões: o antigo pavilhão construído por Franco da Rocha em 1922 e um pavilhão-escola. Às meninas só restava continuar nos pavilhões adultos femininos.

A direção da nova seção ficou a cargo do médico Vicente Baptista, que assim expressava sua visão dos problemas da infância em São Paulo: “A situação, por exemplo, dos bairros paulistanos habitados por operários é simplesmente angustiosa. E quem duvide que desça, à tardinha, ao Braz, que vá ao Bom Retiro, perambule pelos cortiços sem ar e sem luz, onde há, em compensação, um luxo de

${ }^{199}$ Entre outras teses indicativas da presença da psicologia nessa área estão: "Condições psychológicas que influem nos accidentes de trabalho", de Messias Teixeira Camargo Filho [1922]; "Estudo medico-legal do grupo eschizofrenico", de Armindo Lacerda Guaraná [1923] e "Infanticídio", de Eugenio Frota de Souza [1923].

${ }^{200}$ PACHECO E SILVA, A.C. A assistencia a alienados nos Estados Unidos e na Europa. Relatorio de viagem apresentado ao Exmo. Snr. Dr. José Manuel Lobo, D.D. Secretario do Interior, em 24 de dezembro de 1926.

${ }^{201}$ Interessante notar o contexto "escolar" mais geral em Juquery. Em 1926, 38,5\% dos enfermeiros eram considerados analfabetos, a despeito de que saber ler, escrever e contar fossem as únicas exigências para o preenchimento dos cargos de enfermagem até 1922. Conforme CUNHA, Maria Clementina Pereira. O espelho do mundo, 1988, p.95. 
esterqueira. Por aí as crianças morrem como se fossem animais, ou vingam mirradas, enfermiças, completamente inutilizadas para o futuro. Tornam-se verdadeiros lastros sociais. Sob o ponto de vista eugênico melhor seria que tivessem morrido". ${ }^{202}$ Quando assumiu seu novo posto no Juquery, Vicente Baptista era autor de uma coluna no Diário de São Paulo, cujo título era "Conselho às Mães". Suas posições em relação à eugenia mostravam-se bastante incisivas: ${ }^{203}$ "a eugenia que se propõe a melhorar a raça diz já ser tempo de se deixar a seleção dos bois e dos cavalos para se tratar da seleção da humanidade". ${ }^{204}$

Ao relatar um caso de gêmeos "entrados" na secção de menores anormais, o diretor confirmava suas preferências científicas: "Nos últimos dias de dezembro ingressaram no pavilhão dois meninos que, por motivo de ordem interna, só foram registrados em 1933. (...) São gêmeos semelhantes no aspecto físico como duas gotas d'água. Epilépticos e idiotas completos. A feição patológica de um também se superpõe absolutamente a do outro. Nascidos a termo e em parto normal. Placenta única. Convulsões desde a terceira semana de vida. O pai é alcoolista incorrigível. A encefalografia mostra que os crânios e os centros são perfeitamente normais. Não há dúvida, pois, que se trata, nesses casos, de uma degenerescência plasmática pura.

\footnotetext{
${ }^{202}$ BAPTISTA, Vicente. O problema da assistencia e protecção á infancia. In: Pediatria Prática. Revista Mensal de Clinica Infantil e Puericultura, p.148.

${ }^{203}$ Segundo Lifton, o trabalho crucial sobre esta questão no período analisado foi publicado na Alemanha em 1920, intitulado A permissão para destruir a vida-não-digna-de-vida (Die Freigabe der Vernichtung lebensunwerten Lebens) e escrito por dois professores, o jurista Karl Binding (Universidade de Leipzig) e o professor de psiquiatria de Universidade de Freiburg, Alfred Hoche. O livro incluía entre a "lebensunwerten Lebens" não apenas doenças incuráveis mas também largos segmentos de doença mental, deficientes mentais e crianças consideradas deformadas e retardadas. Ver LIFTON, Robert Jay. The nazi doctors. Medical Killing and the Psychology of Genocide, 1986.

${ }^{204}$ BAPTISTA, Vicente. O problema da assistencia e protecção á infancia. In: Pediatria Prática. Revista Mensal de Clinica Infantil e Puericultura. v.3. julho de 1930. p.148.
} 
O interessante é que se verifica no terreno patológico a mesma distribuição de propriedades, comuns aos gêmeos provenientes de um único ovo". 205

O Brasil foi o líder na América Latina nas ciências biomédicas e sanitárias nas primeiras duas décadas do século XX, e o primeiro a estabelecer formalmente uma sociedade de eugenia. O termo em português "eugenia", distinto do termo espanhol "eugenesia", foi introduzido formalmente em uma tese da Faculdade de Medicina do Rio de Janeiro, defendida em 1914. A fundação da primeira sociedade de eugenia brasileira em 1918, com 140 membros (e uma na Argentina apenas alguns meses depois), foi apenas dez anos após a equivalente sociedade britânica e seis anos após a sociedade francesa. ${ }^{206}$ Fundada por iniciativa do jovem médico Renato Kehl, a Sociedade Eugênica de São Paulo teve como primeiro presidente Arnaldo Vieira de Carvalho, diretor da Faculdade de Medicina de São Paulo, e entre seus membros mais ilustres o diretor do Instituto Butantã Vital Brasil, o microbiologista do Instituto Oswaldo Cruz do Rio de Janeiro Artur Neiva, que havia chegado a São Paulo para chefiar a remodelação dos serviços sanitários, o médico Luis Pereira Barreto ${ }^{207}$ e ainda o jovem Fernando de Azevedo, que mais tarde seria uma importante figura nos rumos da educação pública do país. Apesar de

\footnotetext{
${ }^{205}$ BAPTISTA, Vicente. "Relatório apresentado ao Diretor Geral da Assistencia a Psicopatas". In: Pediatria Practica. Revista Mensal de Clinica Infantil e Puericultura. v.IV.janeiro e fevereiro de 1933. p.385.

${ }^{206}$ Conforme pesquisa realizada por STEPAN, N. The hour of eugenics, 1991. A Argentina, apesar de ser considerado o país mais avançado e rico na América Latina nos anos 20 e 30 do século XX, apresentava uma composição racial bastante distinta do Brasil, não havendo portanto a questão da "identidade racial do povo" por parte das elites.

${ }^{207}$ Pereira Barreto teria publicado em 1874 o primeiro tratado brasileiro escrito segundo o ponto de vista do positivismo sistematizado, As três filosofias. Conforme SKIDMORE, T. E. Preto no branco. Raça e nacionalidade no pensamento brasileiro, 1989, p.27.
} 
tantos cientistas notáveis, a Sociedade não tinha como objetivo realizar pesquisas, mas sim introduzir o Brasil na nova linguagem da eugenia. ${ }^{208}$

Na segunda década do século XX a eugenia aparece como um novo tipo de higiene social, e não pode ser considerada de forma monolítica ou mesmo como um corpo teórico homogêneo. Podemos entender essa presença da eugenia como a culminação de um longo projeto intelectual iniciado no século anterior, no qual a vida humana foi interpretada como sendo resultado de leis biológicas naturais. Francis Galton escreveu Hereditary Genius em 1865, texto fundador da eugenia, quatro anos após ter lido The origin of Species.

Galton assim definiria eugenia em uma palestra apresentada em 1904: "Eugenia é a ciência que lida com todas as influências que melhoram as qualidades inatas de uma raça; e também com aquelas que desenvolvem-nas na direção de uma vantagem menor [Eugenics is the science which deals with all influences that improve the inborn qualities of a race; also with those that develop them to the unmost advantage]". ${ }^{209}$ Enfatizava-se assim a idéia de que "a boa ou má qualidade do caráter não é absoluta, mas relativa em relação à atual forma da civilização [The goodness or badness of character is not absolute, but relative to the current form of civilisation]". Assim, o objetivo da eugenia segundo Galton seria "representar cada classe ou segmento por seu melhor espécime [to represent each class or sect by its best specimens]". Escolher os melhores implica apontar os piores. Foi assim que na década de 20 muitos eugenistas mudaram sua atenção da eugenia positiva

\footnotetext{
${ }^{208}$ A Sociedade seria formalmente encerrada em 1919, com a morte de Arnaldo Vieira de Carvalho e ida de Renato Kehl para a capital federal. Apesar de não ser criada na capital uma nova Sociedade, em 1922 foi fundada no Rio de Janeiro a Liga de Higiene Mental, que revelava uma psiquiatria eugenicamente orientada. Conforme STEPAN, N. The hour of eugenics, 1991

${ }^{209}$ Galton, Francis. Essays in eugenics, [1869] 1909. Capítulo intitulado "Eugenics: its definition, scope and aims", lido em 1904 conforme nota.
} 
imaginada por Galton, para uma eugenia negativa que objetivava prevenir a reprodução de indesejados, entre eles os pequenos psicopatas.

É com essa visão que Vicente Baptista assume a direção da secção de menores no Hospital de Juquery como psycho-pediatra. Com a inauguração do pavilhão-escola, as crianças foram divididas em dois grupos: "ineducáveis" e “educáveis". Para aqueles considerados "ineducáveis" só restava o pavilhão-asilo, e para os "educáveis" o pavilhão-escola. Segundo a descrição de Baptista, entre os educáveis estavam os "débeis mentais e anômalos com perturbações da moral e do caráter". Os ineducáveis seriam "idiotas de todos os gêneros, imbecis, epilépticos em marcha para estado demencial, pos-encefalíticos graves". Em sua descrição, o novo diretor relatava que "quase $50 \%$ dos menores são absolutamente imundos; os demais são pelo menos sujos e nenhum é amigo franco da higiene". ${ }^{210}$

Vale ressaltar que em 1928 Ernani Lopes - que tornar-se-ia presidente da Liga de Higiene Mental um ano depois, mesmo ano do Primeiro Congresso Brasileiro de Eugenia - apresenta um trabalho na Primeira Conferência Latinoamericana de neurologia, psiquiatria e medicina legal intitulado "Das Psychoses infantis e especialmente da paralysia geral infantil". O médico comenta a afirmação de Esquirol, de que "a infância está ao abrigo da loucura, exceto se a criança trouxer, ao nascer, algum vício de conformação, ou, por efeito de convulsões, for levada à imbecilidade ou idiotia" ${ }^{211}$ Segundo o autor, as estatísticas concluem que excluídas as "anomalias psychicas congênitas" - somente uma em 70.685 crianças

\footnotetext{
${ }^{210}$ BAPTISTA, Vicente. Relatório apresentado pelo dr. Vicente Baptista á directoria do Hospital de Juquery. In: Pediatria Practica. Revista Mensal de Clinica Infantil e Puericultura. V.3. janeiro de 1931. p.205.

211 LOPES, Ernani. Das psychoses infantis e especialmente da paralysia geral infantil. In: Actas de la Primeira Conferencia Latino Americana de Neurologia, Psiquiatria e Medicina Legal, 1928, pp.442-469.
} 
sofre de doença mental. Segundo Ernani, as estatísticas concernentes à infância deveriam estar bem abaixo da realidade do que as referentes àquelas vida adulta. Deve-se observar aqui as estatísticas indicadas no Boletim Trimestral de Estatística Demographo-Sanitária do Estado de São Paulo, publicadas para o ano de 1918. Nesse Relatório, em que não aparece a mortalidade por idade, mas sim o total por causa-morte, as "afeccções do systema nervoso" aparecem com índice superior à tuberculose, por exemplo. ${ }^{212}$

Ernani não se referia a manifestações que ele nomeava como sendo esquisitice, excentricidade, falta de educação, ou mesmo "criancice". Falava de casos internáveis, isto é, de "loucura infantil". Segundo ele, nem todos os doentes eram levados ao manicômio, isolando-os em geral no próprio domicílio, dada a “facilidade de dominar". É bom lembrar que infância era entendida, conforme delimitação de Afranio Peixoto, até 15 anos de idade, ou seja, "o período para o qual ainda não se pronunciou a puberdade”. O médico se pergunta por que a estatística dos casos de psicose infantil permanecia reduzida: "o certo é que a raridade das psicoses infantis se prende sobretudo à circunstância de que a luta pela vida, com as suas múltiplas repercussões sobre a esfera emotiva, não se faz ainda sentir sobre as crianças. Ao contrário, como todos sabem, a regra é que o afeto da família, ou o simples espírito humanitário dos cuidadores procurem preserva-las de toda contrariedade e desprazer". E concluía que, na clínica preocupada com diagnósticos precoces, já não satisfazia aos especialistas o mero estudo das psicoses

\footnotetext{
${ }^{212}$ BOLETIM Trimestral de Estatistica Demographo-Sanitaria do Estado de S.Paulo. Anno XXV, n.1/2/3/4, 1918. Diario Oficial. Directoria do Serviço Sanitario do Estado de S. Paulo.
} 
da infância, e sim de compreender e surpreender na infância certas psicoses do adulto. É o domínio da profilaxia mental.

\section{Prophylaxia e Estatística}

Segundo relatórios oficiais, a mortalidade infantil em São Paulo ascendia na década de 20. Na capital, a cada mil nascimentos 179,2 bebês morriam até o primeiro ano de vida. Na capital do país, o índice era semelhante: 170,82 . De 0 a 1 mês, atingia $8,45 \%$ da mortalidade geral e de 1 mês a um ano chegava a $25,53 \%$ da mortalidade geral. ${ }^{213} \mathrm{Na}$ cidade americana de Pittsburg, por exemplo, o ano de 1920 assinalaria um coeficiente de 24,8; Montevideo, 11,42; Assunção, 150,67. Segundo os técnicos da saúde pública do estado, se não fosse a "excelente" natalidade, o aumento da população dependeria apenas da corrente imigratória.

"A pobreza dos progenitores contribui largamente para a mortalidade da prole (...) Um exemplo bem frisante da relação existente entre os recursos paternos e a mortalidade infantil está no maior coeficiente de mortalidade entre crianças que vivem no seio de famílias que apenas dispõem de um quarto e as que podem dispor de maior número de aposentos", conclui Paula Souza como Director Geral do Serviço Sanitário do Estado de São Paulo. ${ }^{214}$ Diarréia e enterite aparecem como as responsáveis por quase $50 \%$ das mortes até um ano de vida. $\mathrm{O}$ item vago

${ }^{213}$ PAULA SOUZA, G. H. Algumas considerações sobre a mortalidade infantil em São Paulo. Faculdade de Medicina e Cirurgia de S. Paulo. Instituto de Hygiene. Boletim 18. Memoria escripta pelo dr. G. H. Paula Souza, Director Geral do Serviço Sanitario do Estado de S.Paulo, lida no $1^{\mathrm{o}}$ Congresso de Hygiene reunido no Rio de Janeiro, em 1 de outubro de 1923.

${ }^{214}$ Após estudos em Zurique, Paula Souza fora o primeiro diretor da Escola Politécnica criada em São Paulo em 1893. 
"debilidade congênita" é responsável por $17 \%$ das crianças mortas. A quase totalidade dessas mortes poderia estar relacionada com a alimentação artificial, consequência de mães obrigadas à separação prematura dos filhos para ingresso no mercado de trabalho.

Com 80 contos anuais destinados à capital, o Serviço Sanitário do Estado não foi capaz de reduzir a mortalidade infantil entre 1909 e a data do Relatório, o ano de 1923. A constatação de que parte da verba era direcionada para crianças doentes $e$ anormais faz com que o Diretor acentue a necessidade do atendimento a crianças sãs e normais, como forma de reduzir a assustadora mortalidade por meio de procedimentos mais direcionados a uma certa idéia de profilaxia, para a qual reivindica-se a criação de uma Delegacia de Prophylaxia Geral. Tal Delegacia deveria fornecer todos os elementos necessários para o estudo da epidemiologia, em colaboração com a Secção de Estatística Demographo-Sanitária. Apesar das bases do aparelhamento sanitário geral terem sido lançadas logo no início da República, ainda no final do século, com a criação do Instituto Bacteriológico e Vacinogênico (1892) e a divisão do estado por distritos sanitários cada um com seu respectivo diretor, São Paulo não contava com uma Faculdade de Medicina até 1912, quando os estudantes iam até o Rio de Janeiro ou Salvador para cumprir sua formação. ${ }^{215}$

Segundo Paula Souza, "a necessidade cada vez mais imperiosa dos dados estatísticos, para conhecer os fenômenos sociais" passava a representar então o "índice de inteligência de uma administração", conclui ele. Diz ainda: "Administrar sem estatísticas é agir às cegas, é se deixar conduzir pela fantasia perigosa e estéril

\footnotetext{
${ }^{215}$ Sobre o Instituto Bacteriológico ver STEPAN, N. Beginnings of brazilian science, 1981. Em 1925, o Instituto falhou em ser considerado um centro de medicina experimental e foi oficialmente fechado.
} 
de agir sobre o meio com inconsciência do meio". Os "problemas étnicos emergentes" em São Paulo estavam, segundo Paula Souza, diretamente relacionados a maior natalidade entre casais estrangeiros, "donde se vê claramente a influência ativa que nos vai modificando o tipo rácico". ${ }^{216}$ Nesse projeto contábil foi formalizado contrato com a Tabulating Machine Co, e instaladas no ano de 1923 as máquinas utilizadas no último recenseamento da República. As máquinas "Hollerith" eram de quatro tipos: perfuradoras simples e múltiplas, conferidoras, separadoras e tabuladoras. Cada funcionário passou a produzir cerca de 500 cartões perfurados por dia. Havia apenas dois impedimentos ao progresso anunciado pela estatística: em primeiro lugar, o falseamento dos dados, com a prática de consultas médicas em farmácias, "verdadeira vergonha para o conceito de civilização no tocante às práticas médicas" e em segundo lugar, a habilitação legal de profissionais estrangeiros, considerados pouco cooperativos com os problemas sanitários do país: "poucos são os de real valor, profissional ou moral mesmo, que imigram para o nosso meio (...) a grande maioria não se preocupa sequer com nossas leis sanitárias, ou se as procuram saber, é só com o intuito de nos iludir mais seguramente", alerta Paula Souza.

Recreio e arame farpado

${ }^{216}$ PAULA SOUZA, G. H. Serviço de Estatistica sanitaria. Faculdade de Medicina e Cirurgia de S. Paulo. Instituto de Hygiene. Boletim 19, 1924. 
Tais revoluções na estatística sanitária não haviam chegado ao Hospital de Juquery. Em 1931 o antigo pavilhão agora denominado pavilhão-asilo foi reformado com o objetivo de sanar alguns problemas existentes, como a falta de água. Era uma construção em tijolos de dois pisos, com lotação para 40 meninos, alojados em um único dormitório geral no andar superior. O quarto da encarregada também ficava no andar superior, além de um pequena enfermaria. No térreo estavam localizadas a sala para exames, o refeitório e o quarto das guardas. Em uma das faces do pavilhão, havia um "páteo de recreio", fechado por cerca de arame. Afastado a cerca de cem metros do pavilhão-asilo ficava o prédio da escola, projeto e construção do engenheiro do Hospital, Ralph Pompêo de Camargo. Era também uma construção de tijolos em dois pavimentos, com lotação para 40 crianças. Havia, contudo diferenças fundamentais em relação ao pavilhão-asilo, pois a construção tinha sido projetada especialmente para abrigar as instalações de uma escolahospital, no dizer do diretor da Secção de menores. À frente do prédio havia um pequeno jardim, e a parte dos fundos foi reservada para o pátio de recreio, com cerca de 50x30. A cerca de arame, entretanto, permanece.

As instalações da escola propriamente dita ficavam no andar térreo, que era dividido em duas seções: uma, com sala de trabalhos manuais e sala do médico, enfermarias de urgência, museu escolar e laboratório psico-pedagógico. A outra seção incluía a sala de aulas (com carteiras individuais) e sala do professor. No térreo havia ainda uma copa e o refeitório. No andar superior ficavam os dois dormitórios (grande e pequeno) e uma enfermaria. Havia ainda os dormitórios do pessoal de serviço. As crianças "entradas" na instituição passavam, durante as 
primeiras 24 horas, por um "exame" realizado pelo médico de plantão. A seguir a criança era encaminhada ao pavilhão-asilo, onde permanecia até que se completasse sua observação e se decidisse sobre seu destino: asilo ou escola. As consequências dessa decisão, escola ou asilo, eram claras inclusive a algumas crianças, para as quais "constitui castigo a simples ameaça de transferência para outros pavilhões". ${ }^{217}$ O exame psicológico por meio de testes é mencionado a partir da escala BinetSimon-Burt, adaptada por Isaias Alves. ${ }^{218} \mathrm{O}$ próprio Binet, no entanto, seria cético em relação ao tratamento médico-pedagógico pregado pelos alienistas em asilos, propondo uma divisão entre anormaux d'asile e anormaux d'école. ${ }^{219}$

O "diagnóstico", entretanto, era dificultado pelo fato de cerca de $80 \%$ dos internados chegarem ao hospital sem nenhum dado anamnésico. Para sanar este problema, assim que assumiu a Seção o diretor resolveu enviar o que chamava de "Interrogatório", acompanhado por carta-circular, aos responsáveis pelas crianças internadas. Na carta era realçada a importância das informações para o eventual êxito do tratamento, salientando-se que se tratava de uma medida científica e não meramente burocrática. Não houve mais menção a este tipo de procedimento em outros relatórios.

A internação de uma criança poderia se dar em várias situações. Por exemplo, o caso de um menino de Campinas que foi internado "porque transformara a casa paterna numa sucursal do inferno. Fujão e brigão, dissimulava e

\footnotetext{
${ }^{217}$ BAPTISTA, Vicente. Relatório apresentado por dr. Vicente Baptista á directoria do Hospital de Juquery. In: Revista Mensal de Clinica Infantil e Puericultura. v.3.janeiro de 1931. p.296.

${ }^{218}$ SILVA, Pedro. Assistencia aos menores anormaes. Subsidios para o seu estudo em S. Paulo. Dissertação apresentada à Cadeira de Clinica Psychiatrica e Neuriatrica (Trabalho do Hospital de Juquery), 1931, p.35.

219 PINELL, Patrice. "L'invention de l'echelle métrique de l'intelligence". Actes de la recherche en sciences sociales 108, juin 1995, pp.18-35.
} 
reincidia. Eram pois típicas anomalias de carater" ${ }^{220}$ Havia ainda os casos de crianças que morriam em situações que revelavam absoluta falta de cuidados médicos, apesar de internos em um hospital: é o caso de um jovem "perverso e instável, com sequelas de encefalite epidêmica (...) Menino robusto, que resistia aos surtos infecciosos que se declaravam no pavilhão, que jamais se queixou de qualquer perturbação, que ao exame objetivo nada apresentava de anormal de saúde física, adoece subitamente e falece antes que se firme diagnostico. A autopsia revelou tratar-se da perfuração de uma antiga ulcera do intestino delgado". ${ }^{221}$

O trânsito de crianças entre o pavilhão-asilo e o pavilhão-escola mostrou-se intenso nos três primeiros anos de funcionamento da Seç̧ão. Das 38 crianças internadas no pavilhão-asilo em 1930, 29 foram encaminhadas para o pavilhãoescola. No ano seguinte, o relatório do professor indicava que sete foram "inaproveitáveis", e mais quatro foram removidos por vários motivos como "excesso de idade, estado mental, indisciplina". Entraram porém mais oito crianças para a escola, das quais quatro "ficaram inaproveitadas", ou seja, foram "removidas" para o pavilhão-asilo. Em seu primeiro relatório como diretor da seção de menores, Baptista conta que, no início de 1930, havia no pavilhão-asilo 38 menores, para uma lotação prevista de 40 crianças. A Escola, nesse mesmo período, recebia 37 crianças, das quais dez vindas do Instituto Disciplinar. ${ }^{222}$

\footnotetext{
${ }^{220}$ BAPTISTA, Vicente. "Relatório apresentado ao Diretor Geral da Assistencia a Psicopatas". In: Pediatria Practica. Revista Mensal de Clinica Infantil e Puericultura. v.IV.janeiro e fevereiro de 1933. p.386.

${ }^{221}$ BAPTISTA, Vicente. Escola Pacheco e Silva. Relatório apresentado ao Dr. Diretor do Hospital de Juquerí. In: Pediatria Pratica. V.IV. janeiro/fevereiro, 1932. pp.179-185. p.181.

${ }^{222}$ Conforme observações de prontuários publicados em SILVA, Pedro. Assistencia aos menores anormaes. Subsidios para o seu estudo em S. Paulo. Dissertação apresentada à Cadeira de Clinica Psychiatrica e Neuriatrica (Trabalho do Hospital de Juquery), 1931, p.37-51.
} 
Havia ainda os relatos de "evasão", sinônimo oficial para fuga, e casos em que as próprias famílias resolviam retirar as crianças, independentemente da alta médica. Esses, contudo, eram relativamente esparsos, pelo menos nos dados oficiais: em 1930, apenas uma criança foi retirada pela família, e fugiram dois. Dois anos depois, sete famílias retiraram seus filhos do pavilhão-escola e três do pavilhão-asilo, e oficialmente não houve fugas. Nos três primeiros anos da década de 30, não houve alta para nenhuma criança. Quando a Seção foi criada, ao completar 17 anos, as crianças deveriam ser "removidas" para outros pavilhões. A remoção para outros pavilhões também poderia se dar por motivos de indisciplina. Em 1932, por exemplo, 3 meninos "extremamente agressivos, indisciplinadíssimos" foram transferidos para os pavilhões dos homens. Os supostos casos de epilepsia também eram encarados como impeditivos para a frequência à escola. No pavilhãoasilo, por exemplo havia em 1930 dez crianças assim diagnosticadas. Segundo as concepções medico-pedagógicas do diretor, o ensino não seria indicado para estas crianças: "todos têm apresentado uma queda lenta, porem progressiva, da inteligência, havendo alguns já em estado de idiotia. Essa verificação vem confirmar o juízo pessimista de Binet quanto ao futuro da maioria dos epiléticos. Dai ainda a minha dúvida quanto aos resultados finais do corretivo-pedagógico; se não resultará um inútil desperdício de tempo e dinheiro". ${ }^{223}$ Havia porém algumas crianças com este diagnóstico na escola, que apresentavam "crises espaçadas às vezes de mais de uma semana". Estas crianças transitavam entre os dois pavilhões conforme a frequência de crises.

\footnotetext{
${ }^{223}$ BAPTISTA, Vicente. A Escola Pacheco e Silva. Relatório apresentado pelo dr. Vicente Baptista á directoria do Hospital de Juquery. In: Pediatria Pratica. V.III. janeiro, 1931. pp.203-207. p.205.
} 
Segundo o diretor Vicente Baptista, no programa educacional os exercícios deveriam ocupar o lugar principal: "o trabalho manual com os jogos educativos, a modelagem, a cartonagem, a ensartagem e outras pequenas ocupações. Seguem a isso as lições de coisas, em classe, obedecendo o método natural, em excursões campestres, estimulando o hábito de observação, e a ginástica, excitando diretamente a atividade física e indiretamente a atividade mental (...) Para eles a instrução tem valor muito relativo do ponto de vista do desenvolvimento intelectual e da utilização social. O ensino das disciplinas intelectuais - linguagem oral e escrita, princípios cívicos etc - é ministrado segundo os métodos correntes na instrução de anormais, que visam mormente a educação dos sentidos, da atenção, da vontade, em suma, que contribuam para aumentar o mais possível o valor social do educando. Isso significa um programa eminentemente utilitário. Aos mais prendados ensina-se como ganhar a própria vida, estimulando suas aptidões utilizando o que de dispõem de força intelectual, orientando o aprendizado para fins práticos, como os de ofícios ligeiros". ${ }^{224}$

Os planos do então diretor foram cientificamente corroborados por uma tese apresentada residente na seção de menores Pedro Silva, intitulada Assistência aos menores anormaes, defendida junto à cadeira de Clínica Psychiatrica e Neuriatria do Hospital de Juquery. ${ }^{225}$ Neste trabalho, o autor propõe diretrizes para a seleção, distribuição e tratamento medico-pedagógico dos "menores anormaes" segundo os tipos de "defeitos psico-morais, que poderiam ser "anomalias intelectuais

\footnotetext{
${ }^{224}$ BAPTISTA, Vicente. "Secção de Menores Anormais do Hospital Central de Juquery. Serviço de Assistência a psicopatas". In: Arquivos do Serviço de Assistência a Psicopatas do Estado de São Paulo. Ano III. $1^{\mathrm{O}}$. e $2^{\mathrm{O}}$. trimestres, 1938. pp.251-258. p. 256.

${ }^{225}$ SILVA, Pedro. Assistencia aos menores anormaes. Subsidios para o seu estudo em S. Paulo. Dissertação apresentada à Cadeira de Clinica Psychiatrica e Neuriatrica (Trabalho do Hospital de Juquery), 1931.
} 
propriamente ditas, anomalias de caráter e anomalias morais". O último capítulo do trabalho dedica-se a tecer comentários da predominância do fator hereditário na geração dos "menores anormais", colocando o alcoolismo dos pais como seu fator preponderante. Sem apresentar estatísticas, o autor alerta para o aumento de ano para ano do número de menores criminosos no mundo, sendo portanto um problema que exige um complexo aparelhamento do Estado para tratar de crianças em idades diversas e condições físicas e psicológicas também diversas. Para o autor, muitas vezes o anormal já é consequência do meio familiar - pais tarados, alcoolismo e miséria - incapazes para preparar o menor para qualquer atividade profissional. Para prevenir a delinquência, visitadoras deveriam apontar as primeiras perturbações do caráter ou da moral que, em geral, passam desapercebidas ao leigo, mas já indício de uma tendência ao desequilíbrio mental e à delinquência. Este "serviço social" 226 seria primordial deveria fornecer informações úteis a partir de interrogatório apurado da família e dados colhidos na escola. O diagnóstico social da delinquência deveria seguir regras, como aquelas existentes para o diagnóstico médico, pois causas patológicas e sociais se associavam na produção da delinquência na criança.

Em 1930, a institucionalização da infância criminalizada na cidade de São Paulo contava com o Abrigo de Menores, o Instituto Disciplinar do Belemzinho, o Instituto Disciplinar de Mogy-Mirim, patronatos agrícolas e a seç̧ão de menores do Hospital de Juquery, com a escola Pacheco e Silva. Conforme avaliação de Pedro

\footnotetext{
${ }^{226} \mathrm{Em} 1927$ o aparelhamento escolar do Estado passou a ter um médico psiquiatra, que lhe foi definitivamente incorporado por decreto em 1929. O trabalho foi ampliado em 1938, com a criação, junto ao serviço de Saúde Escolar da respectiva Seç̧ão de Higiene Mental, sob a direção de Durval Marcondes. $\mathrm{Na}$ coletânea, há um interessante artigo sobre a "função da psicologista" na clínica de orientação infantil. Conforme MARCONDES, Durval e colaboradores. Noções gerais de higiene mental da criança, 1946.
} 
Silva, no próprio Abrigo de Menores, destinado a recolher meninos sob a guarda do Juízo de Menores, as crianças não eram assistidas “de forma científica”, pois não havia a "indispensável separação entre os verdadeiros e os falsos anormais".227 Falsos anormais seriam aquelas crianças vítimas do meio social. Segundo o médico, apenas no Juquery havia assistência adequada aos menores anormais, projeto que deveria ser ampliado pelos poderes públicos. Segundo cálculo do Juiz de Menores citado pelo autor, havia no Estado de São Paulo cerca de 20 mil crianças necessitando atendimento, muitos deles pelas ruas e cadeias.

Um elemento forte do argumento médico afirmava as razões de ordem econômica que se impunham. Era preciso tornar todas as inteligências aproveitáveis, todos os cérebros, desde os mais obscuros, deveriam ser postos a serviço da pátria.

Já se configurava um acordo entre médicos, criminologistas e pensadores sociais de que a criança culpada por um delito não deveria ser condenada, mas sim "reeducada" sob o controle do Estado. Nessa tarefa, cabia ao médico tornar aproveitáveis as crianças, elevando-se o nível intelectual e mental, averiguar a etiologia das anomalias adquiridas e evitar sua progressão no indivíduo e eventualmente seu contágio a outro. O estudo científico das causas e da evolução das afecções congênitas e adquiridas, capazes de determinar anomalias psíquicas, teria a vantagem de melhorar os meios de combate e profilaxia, reduzindo no futuro sua frequência.

\footnotetext{
${ }^{227}$ Conforme análise realizada por SILVA, Pedro. Assistencia aos menores anormaes. Subsidios para o seu estudo em S. Paulo. Dissertação apresentada à Cadeira de Clinica Psychiatrica e Neuriatrica (Trabalho do Hospital de Juquery), 1931, p.9 e seguintes.
} 
Mas essa profilaxia deveria levar em conta que o anormal não se parece nada com o normal lento, ou estabilizado no momento de sua evolução. O atraso em geral não é apenas uma lentidão na evolução, para o que bastaria empregar os mesmos métodos dos normais. Não é apenas inferior em grau, é uma mentalidade à parte. Sua evolução não foi atrasada de uma maneira global, mas entravada em determinada fase, para depois prosseguir em outras direções. O ensino primário deveria ser libertado desse peso morto representado pelos anormais, cuja irritabilidade e instabilidade são motivo de infração e indisciplina. Para os anormais, a instrução obrigatória seria uma preciosa perda de tempo. Afastados da classe comum, seu rendimento será superior porque o professor trataria com uma classe homogênea. Médicos, psychólogos - pela primeira vez - educadores e magistrados fazem agora dos anormais uma vigilância especial, que continuará porteriormente sob patronagem.

Nas novas instituições propostas torna-se fundamental a colaboração entre o psiquiatra e o psicólogo na orientação de cada menor de acordo com suas tendências, caráter e reações mórbidas. São Paulo já poderia ser considerada uma cidade cosmopolita. Este "verdadeiro cadinho de raças diversas que para lá transportaram credos políticos e sociais" torna-se o local que favorece os menores anormais. Raça aqui passa a ser entendida como um termo predominantemente utilizado menos no sentido estritamente biológico do que como sinal que 
identificava populações que supostamente carregavam uma unidade física e cultural ou mesmo econômica. ${ }^{228}$

À diversidade da infância anormal deveria corresponder o funcionamento harmônico de dois sistemas: uma assistência interna, que considerava-se realizada em parte na secção de menores do Hospital de Juquery; ao lado de uma assistência aberta, que estava em cogitação nos planos de Lourenço Filho, então diretor geral da Instrucção Pública. Os modelos estudados eram aqueles praticados na Alemanha [Heil-paedagogische Beratungstellen, postos de pedagogia curativa] e nos Estados Unidos [Child Guidance Clinics, que constituem uma das bases da higiene mental americana], além da assistência social na França, anexa à clínica de neuropsiquiatria infantil, que apurava as primeiras perturbações do caráter da criança que poderiam traduzir tendências futuras ao desequilíbrio mental ou delinquência. $\mathrm{O}$ modelo alemão, entretanto parecia ser o preferido, como a divisão em departamentos orientados por psiquiatras na cidade de Hamburgo, que funcionavam como postos avançados de observação ${ }^{229}$ classificando os menores em diferentes categorias e procedendo ao exame neuro-psiquiátrico e psicológico. O trabalho inicial desses postos de observação orientaria a direção da pedagogia curativa e se estenderia até classes anexas às escolas comuns, por orientação de Lourenço Filho, para os casos em que a vigilância atenta poderia manter o menor no meio habitual.

\footnotetext{
${ }^{228}$ Sobre representações raciais e imigração ver RAMOS, Jair de Souza, "Dos males que vêm com o sangue: as representações raciais e a categoria do imigrante indesejável nas concepções sobre imigração da década de 20", 1996.

${ }^{229}$ Conforme pesquisa realizada por Lifton, em 1936 têm início as discussões entre oficiais nazistas sobre a eliminação de crianças idiotas ou consideradas doentes mentais. A partir de filmagens nos asilos para demonstrar a miséria de suas vidas, a disseminação dessas cenas incentivou o aumento de pedidos de "morte piedosa", que eram encaminhadas diretamente ao Führer. Pouco a pouco foram sendo aumentadas as autorizações, primeiro recém-nascidos, depois até 3 ou 4 anos, depois os mais velhos. Foi então criado o Comitê do Reich para Registro Científico de Doenças Congênitas e Hereditárias, que levou a cabo os planos de eliminação de crianças consideradas doentes mentais internadas em instituições para jovens delinquentes. Conforme LIFTON, Robert Jay. The nazi doctors, 1986, capítulo sobre "Eutanásia".
} 
Para os casos em que a separação do menor do ambiente se tornasse necessária, o internato compreenderia três formações distintas: asilo para os casos crônicos incuráveis, escola médico-pedagógica para os educáveis; colônias agrícolas para os suscetíveis de aprender ofícios.

A seleção realizada nos postos de observação deveria operar uma distinção entre os anormais por causa patológica daqueles de causa social. Os defeitos psicomorais poderiam apresentar-se sobre três formas: anomalias intelectuais, anomalias do caráter e anomalias morais. As anomalias intelectuais consistiam em uma parada mais ou menos marcada das faculdades mentais (atenção, memória, imaginação, associação de idéias). Seguia-se aí a classificação por intensidade proposta por Bourneville: idiotia, imbecilidade, atraso ou debilidade mental. As anomalias de caráter, por sua vez, abrangeriam várias formas: instabilidade psico-motora, astenia infantil, hiper-emotividade e anomalias dos deprimidos, periódicos e paranóicos, casos encontrados principalmente na adolescência. Entre as anomalias morais figuram as psico-morais, bastante diversas: são considerados os menores difíceis, indisciplinados, mentirosos e viciosos.

Entre os defeitos morais infantis não se poderia confundir duas grandes classes: perversos ou viciosos e pervertidos ou viciados. Os perversos poderiam ser instáveis morais ou indiferentes morais, perversos ocasionais, perversos ativos ou definitivos e perversos intermitentes. Entre os pervertidos, haveria aqueles apenas por influência do meio, os pervertidos com debilidade mental e os pervertidos com anomalias do caráter. Finalmente, havia ainda as anomalias combinadas, quando as anomalias mentais e morais se apresentariam associadas. Tal gama de classificações 
não era razão para que os médicos acrescentassem às observações uma sem-número de termos: briguento, destruidor, hipócrita, agressivo, quieto, nervoso, dócil, sugestionável, calmo, afetuoso, serviçal, raciocínio lento, memória má, tímido, instável, vadio, bons sentimentos éticos, obediente, sociável, rebelde, fujão, raciocínio pueril, analfabeto, raciocínio medíocre, bom caráter, boa conduta, raciocínio paupérrimo, percepção tarda, fisionomia aparvalhada, sexualmente invertido, pudor embotado, asseio precário, humor variável, simulador, estigmas de degeneração, violento, impulsivo, irritável, versátil em relação ao meio, vivaz, teimoso, destruidor, mentiroso, hipócrita, intrigante. Ainda sobre as famílias das crianças: mãe nervosa, péssimo ambiente, mãe sifilítica, primo epilético, pai alcoolista, primo e tio alienados, mãe casada em segundas núpcias, padrasto irascível, mãe neurastênica.

A definição de tratamento médico-pedagógico não dizia respeito a um só método aplicado sem distinção a essa ampla classificação. Tratava-se mais precisamente de uma organização médico-pedagógica que prescrevia métodos diversos para anomalias diversas. Quando se tratava de reprimir as perturbações morais parecia ser necessário lançar mão de outros recursos, mostrando-se quase sempre ineficaz o tratamento médico-pedagógico. Perturbações da inteligência e do caráter impediriam a criança de discernir o bem do mal, predispondo-a a certos atos anti-sociais. Tendo-se em vista uma criança perversa e ao mesmo tempo inteligente, o tratamento seria diverso daquele dos atrasados. A insociabilidade poderia estar relacionada com o período de puberdade, período acompanhado de fenômenos 
inquietantes, atos imorais, perversões sexuais, tanto mais alarmante quanto menos propício o ambiente em que vivessem tais menores.

Sendo assim, a opinião dos médicos sobre a questão da menoridade perante os códigos indicava a necessidade da distinção entre uma idade fisiológica e uma idade cronológica. Para o discurso médico, seria anti-científico basear-se na idade cronológica, pois somente pela idade fisiológica deveria ser dirigida a ação reeducativa, principalmente porque para certos menores, a intimidação é o único processo a utilizar, até a criação do hábito da boa ação: "Se o medo da punição não está constantemente presente ao seu espírito, eles apenas obedecem às suas impulsões e aos seus desejos", conclui Pedro Silva em sua tese.

Apesar de todas essas intenções reeducativas, a assistência aos anormais não deveria ser considerada apenas do ponto de vista pedagógico, uma vez que a instrução escolar não poderia ser critério do grau de adaptação social. A assistência deveria ser encarada como um problema social, e a educação entendida num sentido mais amplo: o de educação para o trabalho. Não bastaria dotar um menor de conhecimentos, deixando-o sem profissão e com um mínimo de aptidões morais. Para que os princípios de moralidade lançados na escola permanecessem ativos era fundamental que o anormal não ficasse desocupado, que adquirisse uma ocupação compatível com seu caráter e sua mentalidade. Após a saída da escola-hospital, a vigilância deveria ser muito mais prolongada, pois durante anos certos anormais psíquicos não passam de convalescentes. É por isso que nas fichas de observação do médico Pedro Silva aparece, ao lado do diagnóstico, a "vocação" de cada crianças, onde se lê: "trabalhos mecânicos", "artes gráficas" e "incerta". 
Sob esses pressupostos, o caráter "prático" do ensino proposto foi tornandose cada vez mais presente nas atividades da Escola. Preocupado com uma "educação técnica" das crianças, o vice-diretor do Hospital pretendia encaminhar para os trabalhos agrícolas, sob a fiscalização de monitores, "os menores com tendências à vida campestre". Pretendia-se também construir um galpão para oficinas de aprendizagem de carpintaria, marcenaria, selaria, sapataria, colchoaria, mecânica, que seria localizado na extremidade livre do páteo de recreio. As crianças entrariam assim nos programas de laborterapia do Hospital. 


\section{Hospital e prisão, escola e trabalho}

Diante de um novo objeto de ciência - a infância criminalizada - médicos e juristas recorreram a classificações para nomear aquilo que acreditavam ser o resultado fatal de descaminhos na evolução. Como vimos, a teoria da evolução pela seleção natural não se limitava à biologia - ela ratificava o triunfo da história sobre todas as ciências, embora "história" nesse sentido fosse normalmente entendida pelos contemporâneos como "progresso". Além disso, ao trazer o próprio homem para dentro do esquema da evolução biológica, abolia a linha divisória entre ciências naturais, humanas ou sociais. ${ }^{230}$

Apesar de haver um largo leque de opiniões sobre as causas da criminalidade, era acordo entre os homens de ciência que os criminosos eram condicionados anormalmente por fatores biológicos; e quanto mais precoce fosse o

${ }^{230}$ Conforme HOBSBAWM, E. A era do capital, 1997, p.359. 
crime, mais determinantes seriam esses fatores. Como em outros países, no Brasil os cientistas do social propuseram e implementaram instituições para as crianças criminalizadas, mas estiveram longe de um consenso sobre o que fazer com elas, ou mesmo de quem falavam.

A pesquisa aqui apresentada procurou mostrar que o sentido construído para o objeto "infância criminalizada" não é unívoco ao ser delineado nas sentenças jurídicas, nas medidas policiais, no diagnóstico psiquiátrico ou nos projetos pedagógicos. Procuramos descrever essa polissemia durante a Primeira República, apreender os interstícios que separam os discursos e apontar o jogo recíproco e múltiplo de categorias psicológicas nessa dispersão. A análise pretendeu assim indicar marcas da sedimentação de categorias psicológicas no discurso sobre a infância criminalizada. Ao descrever essa dispersão, procurou-se enfatizar fundamentalmente em que medida o discurso psicológico foi permeável a opções filosóficas ou "morais", e atravessado radicalmente pela prática política.

Não se trata de concluir aqui que, a partir das primeiras superfícies da emergência da infância criminalizada, em uma época determinada o delinquente precoce (cabe perguntar qual seria o momento de "maturidade" para a entrada no mundo do crime) foi "psicologizado" ou "patologizado". A formulação colocada por esta pesquisa inverte a questão, e propõe indagar a respeito dos efeitos da criminalização da infância sobre a constituição do campo da psicologia no Brasil. O que interessou enfatizar nessa pesquisa foi como a conduta transgressora de crianças tornou-se objeto para uma série de saberes, e em particular para determinado saber psicológico emergente, reconfigurando instâncias fronteiriças 
entre normalidade e anormalidade. Entende-se aqui saber como um conjunto de elementos formados por uma prática discursiva e indispensáveis à constituição de uma ciência, apesar de não se formalizarem necessariamente como científicos.

A pesquisa indicou que a formação desse saber psicológico entrou em cena quando se estabeleceu relação entre categorias penais e graus de desenvolvimento específicos atribuídos à infância. Tal relação já está estabelecida em Menores $e$ loucos em Direito Criminal (1884), em que Tobias Barreto apoia a psicologia criminal no fato de que o homem "normal", aquele que durante a infância passou por fases normais de desenvolvimento (aqui no sentido haeckeliano, da ontogênese que revive a filogênese), chegando a uma certa idade adquiriria a capacidade para reconhecer o valor jurídico de seus atos.

Ao eleger a teoria da recapitulação como chave para o entendimento da "evolução psíquica" na infância, Tobias questiona a noção nada "evolutiva" de discernimento presente no Código do Império, operando uma nova interpretação do crime praticado por crianças. A problemática assim colocada tornava necessário não apenas definir qual idade seria esta, ou seja, a partir de qual idade uma criança seria capaz de reconhecer o valor jurídico de seus atos, mas fundamentalmente se esta idade seria a mesma não importando quais fossem as condições em jogo. A idade cronológica não poderia mais ser considerada $\mathrm{o}$ fator determinante da imputabilidade, na medida em que a "cultura espiritual" apresentava aspectos heterogêneos (fato que, segundo ele, poderia ser observado também nos diversos povos espalhados pelo globo) dado o péssimo sistema de ensino do país. Tobias desmonta assim uma idéia anódina de "normalidade cronológica" que não 
considerava os efeitos de diferentes "níveis culturais" nas camadas da sociedade, condição que o Código do Império ignoraria.

As crianças, aqui já como "menores", estariam mais sujeitas a essa diferença provocada pelo desnível na "cultura espiritual", e portanto mais suscetíveis na determinação do certo e do errado. É fundamental lembrar que dados gerais sobre a instrução no país mostram que em 1872 (portanto poucos anos antes da publicação de Menores e loucos), entre os escravos, o índice de analfabetos atingia 99,9\% e entre a população livre aproximadamente $80 \%$, subindo para mais de $86 \%$ quando consideramos só mulheres. Somente $16,85 \%$ da população entre seis e quinze anos frequentavam escolas e havia apenas 12 mil alunos matriculados em colégios secundários. $^{231}$

Com essa primeira crítica ao discernimento iniciamos o percurso no território do saber psicológico sobre a infância criminalizada, ainda amarrado ao efeito moralizador objetivado pela escolarização oficial, que segundo Tobias falhava na tarefa de proporcionar o instrumental necessário para o exercício da vida social plena. Recusando o individualismo contido no evolucionismo spenceriano, e apontando falhas no corpo social - o péssimo sistema de ensino do país, por exemplo - que desqualificariam a sobrevivência do mais apto como lei, Tobias Barreto constrói sua crítica ao país dos bacharéis.

Nesse momento inaugural da República, quando se trata de infância criminalizada, "educação" é, por um lado, treinamento para trabalhos específicos, e por outro, espécie de tratamento moral que deveria retirar as crianças dos caminhos

${ }^{231}$ Conforme dados apresentados por FAUSTO, Boris. História do Brasil, 1996. 
desviados da má conduta. Se faltam braços no campo, é necessário despertar-lhes o gosto pelos trabalhos rurais, para restaurar o senso moral. Ler, escrever e contar não devem ofuscar o objetivo primordial, que é a salvação moral pelo trabalho. Quando se trata de tendências viciosas precoces, abrigar é eufemismo para detenção.

"Educar" é, nesse contexto, corrigir falhas herdadas, que aparecem nos vícios e na vagabundagem, prenúncios do crime. Contra a impulsividade e precocidade presentes na vida criminosa, o alvo passa a ser a criança "abandonada", entendida como aquela que vagueia pelas ruas como resultado da absoluta dissolução dos costumes nas famílias pobres, expostas à ociosidade e ao vício. Este abandono moral ao qual estão submetidos passa a ser encarado como o primeiro passo rumo à vida criminosa, após um estágio no mundo dos vícios, e exige a construção de um poderoso dique que possa represar tamanho descaminho na evolução. A ação preventiva apontava para o objetivo de transformar menores perigosos em homens úteis. A atuação do Estado era pensada a partir da premissa de que o binômio educação/trabalho deveria permitir a constituição de elementos produtivos, em um país ainda essencialmente agrícola e regionalizado.

Crianças em perigo moral, sob a escala classificatória abandonada-viciosadelinquente, não tinham lugar no precário sistema escolar oficial da recente república. Preocupado com uma fadiga intelectual imaginária, o discurso sobre a criança escolarizada entendia a surmenage como principal desvio a ser estudado, para o qual novos saberes emergiam em torno do cotidiano escolar. O prejuízo no sistema nervoso provocado pelo excesso de trabalho escolar não tem paralelo, 
porque excesso de trabalho não-intelectual é entendido no plano de um tratamento moralizador, e portanto restaurador da normalidade cerebral.

Doravante, a formação do saber psicológico sobre a infância criminalizada traça sua rota ao estabelecer uma relação entre critérios de restauração da normalidade e um sistema de punição e educabilidade existentes na lógica prisional. Ao entender que a partir dos nove anos de idade poderia ser questionado o discernimento de uma criança, o Código Penal republicano de 1890 repõe a infância em uma nova categoria jurídica. Por um lado, amplia-se o plano específico da infância, excluindo-a oficialmente das prisões adultas e criando-se consequentemente "prisões infantis". Por outro lado, a infância criminalizada emerge como alvo de uma ação direcionada por saberes que deveriam atuar diretamente nos males impostos pela herança fatal. Prisões infantis sim, mas levando-se em conta a maturidade mais "precoce" de raças inferiores, principalmente negros e índios. Linhas de desenvolvimento mental mais singelas, porém mais resistentes, ao contrário dos povos civilizados, exigem menos tempo de evolução, são mais rápidas, aceleram o senso moral em determinada direção. Porém, na "nova criminologia" a moralidade é situada em um plano específico, aquele que precede o da inteligência, elemento que portanto fica à deriva de um senso moral incerto. Tais crianças amadureceriam precocemente, e portanto seriam capazes de discernir o certo do errado, mas por outro lado corriam o risco de amadurecerem sem rumo, tomadas por tendências ancestrais resistentes ao processo civilizatório mais fino. A prisão infantil deveria ser um asilo, um lugar de tratamento racial - nos moldes da nova ciência criminal - e não mais 
estabelecimentos agrícolas, que insistiam no trabalho rural como desmonte do elo ociosidade-vício. Uma instituição que se revelasse ao mesmo tempo asilo e prisão permitiria a atuação severa contra o peso da hereditariedade, uma vez que a educação passa a ser coadjuvante sem forças como vetor constitutivo do caráter.

O processo de punição entendido agora como tratamento colocaria assim a organização psicofisiológica inferior em luta com tendências superiores, de adaptação mais complexa, porém menos fortes por serem mais recentes. Sob o princípio da modificabilidade, Nina Rodrigues reafirma o preceito comteano de que os fenômenos mais simples seriam também os menos modificáveis, os mais resistentes, os mais atávicos. Quanto mais atávico se julgar um crime - e o crime cometido por crianças era o exemplo mais cruel do atavismo, até o limite do criminoso nato - menor a possibilidade de regeneração. Hospício de criminosos ou prisão de loucos, a lógica exigia uma instituição que retirasse a "chusma de degenerados" dos hospícios e criasse um asilo especial de criminosos que nasciam como tal, ou desde a infância mostrassem a tara que os acompanhava durante toda a vida. A lógica prisional passa a organizar a restauração da normalidade.

O corolário dessa nova configuração está em que, na São Paulo do início do século, tanto o Instituto Disciplinar como a Colônia Correcional tinham como meio de restauração da normalidade a "educação pelo trabalho" no sentido de "educação para o trabalho". À escola premonitória, aquela que adverte, que anuncia por um lado a punição e por outro o mal que se suspeita maior a cada ano de vida, cabia ministrar "educação física, profissional e moral" aos menores recolhidos. Educação, nesse contexto, era tratamento psicofísico, uma vez que visava modificar a 
influência da hereditariedade psíquica e moral que marcava a criança. A modificabilidade, entretanto, dependia do grau de inteligência e perversidade de cada recolhido. Nessa visão, a escola - ou melhor, a escolarização - seria uma faca de dois gumes: quando não constituísse freio moral, seria uma espécie de estimulante intelectual, um "aperitivo mental", conforme termo da época que parece fazer leve referência aos perigos morais do alcoolismo. O critério de ineducabilidade, no sentido de recusa da aprendizagem das regras do social, passou a marcar o território da infância criminalizada. Criado esse novo registro, passou-se a legislar sob seu plano, julgar e punir a impossibilidade de correção. Escola-prisão para a criança viciosa, irreparável em sua perversidade.

Sob a psicologia classificatória da ortopedia moral, perversidade e inteligência mantêm-se no mesmo arco. A perversão dos instintos - que levaria ao crime precoce - passaria a ser definida como uma das características da anormalidade de inteligência, entendida como a parada do desenvolvimento das faculdades intelectuais, morais e afetivas. Se há pouco mais de uma década a inteligência permanecia em um plano auxiliar, enquanto o caráter moral marca o atávico da raça inferior, doravante o argumento torna-se mais permeável ao plano psicológico, que passa a relacionar desvios ou paradas de desenvolvimento à perversidade de crianças criminosas. $\mathrm{O}$ novo argumento diz que as crianças não aprendem as regras do social, tornando-se criminosas - não porque estão submetidas a traços mórbidos ancestrais cuja modificação é impossível, como em Nina Rodrigues, mas por uma enfermidade dos centros nervosos - não necessariamente inata - que provoca transtornos no desenvolvimento normal da inteligência, 
impossibilitando a adaptação normal ao meio. Nessa nova configuração, a ordenação familiar emerge como elemento-chave na argumentação sobre as causas da criminalidade infantil.

Se a melhor escola do bem que é o lar não cumpre seu papel, cedo a criança se matricula na grande escola do mal que é o rua, dizia o pensamento social. Nesse deslocamento do eixo - de raça para família, de ancestralidade para individualidade, de evolução coletiva da espécie para auto-desenvolvimento -, o elemento de culpabilidade ganha outros contornos. Afinal, qual o status da culpa de um criminoso nato, criminoso porque último elo de um passado ancestral que resiste ao processo civilizatório? Na nova configuração, entretanto, está aberto o trajeto de culpabilização para todos que resistem ao modelo familiar construído para excluir.

Reconfigurado o plano da culpabilização, criam-se os tribunais especiais para crianças no início dos anos 20 , prenúncio da legislação que viria no final da década. Como efeito de um eufemismo, os tribunais não foram criados para julgar, mas para se tornarem espécie de laboratório para estudo do menor, de sua personalidade e de tudo e todos que estão a sua volta. Tendo por base estes conhecimentos, seriam adotadas as medidas mais adequadas para sua salvação moral - e social. Apesar de estruturarem-se como tribunais, esses organismos transformam o julgamento em exame de cada caso, um exame social que exige do juiz conhecimentos que extrapolam o universo legal até então tradicional. $\mathrm{O}$ binômio educação-trabalho ganha novos contornos na escola de reforma, e o trabalho passa a ser arma contra a imoralidade na formação do caráter, processo 
considerado falho no âmbito das famílias pobres. Era preciso pensar no futuro dos futuros criminosos e investigar sobre ofícios e aptidões.

Para a infância criminalizada examinada nos tribunais, os limites da escolarização na formação do caráter passam a ser questionados. Assim como o discurso sobre a incompetência cívica da família pobre reafirma a necessidade da intervenção do Estado no papel educativo, também a escola tem seu poder de modificabilidade interrogado. Apesar de ser nomeada escola de prevenção ou reforma, a regeneração das crianças não poderia ser realizada apenas pela instrução, considerada insuficiente, obra sutil demais no combate à reorganização das almas deformadas antes mesmo da vida e tão cheias de deturpações e de tortuosidades. Doravante procura-se atingir também a alma da criança criminalizada, e sentimentos e emoções passam a ser fundamentais na formação do caráter. Sentimentos e emoções, aliás, que a instrução era impotente para despertar e mais ainda cultivar, diziam os juristas.

Se por um lado o discurso sobre a infância criminalizada sofre essa "internalização", por outro o torvelinho social ganha densidade nas análises. A crítica vazia ao industrialismo ${ }^{232}$ prenuncia a exigência do controle dos destinos do país na defesa de um povo que agora começa a surgir não mais como raça, mas como massa. Apesar do crescimento de quase todas as capitais do país, São Paulo

${ }^{232}$ É preciso salientar, contudo, que contrariamente a análises históricas tradicionais no campo da criminologia, estudos a partir da construção do discurso criminológico no século XIX mostram que havia diferenças muito pouco significativas entre as escolas rivais de antropologia e sociologia criminal, apesar da violenta retórica nos confrontos. O antagonismo entre as duas escolas poderia ser resumido a uma questão de grau, já que ambas partiam do pressuposto da existência do tipo criminoso, que deveria ser segregado e controlado. LEPS, Marie-Christine. Apprehending the criminal. The production of deviance in $19^{\text {th }}$. Century discourse, 1992. 
foi a que mais cresceu, principalmente como centro distribuidor de produtos importados e elo entre a produção cafeeira e o porto de Santos. Em 1920, São Paulo passa o Rio de Janeiro em termos de produção industrial, apesar do governo republicano não promover uma política deliberada de desenvolvimento para a indústria. Sob a condição da nova vida urbana, pais debilitados por excesso de trabalho geram crianças com alimentação insuficiente, que são mergulhadas na ociosidade e tornam-se alvo das sugestões dos criminosos.

A lógica anunciava que, abandonadas não só pela incompetência familiar, mas agora também por um Estado considerado fraco - as crianças pervertem-se e tornam-se delinquentes. Abandonados, pervertidos e delinquentes: essas eram as três divisões do Instituto Disciplinar da capital no início dos anos 20. Neste programa eminentemente utilitário, educar é ensinar a ganhar a própria vida, verificando aptidões, orientando o aprendizado para fins práticos, como os de ofícios ligeiros.

Doravante, entende-se esta criança anormal, inserida na cadeia abandonadopervertido-delinquente, como aquela que teve seu rumo entravado em determinada fase, pegou um caminho paralelo, em direções incertas, sofreu um processo de involução. Não se trata mais de lentidão no desempenho de um elemento psíquico, ou seja, de uma anormalidade da inteligência, de um atraso para o qual bastaria empregar métodos normais. Esta criança criminosa não pode ser entendida como um normal lento ou estabilizado em determinado momento da evolução psíquica. Não é apenas inferior em grau, é uma mentalidade à parte, exigindo portanto uma institucionalização especial, libertando o sistema escolar desse peso morto, cuja 
irritabilidade e instabilidade geram a indisciplina tão indesejada nas homogêneas salas de aula. Psychologistas são chamados a participar dessa vigilância especial exercida sobre os anormais, lado a lado com médicos, educadores e magistrados. Devolvidos ao mundo, esses anormais deveriam ser alvo contínuo da vigilância sob patronagem. Sob essa lógica, a instrução escolar não pode mais ser critério do grau de adaptação social. Educação para o trabalho e aptidão moral dão o contorno da assistência a esses menores na direção da solução desse problema social. Este caráter "prático" da reeducação, como vimos, foi tornando-se cada vez mais presente no cotidiano das crianças de Juquery. Lá, o tratamento da infância criminalizada passou a ser uma espécie de laborterapia que almejava a normalidade do corpo social.

Esta pesquisa não teve como objetivo primeiro desvelar uma fala oculta ou mesmo ideológica por trás do discurso em torno da infância criminalizada. Ou mesmo apontar até que ponto a psicologia nascente (aliás, cabe relativizar a pergunta sobre quantas décadas ela esteve nascente, quando nasce finalmente, e qual a relação entre nascimento e institucionalização da psicologia) funda seu discurso inaugural em pressupostos ideológicos de qualquer ordem. Tampouco buscou-se revelar uma espécie de passagem sem tropeços e suave ao discurso psicológico a partir dos discursos anteriores ou mesmo simultâneos, porém construídos em torno de outros saberes. Tampouco foi a intenção dessa pesquisa 
elaborar uma análise do deslocamento de categorias psicológicas do discurso jurídico ao discurso estritamente psicológico, e seus desdobramentos em formações posteriores.

Não se trata de perscrutar o momento em que os discursos se constituíram, numa espécie de olhada de retrovisor que imaginasse localizar um pretenso "nascimento", o instante em que um saber se movimenta irreversivelmente na direção de uma ciência. Tampouco se trata de apontar o momento em que o discurso jurídico perde parte de seu objeto para outros saberes ao manter incorporadas determinadas categorias que já não lhe eram estruturantes. Não se procurou revelar nos discursos desejos, ódios, ambições ou erros, apesar de em muitos momentos eles lá estarem. Não se tratou de apontar no passado o germe do que surgirá, dizer que tudo tem início não no lugar que se esperava, antecipar profecias, insistir em continuidades, revelar ressonâncias. Não se trata apenas de eleger pensadores por seu ineditismo, reconfigurar filiações teóricas, ou denegrir obras a partir da revelação de projetos políticos até então secretos.

Quando se trata da infância criminalizada a pesquisa revela a regularidade de uma prática discursiva, apesar de exercida a partir de formações com distintas árvores de derivação. A descrição dessa regularidade só foi possível porque a infância criminalizada - enquanto objeto de um saber constituído a partir da virada do século - não foi examinada enquanto objeto teórico, ou como uma dedução a partir de axiomas de discursos fundadores. A série de discursos sobre a infância criminalizada aqui descritos não se constitui a partir de um núcleo inicial que desenvolve suas significações em direções diversas e de forma cada vez mais 
precisa. Como esclarece Foucault a partir de Canguilhem, a história de um conceito não é, de forma alguma, a de seu refinamento progressivo, de sua racionalidade continuamente crescente, de seu gradiente de abstração, mas a de seus diversos campos de constituição e de validade, a de suas regras sucessivas de uso, a dos meios técnicos múltiplos em que foi realizada e concluída sua elaboração. É preciso considerar, portanto, várias redes de determinações, várias teleologias para uma única e mesma ciência, não unificando o momento fundador em precursores, pioneiros e sucessores.

A pesquisa aqui empreendida também foi orientada no sentido de marcar relações entre as formações discursivas e domínios não-discursivos, definindo formas específicas de articulação entre práticas discursivas e instituições ou processos econômicos. Buscamos situar a emergência da infância criminalizada num país recém-saído da escravidão e imerso em uma Primeira República que se desrepublicanizava ano a ano. Ao materializar a infância criminalizada em uma população enquadrada e fiscalizada por uma lógica policial - incluindo-se aí a família pobre -, a prática política assim configurada nas instituições analisadas demarcou novos objetos para a psicologia. Por outro lado, ao demarcar objetos da ordem das classes perigosas, o discurso psicológico também assinala deslocamentos no campo da normalidade que teriam consequências desastrosas para a institucionalização da prática psicológica nas gerações seguintes. ${ }^{233}$ Primeiros sinais dessa cisão do discurso psicológico - uma especialização dos saberes conforme certa escala social orientando a formação de objetos da psicologia - foram

\footnotetext{
${ }^{233}$ A esse respeito, ver a crítica fundante da psicologia escolar realizada por PATTO, Maria Helena Souza. A produção do fracasso escolar: histórias de submissão e rebeldia, 1987.
} 
apontados quando se descreveu como o discurso sobre a criança histérica não se aplicava à criança que tinha no trabalho sua salvação moral.

A legitimação crescente porém irregular que o discurso psicológico recebe (quando, por exemplo, afirma-se a necessidade de conhecimento psicológico no julgamento de crianças, ou mesmo quando a criminologia se coloca como ciência psíquica) parece indicar uma história paralela àquela que levaria o psicólogo a ocupar o lugar de titular desse mesmo discurso, o que só ocorreria décadas depois. Por outro lado, os percalços nessa legitimação mostram como a prática política de uma dada sociedade constituiu e modificou as categorias psicológicas e a estrutura teórica constituidora da infância criminalizada. $\mathrm{O}$ discurso psicológico como prática que se constitui na busca de um campo próprio de objetos, apesar de não apresentar ainda certos estatutos legitimadores, articulou-se em práticas que lhe são exteriores e que não são de natureza discursiva.

A descrição do discurso sobre a infância criminalizada empreendida quis enfatizar seu grau zero de independência histórica, suas relações com o domínio das instituições, dos processos econômicos e das relações sociais. Portanto, não se trata de localizar e alojar projetos políticos em um discurso determinado. É preciso sim analisar o grau e a forma da permeabilidade de um discurso, sem transformá-lo na consciência de uma classe, mentalidade de um grupo social, ou muito menos setor profissional.

A pesquisa também mostrou que a substituição de uma formação discursiva por outra não significou a emergência de um universo inteiriço de opções teóricas absolutamente novas. Dizer que uma formação discursiva substitui outra não é 
dizer que todo um mundo de enunciações, conceitos, escolhas teóricas absolutamente novas ou inéditas surgem prontos à análise. A pesquisa mostrou que "educar" a infância criminalizada aparece de distintas formas, alterando o lugar reservado às categorias psicológicas no discurso, sem no entanto operar uma mudança radical em determinadas opções teóricas ou mesmo políticas. Esta educabilidade - sempre informada por categorias psicológicas - é moralizadora na cultura espiritual de Tobias Barreto, é treinamento para trabalhos específicos durante crise de mão-de-obra, é tratamento moral bem-sucedido para corrigir vícios, é tratamento moral sem garantia de sucesso para corrigir taras herdadas, é equilíbrio para as funções do cérebro, é tratamento psicofísico, é aprendizagem de regras do social, é minimizar a escolarização, é vigilância permanente. Inteligência, por sua vez, não surge como categoria fundamental no início da criminologia brasileira, e passa a ser categoria sem a qual não se explica o crime praticado na infância alguns anos depois, apesar de certas modificações estruturais no processo de institucionalização das crianças sofrerem um descompasso.

Há sim novas regras na formação dos discursos, como por exemplo diferenças no patamar de importância atribuída a determinadas categorias psicológicas, mas a partir dessas novas regras podem ser descritos e analisados fenômenos de continuidade, de retorno e de repetição. Um exemplo dessa regra aparentemente paradoxal é a "nova" versão do discurso da eugenia que aparece nos anos 20, que repete de forma impressionante o peso da raça (agora entendida como "grupo" étnico) nas análises de degeneração social. Ou seja, apesar dos enunciados obedecerem a novas regras de formação, nem todas as escolhas teóricas 
desapareceram. É assim que categorias secundárias em uma formação reaparecem em posição dominante em outra, ou mesmo determinados elementos reaparecem após um "esquecimento social". Sob o ponto de vista da história da psicologia, um exemplo definitivo dessa regra é a notável dispersão de categorias necessárias para substituir "discernimento" no discurso sobre a criança criminosa. Paradoxalmente, na lei de 1927 discernimento é entendido como "enigma psicológico".

A pesquisa procurou também descrever os lugares institucionais a partir de onde a psicologia construiu sua linguagem e em que momentos esta encontrou formas legítimas e seu ponto de aplicação por meio de objetos específicos. No caso da infância criminalizada, a linguagem psicológica teve em primeiro plano a instância jurídica como lugar de observação constante, estruturando um campo documentário que ganha contornos mais firmes na massa de informações e estatísticas produzida nas instituições jurídicas e médico-pedagógicas. Se o hospital tornou-se para o médico um local de observações sistemáticas - antes apenas um apoio para o discurso sobre as doenças - o tribunal para crianças assume para o jurista o peso de um laboratório, pretendendo-se assim aproximar a criminologia de uma ciência psíquica e suas normas experimentais.

$\mathrm{O}$ trajeto da pesquisa foi orientado no sentido de procurar quem fala quando fala a psicologia, considerando-se momentos anteriores a sua institucionalização. Questionou-se quais seriam as rotas desta linguagem própria, e quais as razões para que determinado discurso escolhesse determinadas categorias psicológicas para 
fazer emergir o objeto infância criminalizada. Foi construída uma série de formas emergentes desse discurso, cada qual compreendendo critérios de competência do saber ali exposto. A fala sobre a infância criminalizada obedeceu portanto a um sistema que envolveu uma divisão de atribuições (quem julga, quem classifica, quem pune) e uma subordinação hierárquica entre os saberes (jurista, médico, educador). No que se refere à infância criminalizada, em nenhum momento da pesquisa foi possível localizar um papel específico para o psicólogo enquanto elemento portador de um saber demandado, apesar da psicologia enquanto ciência já ocupar um lugar complementar no interdiscurso de outros saberes legitimados.

Esta questão suscitada pela pesquisa diz respeito ao panorama internacional de institucionalização da psicologia. Enquanto em 1892 na Universidade de Clark nos Estados Unidos Stanley Hall foi o primeiro doutor em filosofia com orientação em psicologia, e junto com 31 especialistas fundou a primeira associação de psicólogos no mundo, a American Psychological Association, na Alemanha a institucionalização das práticas psicológicas se realiza durante o período nazista. $\mathrm{Na}$ Argentina a primeira Sociedade de Psicologia [de 1908 a 1913] não mostra o projeto de um campo autônomo de aplicação, e sim que as aplicações se desenvolveram em outros campos já conformados, como por exemplo o campo educativo e medico-criminológico, dado que mereceria uma análise comparativa com o Brasil.

Ressaltamos, contudo, que a prática discursiva não coincide com a elaboração científica a que pode eventualmente dar lugar. Fica claro portanto que não se pode identificar as formações discursivas nem a uma ciência ( $a$ psicologia), 
nem a uma disciplina pouco científica ( $a$ "psicolástica", ou mesmo a ortopedia moral) nem, finalmente, a formas que excluem qualquer cientificidade (o racismo). As formações aqui apresentadas apontam para o antecedente do que se revelará "como um conhecimento ou uma ilusão, uma verdade admitida ou um erro denunciado, uma aquisição definitiva ou um obstáculo superado". ${ }^{234}$ Não se trata de um pré-conhecimento, trata-se dos elementos que devem ter sido formados por uma prática discursiva para que, eventualmente, se constituísse um discurso científico. No eixo prática discursiva-saber-ciência, o saber formado pela prática discursiva não é um esboço ou subproduto de uma ciência já constituída, como se poderia afirmar em relação à presença de categorias psicológicas no discurso jurídico. Não se trata de apontar no discurso jurídico uma psicologia "menor", dissipando o saber que a cerca como ciência, definindo entre saber e ciência uma relação de exclusão, como se houvesse um núcleo irredutível de saber impedindo o nascimento (de novo) de tal ciência, ou mesmo confundindo esse saber com ideologia. Procurou-se aqui mostrar como uma ciência como a psicologia se inscreveu e funcionou no elemento do saber, sem se identificar com ele, e lá estruturou alguns de seus objetos e sistematizou algumas conceitualizações.

É nesse espaço de ação que se estabelecem e se especificam as relações da ideologia com as ciências. Segundo Foucault, a influência da ideologia sobre o discurso científico e o funcionamento ideológico das ciências não se articulam no nível de sua estrutura ideal, nem no nível de sua utilização técnica em uma sociedade, nem no nível da consciência dos sujeitos que a constróem; articulam-se

\footnotetext{
${ }^{234}$ FOUCAULT, M. Arqueologia do saber, p. 206.
} 
onde a ciência se destaca sobre o saber. Qualquer descrição mais precisa das relações entre estrutura epistemológica da psicologia e sua função ideológica deverá passar pela análise das formações discursivas que lhe deram lugar e do conjunto de objetos, conceitos e escolhas teóricas que lá foram elaborados e sistematizados. O funcionamento ideológico da psicologia se revela em seu sistema de formação de objetos, conceitos e escolhas teóricas, e não apenas na revelação de pressupostos filosóficos ou fundamentos que a legitimam. 


\section{Fontes e Bibliografia}

Relatórios oficiais e periódicos

BOLETIM Trimestral de Estatistica Demographo-Sanitaria do Estado de S.Paulo. Anno XXV, n.1/2/3/4, 1918. Diario Oficial. Directoria do Serviço Sanitario do Estado de S. Paulo.

O ESTADO de São Paulo. Secção Medicina e Hygiene (1922-1925)

ARQUIVO PÚBLICO MUNICIPAL. Fundação Arquivo e Memória de Santos. Processos de menores. Juízo de Direito. Cx1. Maços 102, 119, 130, 178, 234.

RELATÓRIO apresentado ao Senhor Doutor Vice-presidente do Estado de São Paulo pelo Secretário dos Negócios de Justiça Manoel Pessôa de Siqueira Campos a 7 de abril de 1892. São Paulo, Typographia Edelbrok e Moreira, 1892.

RELATÓRIO apresentado ao Presidente do Estado pelo Secretário de Negócios Jurídicos de São Paulo Manoel Pessôa de Siqueira Campos em 31 de março de 1893. Rio de Janeiro, Typographia G. Luizinger \& Filhos, 1893.

RELATÓRIO apresentado ao Presidente do Estado pelo Secretário de Negócios da Justiça de São Paulo Manoel pessoa de Siqueira Campos em 31 de março de 1894. São Paulo, Typographia a vapor Espindola, Siqueira e Comp., 1894.

RELATÓRIO apresentado ao Presidente do Estado pelo Secretário Interino dos Negócios da Justiça de São Paulo João Alvarez Rubião Jr em 31 de dezembro de 1894. São Paulo, Typographia a vapor Espindola, Siqueira e Comp., 1895.

RELATÓRIO apresentado ao Presidente do Estado pelo Secretário de Negócios da Justiça de São Paulo João Baptista de Mello Peixoto em 31 de dezembro de 1895. São Paulo, Typographia a vapor Espindola, Siqueira e Comp., 1896.

RELATÓRIO apresentado ao Presidente do Estado pelo Secretário de Negócios da Justiça de São Paulo Carlos de Campos em 31 de dezembro de 1896. São Paulo, Typographia a vapor Espindola, Siqueira e Comp., 1897. 
RELATÓRIO apresentado ao vice-presidente do Estado pelo Secretário dos Negócios da Justiça de São Paulo José Getulio Monteiro em 31 de dezembro de 1897. São Paulo, Typographia a vapor Espindola, Siqueira e Comp., 1898.

RELATÓRIO correspondente ao anno de 1898 apresentado ao Presidente do Estado Coronal Fernando Prestes de Albuquerque pelo Dr. José Pereira de Queiroz, Secretário dos Negócios da Justiça de São Paulo, Typographia do Diario Official.

RELATÓRIO apresentado ao Dr. Francisco de Paulo Rodrigues Alves Presidente do Estado pelo Dr. Francisco de Toledo Malta Secretário Interino da Justiça. Annos de 1899 e 1900. São Paulo, Typographia do Diario Official, 1901.

ROCHA, Franco da. Estatística e Apontamentos. Hospício de Alienados. São Paulo, Diário Oficial, 1898.

ROCHA, Franco da. Estatísticas e Apontamentos. Hospício de Alienados. São Paulo, Diário Oficial, 1899.

ROCHA, Franco da. Estatísticas e Apontamentos. Hospício de Alienados. São Paulo, Diário Oficial, 1900.

ROCHA, Franco da. Estatísticas e Apontamentos. Hospício de Alienados. São Paulo, Diário Oficial, 1901.

Livros, periódicos e obras de referência

AMERICAN JOURNAL OF PSYCHOLOGY. v.31, 1920.

AZEVEDO, Noé. Dos tribunaes especiaes para menores delinquentes e como podem ser creados entre nós. Theses para obter o grao de doutor em sciencias sociaes e juridicas. São Paulo, s/e, 1920.

ARQUIVOS da Sociedade de Medicina Legal e Criminologia de S.Paulo, v.I n.1, 1922. ARQUIVOS da Sociedade de Medicina Legal e Criminologia de S.Paulo, v.II ano 2, novembro de 1927.

BAPTISTA, Vicente. O problema da assistencia e protecção á infancia. In: Pediatria Prática. Revista Mensal de Clinica Infantil e Puericultura. v.3. julho de 1930.

BAPTISTA, Vicente. Relatório apresentado pelo dr. Vicente Baptista á directoria do Hospital de Juquery. In: Pediatria Practica. Revista Mensal de Clinica Infantil e Puericultura. V.3. janeiro de 1931. 
BAPTISTA, Vicente. Escola Pacheco e Silva. Relatório apresentado ao Dr. Diretor do Hospital de Juquerí. In: Pediatria Pratica. V.IV. janeiro/fevereiro, 1932. pp.179-185.

BAPTISTA, Vicente. "Relatório apresentado ao Diretor Geral da Assistencia a Psicopatas". In: Pediatria Practica. Revista Mensal de Clinica Infantil e Puericultura. v.IV.janeiro e fevereiro de 1933.

BAPTISTA, Vicente. "Secção de Menores Anormais do Hospital Central de Juquery. Serviço de Assistência a psicopatas". In: Arquivos do Serviço de Assistência a Psicopatas do Estado de São Paulo. Ano III. $1^{\circ}$. e $2^{\circ}$. trimestres, 1938. pp.251-258.

BRITO, Raimundo de Farias. A base physica do espirito. História summaria do problema da mentalidade como preparação para o estudo da philosophia do espirito. Rio de Janeiro, Francisco Alvez, 1912.

BARRETO DE MENEZES, Tobias. Menores e loucos em direito criminal. Rio de Janeiro, Simões, [1884] 1951.

CABANIS, P.J.G. Rapports du Psysique et du Moral d l'homme et lettre sur les causes premières. $18^{\mathrm{a}}$ ed. Paris, Baillière. Capítulo intitulado "De l'influence des âges sur les idées e les affections morales", 1844.

CAMPELLO, Barreto. Da individualização da pena. Recife, Revista da Cidade, 1927.

COLLET, Agenello Geraque. Hygiene escolar. Salvador, s/e, 1895.

COUTO, Antonio Maria do. Diccionário da maior parte dos termos homonymos e equivocos da Lingua Portugueza. Lisboa, Typographia de Antonio Joze da Rocha, 1842.

GALTON, Francis. Essays in eugenics. London, The Eugenic Education Society, 1909.

GODDARD, Henry Herbert. The Kallikak family. A study in the heredity of feeblemindedness. New York, Arno Press, [1912] 1972 (Classics in Psychology).

GONÇALVES, Antonio Ribeiro. Menores delinquentes, Salvador, s/e, 1902.

GUANABARA, Alcindo. Pela infância abandonada e delinquente do Distrito Federal. Exposição de motivos e projecto de lei apresentado ao Senado Federal na Sessão de 21 de agosto de 1917. Rio de Janeiro, Typographia do Jornal do Commercio, 1917.

HAECKEL, Ernst. História da creação dos seres organisados segundo as leis naturais. Porto, Chardron, 1912 [Natürliche Schöpfungsgeschichte, 1868].

HAECKEL, Ernst. O monismo. Porto, Chardron, 1908.

HALL, G. Stanley. Aspects of child life and education. New York/London, D. Appleton, [1907] 1921.

HEUYER, Georges. Enfants anormaux et délinquants juvéniles. Necessité de l'examen psychiatrique des écoliers. Paris, G. Steinheil, 1914. 
INGENIEROS, J. El hombre mediocre. Cidade de Mexico, Porrúa, [1913] 1998.

LE BON, Gustav. Psychology des foules. Paris, PUF, [1895] 1998.

LEWS, W. B. "The treatment of insanity". In: A text-book of mental diseases. London, Charles Greffen and Cia, 1899.

LOBO, Francisco Candido da Silva Lobo. Apontamentos para o estudo da Hygiene escolar. Salvador, s/e, 1895.

LOPES, Ernani. "Das psychoses infantis e especialmente da paralysia geral infantil". In: Actas de la Primeira Conferencia Latino Americana de Neurologia, Psiquiatria e Medicina Legal, 1928, pp.442-469.

LYRA, João Maria Carneiro de. Hysteria Infantil. Theses apresentadas á Faculdade de Medicina da Bahia. Bahia, Imprensa Popular, 1891.

MAGALHÃES, Basilio de. Tratamento e educação das creanças anormaes de intelligencia. Contribuição para o estudo desse complexo problema scientifico e social, cuja solução urgentemente reclamam, - a bem da infancia de agora e das gerações porvindouras, - os mais elevados interesses materiais, intellectuais e moraes da Patria Brasileira. Rio de Janeiro, Typ. Do Jornal do Commercio, 1913.

MARCONDES, Durval e colaboradores. Noções Gerais de higiene mental da criança. São Paulo, Martins, 1946.

MARQUES, J. C. Menores abandonados e delinquentes. Exposição analytica e commentada da lei federal n.4242 de 5 de janeiro de 1921 e seu regulamento aprovado pelo Decreto n.16.272 de 20 de dezembro de 1923, e da Lei Paulista n. 2059 de 31 de dezembro de 1924 por Joaquim Candido de Azevedo Marques. São Paulo, Livraria Acadêmica, 1925.

MENDES, Fernando. Diccionario da lingua portugueza. Prosodico e orthographico. Lisboa, João Romano Torres Editor, 1905.

MORAES, Evaristo de. Creanças abandonadas e creanças criminosas. Rio de Janeiro, Moraes, 1900.

MORAES, Evaristo de. Criminalidade da infância e da adolescencia. São Paulo, Francisco Alves. [1916] 1927.

MORAES SILVA, Antonio de. Diccionario da Lingua Portugueza recopilado dos vocabularios impressos até agora, e nesta Segunda edição novamente emendado, e muito acrescentado, oferecido ao Príncipe Regente. Lisboa, Typographia Lacerdina, 1813. 2 volumes. 
MOTTA, Candido Nogueira da. Os menores delinquentes e o seu tratamento no Estado de São Paulo. São Paulo, Diario Oficial, 1909.

NACHÂT, Hassa. Le jeunes délinquents. Paris, Rousseau, 1913.

PACHECO E SILVA, A.C. A assistencia a alienados nos Estados Unidos e na Europa. Relatorio de viagem apresentado ao Exmo. Snr. Dr. José Manuel Lobo, D.D. Secretario do Interior, em 24 de dezembro de 1926.

PATURI, José Lopes. Hygiene infantil. Salvador, s/e, 1898.

PAULA SOUZA, G. H. Algumas considerações sobre a mortalidade infantil em São Paulo. Faculdade de Medicina e Cirurgia de S. Paulo. Instituto de Hygiene. Boletim 18. Memoria escripta pelo dr. G. H. Paula Souza, Director Geral do Serviço Sanitario do Estado de S.Paulo, lida no $1^{\circ}$ Congresso de Hygiene reunido no Rio de Janeiro, em 1 de outubro de 1923.

PAUlA SOUZA, G.H. O Estado de São Paulo e alguns dos seus serviços de saude publica. Memoria escripta pelo dr. G. H. Paula Souza, Director Geral do Serviço Sanitario do Estado de S.Paulo, lida no $1^{\circ}$ Congresso de Hygiene reunido no Rio de Janeiro, em 1 de outubro de 1923.

PAULA SOUZA, G. H. Serviço de Estatistica sanitaria. Faculdade de Medicina e Cirurgia de S. Paulo. Instituto de Hygiene. Boletim 19, 1924.

REIS, Álvaro Borges dos. Educação Physica. Salvador, s/e, 1904.

ROCHA, Franco da. Fragmentos de Psyquiatria. São Paulo, Hospício de S. Paulo, 1895.

ROCHA, Franco da. "Assistência a alienados". O Estado de S. Paulo, 20 de agosto de 1920 .

RODRIGUES, Nina. As raças humanas e a responsabilidade penal no Brasil. $3^{\mathrm{a}}$ ed. feita sobre a primeira de 1894 e prefaciada por Afranio Peixoto. São Paulo, Rio de Janeiro, Recife, Porto Alegre, Companhia Editora Nacional, [1894] 1938. Brasiliana, Biblioteca Pedagógica Brasileira.

RODRIGUES, Nina. "Legislação sobre assistência a alienados". In: Arquivos brasieliros de Psiquiatria, Neurologia e Ciências afins 2: 299-387, 1906.

RODRIGUES, Nina. Os africanos no Brasil. $5^{\mathrm{a}}$ ed. São Paulo, Companhia Editora Nacional, [1905] 1977.

ROSAS Filho, Tito dos Passos. Da responsabilidade dos menores. Dissertações e Theses apresentadas á Faculdade de Direito. Recife, Pantheon das Artes, 1895.

ROUBINOVITCH, Jacques. Alienénés et anormaux. Paris, Feliz Alcan, 1910. 
SAMPAIO DORIA, A. de. Princípios de Pedagogia. Ensaios. São Paulo, Pocai-Weiss Editores, 1914.

SAMPAIO DORIA, A. de. Ensaios. O caracter e a mocidade, Saudação e Pela Pátria. São Paulo, Pocai-Weiss Editores, 1915.

SILVA, Pedro. Assistencia aos menores anormaes. Subsidios para o seu estudo em S.Paulo. These de Doutoramento apresentada em 15 de janeiro de 1931. Cadeira de Clinica Psychiatrica e Neuriatrica (Trabalho do Hospital do Juquery), 1931.

\section{Bibliografia}

ADORNO, T.W. Consignas. Buenos Aires, Amorrortu, s/d.

AGAMBEN, Giorgio. Infancy and history. Essays on the destruction of experience. London/New York, Verso, 1993.

ALVAREZ, Marcos César. A emrgência do código de menores de 1927. Uma análise do discurso jurídico e institucional da assistência e proteção aos menores. Dissertação (mestrado), Sociologia, FFLCH/USP, 1989.

ARIÈS, Philippe. História social da criança e da família. 2a . ed., Rio de Janeiro, Zahar, 1981.

ASSIS, Márcio Branco de. A criança e a ordem. Teoria e prática jurídica no tratamento da criança desviante na belle époque carioca. Dissertação (mestrado) em História social, FFLCH/USP, 1997.

ASSUMPÇAO Jr., Francisco. Psiquiatria infantil brasileira. Um esboço histórico. São Paulo, Lemos, 1995.

BENOIT, Lelita Oliveira. Sociologia comteana: gênese e devir. São Paulo, Discurso Editorial, 1999.

BERCHERIE, P. Os fundamentos da clínica. História e estrutura do saber psiquiátrico. Rio de Janeiro, Zahar, 1989.

BERNHARDT, Jean. "Hobbes". In: Châtelet, François (org.). História da filosofia. A filosofia do mundo novo. Séculos XVI e XVII. 2a . ed., Rio de Janeiro, Zahar, 1982.

BOURDIEU, P. 'O campo científico'. In: Ortiz, R. (org.). Pierre Bourdieu. São Paulo, Ática, 1994 (Coleção Grandes Cientistas Sociais).

BRAUNSTEIN, J-F. e PEWZNER, Évelyne. Histoire de la psychologie. Paris, Armand Colin 1999. 
BUCK-MORSS, Susan. The origin of negative dialectics. New York, Free Press, 1977.

BROZEK, J. e MASSIMI, M. (orgs) Historiografia da psicologia moderna. Versão brasileira. São Paulo, Loyola/Unimarco, 1998.

BULCÃO, Ana lucia Eppinghaus. Meninos maiores. O conflito da menoridade e maioridade no Rio de Janeiro entre 1890 e 1927. Dissertação (mestrado) em HIstória, Universidade Federal do Rio de Janeiro, 1992.

BURKE, Peter. A Escola dos Annales (1929-1989): a revolução francesa da historiografia. Tradução de Nilo Odalia. São Paulo, Unesp, 1997.

CAMPOS, Regina Helena de Freitas (org.). História da psicologia: pesquisa, formação, ensino. São Paulo, Educ/Anpepp, 1996.

CANGUILHEM, Georges. O normal e o patológico. Tradução de Maria Thereza Redig de Carvalho Barrocas e Luiz Octávio Ferreira Barreto. $4^{\text {a }}$ ed., Rio de Janeiro, Forense Universitária, 1995.

CARVALHO, José Murilo de. Os bestializados. São Paulo, Companhia das Letras, 1997.

CARVALHO, José Murilo de. A formação das almas. O imaginário da República no Brasil. São Paulo, Companhia das Letras, 1998.

CARVAlHO, José Murilo de. Pontos e bordados. Escritos de história e política. Belo Horizonte, UFMG, 1999.

CHARTIER, R. El mundo como representacion. Estudios sobre historia cultural. Barcelona. Gredisa, 1995.

COMAS e outros. Raça e ciência I e II. São Paulo, Perspectiva, 1970.

CORRÊA, Mariza. As ilusões da liberdade. A escola Nina Rodrigues e a Antropologia no Brasil. Bragança Paulista, Edusf, 1998.

COSTA, João Cruz Costa. O positivismo na República. Notas sobre a história do positivismo no Brasil. São Paulo, Companhia Editora Nacional, 1956.

COSTA, João Cruz Costa. Contribuição à história das idéias no Brasil. Rio de Janeiro, José Olímpio, 1956.

COSTA, Jurandir Freire. Ordem médica e norma familiar. $3^{\mathrm{a}}$ ed., Rio de Janeiro, Graal, 1989.

CUNHA, Maria Clementina Pereira. O espelho do mundo. Juquery, a história de um asilo. $2^{\mathrm{a}}$ ed. Rio de Janeiro, Paz e Terra, 1988.

CYTRYNOWICZ, R. e ZUQUIM, J. “A psicologia escoteira: teoria do caráter como pedagogia de civismo". In: Anais do XXVII Congresso da Sociedade Interamericana de Psicologia. Caracas, 1999. 
DANZIGER, K. 'Generative metaphor and the history of psychology.' In: Leary, D. (Ed.). Metaphors in the history of Psychology. Cambridge University Press, 1990.

DANZIGER, K. Naming the mind. How psychology found its language. London/Thousand Oaks/New Delhi, Sage Publications, 1997.

DEL PRIORE, Mary (org.) História das crianças no Brasil. São Paulo, Contexto, 1999.

DOSSE, François. A história em migalhas: dos Annalles à Nova História. Tradução de Dulce da Silva Ramos. São Paulo/Campinas, Ensaio/Editora da Universidade Estadual de Campinas, 1992.

DOSSE, François. L'histoire. Paris, Armand Colin, 2000.

DUCHESNEAU, François. "A filosofia anglo-saxônica de Bentham a William James”. In: CHATELET, François. A filosofia do mundo científico e industrial. Rio de Janeiro, Zahar, 1983.

EAGLETON, T. 'A ideologia e suas vicissitudes no marxismo ocidental'. In: ZIZEK, S. (org.) Um mapa da ideologia. Rio de Janeiro, Contraponto, 1996.

FAIRCLOUGH, Norman. Critical discourse analysis. The critical study of language. London/New York, Longman, 1998.

FAUSTO, Boris. História do Brasil. $4^{\text {a }}$ ed. São Paulo, Edusp, 1996.

FIGUEIREDO. Luiz Claudio M. Matrizes do pensamento psicológico. $3^{\mathrm{a}}$ ed. Petrópolis, Vozes, 1991.

FOUCAULT, Michel. História da loucura na Idade Clássica. Tradução de José Teixeira Coelho Netto. São Paulo, Perspectiva, 1978.

FOUCAULT, Michel. A arqueologia do saber. Tradução de Luiz Felipe Baeta Neves. Rio de Janeiro, Forense-Universitária, 1987.

FREITAS, Marcos Cezar (org.). História social da infância no Brasil. São Paulo, Cortez, 1997.

FREITAS, Marcos Cezar (org.). Historiografia brasileira em perspectiva. São Paulo, Contexto, 1998.

GAGNEBIN, Jeanne Marie. Sete aulas sobre linguagem, memória e história. São Paulo, Imago, 1997.

GÈLIS, Jacques. "A individualização da criança". In: História da vida privada v.3, pp311-329. 
GEUTER, Ulfried. The profissionalization of psychology in Nazi German [Die Professionalisierung der deutschen Psychologie im Nationalsozialismus]. Cambridge University Press, 1992.

GOULD, S. J. A falsa medida do homem. São Paulo, Martins Fontes, 1991.

GREIMAS, A. J. Análise do discurso em ciências sociais. São Paulo, Global 1986.

HALL, Catherine. "Sweet home”. In: Michelle Perrot et all (org.) História da vida privada v. 4. Da revolução francesa à primeira guerra. São Paulo, Cia das Letras, pp.53-87, 1991.

HELLER, Agnes. Sobre os instintos. Lisboa, Editorial Presença, 1983.

HELLER, Agnes. Teoría de la historia. Barcelona, Fontamara, 1982.

HOBBES, Thomas. Leviatã I. 2a . ed., São Paulo, Abril Cultural, 1979 (Os pensadores).

HOBSBAWM, E. A era do capital. Tradução de Luciano Costa Neto. Rio de Janeiro, Paz e Terra, 1997.

HOBSBAWM, E. Era dos extremos: o breve século XX. Tradução de Marcos Santarrita. São Paulo, Companhia das Letras, 1995.

HOBSBAWM, E. Sobre história. São Paulo, Cia das Letras, 1998.

HORKHEIMER, M. 'Teoria tradicional e teoria crítica'. In: Textos escolhidos. São Paulo, Abril Cultural, 1980 (Coleção Os pensadores).

HORKHEIMER, M. e ADORNO, T. W. Dialética do esclarecimento: fragmentos filosóficos. Rio de Janeiro, Zahar, 1985.

JACOB, François. La logique du vivant. Une histoire de l'hérédité. Paris, Gallimard, 1970. JAMESON, F. O marxismo tardio. Adorno ou a persistência da dialética. São Paulo, Unesp/Boitempo, 1997

JORDANOVA, Ludmilla. "New worlds for children in the eighteenth century: problems of historical interpretation". In: History of the Human Sciences, v.3., n.1. pp.70-83.

KEITH, Thomas. O homem e o mundo natural. Mudanças de atitude em relação às plantas e aos animais 1500-1800. São Paulo, Companhia das Letras, 1988.

LALANDE, André. Vocabulário técnico e crítico da filosofia. São Paulo, Martins Fontes, 1993.

LEARY, David E. (org.) Metaphors in the history of psychology. Cambridge, Cambridge University Press, 1994.

LEPS, Marie-Christine. Apprehending the criminal. The production of deviance in $19^{\text {th }}$. Century discourse. Durham and London, Duke University Press, 1992. 
LIFTON, Robert Jay. The nazi doctors. Medical Killing and the Psychology of Genocide. Harper Collins/Basic Books, 1986.

LIMA, Hermes. Tobias Barreto. A época e o homem. $2^{\text {a }}$ ed. São Paulo, Nacional, 1957.

LONDOÑO, Fernando Torres. “A origem do conceito 'menor"”. In: Priore, Mary del (org.)

História da criança no Brasil. $3^{\text {a }}$ ed. São Paulo, Contexto, 1995, pp.129-145

MACLEOD, David. Building character in the american boy. The Boy Scouts, YMCA, and their forerunners, 1870-1920. London, University of Wisconsin Press, 1983.

MAIO, Marcos Chor (org.). Raça, ciência e sociedade. Rio de Janeiro, Fiocruz, 1996.

MAINGUENEAU, Dominique. Termos-chave da análise do discurso. Tradução de Márcio MAINGUENEAU, Dominique. Novas tendências em análise do discurso. $3^{\mathrm{a}}$ ed. Tradução de Freda Indursky. São Paulo/Campinas, Pontes/Editora da Unicamp, 1997.

Venício Barbosa e Maria Emilia Amarante Torres Lima. Belo Horizonte, Editora UFMG, 1998.

MARCILIO, Maria Luiza. História social da criança abandonada. São Paulo, Hucitec, 1998.

MASSIMI, Marina. A psicologia em instituições de ensino brasileiras no século XIX. Tese (doutorado) em Psicologia, Instituto de Psicologia/USP, 1989.

MASSIMI, Marina. História da psicologia brasileira. Da época colonial até 1934. São Paulo, E.P.U., 1990.

MATTOSO, Kátia de Queirós. "O filho da escrava”. In: Priore, Mary del (org.) História da criança no Brasil. $3^{\text {a }}$ ed. São Paulo, Contexto, 1995, pp.76-97.

MENDES, Emilio García. Infância e cidadania na América Latina. Tradução de Angela Maria Tijiwa. São Paulo, Hucitec, 1998.

MENDES, Roberto Teixeira. Trabalho e doutrina: os caminhos da prática pediátrica nos centros de saúde. Campinas, 1996. Tese (Doutorado) Universidade Estadual de Campinas. Faculdade de Ciências Médicas.

MONTEIRO, John Manual. “As raças indígenas no pensamento brasileiro do Império”. In: MAIO, Marcos Chor e SANTOS, Ricardo Ventura. Raça, ciência e sociedade. Rio de Janeiro, Fiocruz, 1996.

MOURA, Esmeralda Blanco Bolsonaro de. "Infância operária e acidente de trabalho em São Paulo". In: Priore, Mary del (org.) História da criança no Brasil. $3^{\mathrm{a}}$ ed. São Paulo, Contexto, 1995, pp.112-128.

NADAI, E. Ideologia do progresso e ensino superior. São Paulo, Loyola, 1987. 
PASSETTI, Edson. “Crianças carentes e políticas públicas”. In: PRIORE, Mary del. (org.) História das crianças no Brasil. São Paulo, Contexto, 1999.

PATTO, Maria Helena Souza. A produção do fracasso escolar: histórias de submissão e rebeldia. Instituto de Psicologia/USP (Livre-docência), 1987.

PATTO, Maria Helena Souza. "Estado, ciência e política na Primeira República: a desqualificação dos pobres". Estudos Avançados 35, janeiro/abril de 1999.

PATTO, Maria Helena Souza. Mutações do cativeiro. Escritos de psicologia e política. São Paulo, Hacker/Edusp, 2000.

PÊCHEUX, M. O discurso: estrutura ou acontecimento. Campinas, Pontes, 1990.

PEREIRA, Lygia Maria de. Reformas da ilusão: a terapêutica psiquiátrica em São Paulo na primeira metade do século XX. Faculdade de Ciências Médicas/Unicamp (tese de doutorado), 1995.

PERROT, Michelle. "A família triunfante”. In: Michelle Perrot et all (org.) História da vida privada v. 4. Da revolução francesa à primeira guerra. São Paulo, Cia das Letras, pp.94-103, 1991.

PERROT, Michelle. "Funções da família". In: Michelle Perrot et all (org.) História da vida privada v. 4. Da revolução francesa à primeira guerra. São Paulo, Cia das Letras, pp.104-119, 1991

PERROT, Michelle. "Figuras e papéis". In: Michelle Perrot et all (org.) História da vida privada v. 4. Da revolução francesa à primeira guerra. São Paulo, Cia das Letras, pp.120$185,1991$.

PESSOA, Lilian de Abreu. Aspectos do pensamento alemão na obra de Tobias Barreto. Boletim 46. Departamento de Letras Modernas/USP. São Paulo, 1985.

PESSOTTI, Isaías. Deficiência mental: da superstição à ciência. São Paulo, T.A Queiroz/Edusp, 1984.

PINELL, Patrice. "L'invention de l'echelle métrique de l'intelligence". Actes de la recherche en sciences sociales 108, juin 1995, pp.18-35.

PINTO, Milton José. Comunicação e discurso. São Paulo, Hacker, 1999.

PLATT, Anthony M. The invention of delinquency. $2^{\mathrm{a}}$ ed. enlarged. Chicago, University of Chicago Press, 1977.

PRIORI, Mary del (org.). História das crianças no Brasil. São Paulo, Contexto, 1999.

RAGO, Margareth. Do cabaré ao lar. A utopia da cidade disciplinar 1890-1930. $3^{\mathrm{a}}$ ed., Rio de Janeiro, Paz e Terra, 1997. 
RAGO, Margareth. Os prazeres da noite. Prostituição e códigos de sexualidade feminina em São Paulo (1890-1930). Rio de Janeiro, Paz e Terra, 1991.

RAMOS, Jair de Souza. "Dos males que vêm com o sangue: representações raciais e a categoria do imigrante indesejável nas concepções sobre imigração da década de 20”. In: In: MAIO, Marcos Chor e SANTOS, Ricardo Ventura. Raça, ciência e sociedade. Rio de Janeiro, Fiocruz, 1996.

RIOS, J. C e TALAK, Ana Maria. "La articulación entre el saber académico y diversas prácticas de la psicologia, en la Sociedad de Psicologia de Buenos Aires entre 19081913”. In: VI Anuario de Investigaciones. Buenos Aires, Facultad de Psicologia-UBA, 1998.

RIVOREDO, Carlos Roberto Soares Freire de. Por uma história de uma dor: mentalidades médicas, neonatologistas e a dor em recém-nascidos. Campinas, 1996. Tese (Doutorado) Universidade Estadual de Campinas. Faculdade de Ciências Médicas.

ROSE, Nikolas. "Calculable minds and manageable individuals". In: History of the Human Sciences, v.1., n.2, october 1988, pp.179-200.

ROSEN, George. Uma história da saúde pública. São Paulo, Hucitec, 1994.

ROUSSEAU, Jean Jacques. Discurso sobre a origem e os fundamentos da desigualdade entre os homens. São Paulo, Abril Cultural, 1983 (Os pensadores).

SALLA, Fernando. As prisões em São Paulo. 1822-1940. São Paulo, Anablume/Fapesp, 1999.

SALOMON-BAYET, Claire. "Jean-Jacques Rousseau”. In: Châtelet, François (org.). História da filosofia. O Iluminismo. O século XVIII. $2^{\mathrm{a}}$. ed., Rio de Janeiro, Zahar, 1982.

SANTOS FILHO, Lycurgo de Castro. História geral da medicina brasileira. São Paulo, Hucitec/Edusp, 1991. 2 volumes.

SCHWARCZ, Lilia Moritz. O espetáculo das raças. Cientistas, instituições e questão racial no Brasil 1870-1930. São Paulo, Companhia das Letras, 1993.

SCHWARTZ, Roberto. Um mestre na periferia do capitalismo. Machado de Assis. $2^{\mathrm{a}}$ ed. São Paulo, Duas Cidades, 1991.

SERRANO, J. Farias Brito. O homem e a obra. Rio de Janeiro, Companhia Editora Nacional, 1939 (Brasiliana).

SEVCENKO, Nicolau. Orfeu extático na metrópole. São Paulo, sociedade e cultura nos frementes anos 20. $2^{a}$ reimpressão, São Paulo, Companhia das Letras, 2000.

SKIDMORE, T.E. Preto no branco. Raça e nacionalidade no pensamento brasileiro. $2^{\mathrm{a}}$ ed. Rio de Janeiro, Paz e Terra, 1976. 
SMITH, Roger. "Does the history of psychology have a subject?". In: History of the Human Sciences, v. 1, n.2, october 1988, pp.147-177.

STEPAN, Nancy. Beginnings of Brazilian science. New York, Science History Publications, 1976.

STEPAN, Nancy. The hour of Eugenics. Race, gender and nation in Latin America. London, Cornell University Press, 1991.

TAYLOR, I., WALTON, P. e YOUNG, J. La nueva criminologia. Contribución a una teoria social de la conducta desviada. Buenos Aires, Amorrortu, 1997.

TOTH, Stephen. "Desire and the delinquent: juvenile crime and deviance in fin-de-siècle French criminology”. History of the Human Sciences v.10 n.4, 1997, pp.45-63.

UCHOA, Darcy de Mendonça. Organização da psiquiatria no Brasil. São Paulo, Sarvier, 1981.

VIANNA, Adriana de Resende B. O mal que se adivinha. Polícia e menoridade no Rio de Janeiro, 1910-1920. Rio de Janeiro, Arquivo Nacional, 1999.

ZIZEK, Slavoj (ORG.) Um mapa da ideologia. Rio de Janeiro, Contraponto, 1996. 